\title{
Strategi Bimbingan Islam Tokoh Agama di Bangka Belitung: Kontestasi dalam Masyarakat Pedesaan
}

\author{
Rozi \\ Program Studi Interdisciplinary Islamic Studies, Pascasarjana UIN Sunan Kalijaga \\ Yogyakarta, Indonesia \\ rozielfaqirilmi@gmail.com
}

\begin{abstract}
The paper aims to describe the strategies of the Old Teacher and Ustaz Muda in providing Islamic guidance to the people of Kayu Besi Village, Puding Besar District, Bangka Regency, Bangka Belitung Islands, examining the contestation that was carried out by both to gain community legitimacy, and to analyze the extent to which the contestation of the two religious figures in Bangka Belitung. This research is a qualitative research. As for data collection techniques, the authors used in-depth interviews to obtain data in the field. The interview was conducted faceto-face and the questions were spontaneous according to what the writer saw, heard and felt in the field. The author interviewed several religious figures, 30 people in Kayu Besi Village, 20 teenagers, fathers, mothers, community leaders, the two religious leaders who were the focus of the research, as many as 40 guidance members. The author also conducts participatory observations to explore and observe data in the field. Then the authors documented as reinforcing data to be used as arguments and apologies for the research results. The results showed that in providing Islamic guidance to the community, Guru Tua was not just giving religious advice. However, he also provides assistance to various problems faced by members of the guidance and village community, both personal, family, social, and especially religious issues. Meanwhile, the provision of Islamic guidance carried out by Ustaz Muda was only limited to giving religious advice or it could be said by recitation. Guidance is given not to touch aspects of community life. In the sense that it does not solve problems for problems that develop in life, either individuals or groups of people. In addition, in providing Islamic guidance to rural communities, the two of them are contesting each other to gain community legitimacy. The contestation is real. There are three forms of contestation that occur in both of them, namely: First, the contestation of wisdom. Second, power contestation. Third, ideological contestation. At the end of the contestation story, the Old Teacher received more legitimacy from the community for his character. Meanwhile, Ustaz Muda lost legitimacy from the community, so he tried to return to build that legitimacy.
\end{abstract}

Keywords; Islamic Guidance Strategy, Religious Figures, Contestation, Rural Communities

\begin{abstract}
Abstrak
Penelitian ini bertujuan untuk mendeskripsikan strategi Guru Tua dan Ustaz Muda dalam memberikan bimbingan Islam kepada masyarakat Desa Kayu Besi, Kecamatan Puding Besar, Kabupaten Bangka, Kepulauan Bangka Belitung, menelaah kontestasi yang dilakukan keduanya untuk mendapatkan legitimasi masyarakat, dan menganalisis sejauh mana kontestasi kedua tokoh agama tersebut di Bangka Belitung. Penelitian ini adalah penelitian kualitatif. Adapun teknik pengumpulan data, penulis menggunakan wawancara mendalam untuk memperoleh data di lapangan. Wawancara tersebut dilakukan dengan cara bertatap muka dan pertanyaan bersifat spontan disesuaikan dengan apa yang dilihat, didengar, dan dirasakan oleh penulis di lapangan. Penulis mewawancarai beberapa tokoh agama, masyarakat Desa Kayu Besi sebanyak 30 orang, remaja 20 orang, bapak-bapak, ibu-ibu, tokoh masyarat, kedua tokoh agama yang menjadi fokus penelitian, anggota bimbingan sebanyak 40 orang. Penulis juga melakukan observasi partisipasi untuk mendalami dan mengamati data di lapangan. Kemudian penulis melakukan dokumentasi sebagai data penguat untuk dijadikan
\end{abstract}


Mawa'izh

Jurnal Dakwah dan Pengembangan Sosial Kemanusiaan

Vol. 11, no. 2 (2020), pp. 301-357.

DOI: https://doi.org/10.32923/maw.v11i2.1442

argumentasi dan apologi pada hasil penelitian. Hasil penelitian menunjukkan bahwa dalam memberikan bimbingan Islam kepada masyarakat, Guru Tua tidak hanya sekadar memberikan nasihat keagamaan. Namun dia juga melakukan pemberian bantuan terhadap pelbagai permasalahan yang dihadapi oleh anggota bimbingan dan masyarakat desa, baik permasalahan bersifat pribadi, keluarga, sosial, dan khususnya agama. Sedangkan pemberian bimbingan Islam yang dilakukan oleh Ustaz Muda, hanya sebatas pemberian nasihat keagamaan atau dapat dikatakan dengan pengajian. Bimbingan diberikan tidak sampai menyentuh aspek kehidupan masyarakat. Dalam artian bahwa tidak melakukan penyelesaian masalah atas permasalahan yang berkembang dalam kehidupan, baik individu atau kelompok masyarakat. Selain itu, dalam memberikan bimbingan Islam kepada masyarakat pedesaan, keduanya saling berkontestasi untuk mendapatkan legitimasi masyarakat. Kontestasi dilakukan secara nyata. Ada tiga bentuk kontestasi yang terjadi pada keduanya, yaitu: Pertama, kontestasi kealiman. Kedua, kontestasi kuasa. Ketiga, kontestasi ideologi. Akhir kisah kontestasi tersebut, Guru Tua mendapatkan semakin banyaknya legitimasi dari masyarakat atas ketokohannya. Sedangkan Ustaz Muda kehilangan legitimasi dari masyarakat, sehingga dirinya berusaha kembali untuk membangun legitimasi tersebut.

Kata Kunci: Strategi Bimbingan Islam, Tokoh Agama, Kontestasi, Masyarakat Pedesaan

Received: 29-10-2020; accepted: 12-11-2020; published: 10-12-2020

Citation: Rozi, 'Strategi Bimbingan Islam Tokoh Agama di Bangka Belitung: Kontestasi dalam Masyarakat

Pedesaan', Mawa'izh: Jurnal Dakwah dan Pengembangan Sosial Kemanusiaan, vol. 11, no. 2

(2020), pp. 217-272. 


\section{A. PENDAHULUAN}

Wacana keislaman pada masyarakat pedesaan saat ini tidak dapat dipisahkan dari peran tokoh agama dalam memberikan bimbingan Islam. Tokoh agama adalah aktor yang mampu memainkan peran penting dalam kehidupan masyarakat. Kehadiran mereka di tengah masyarakat memiliki pengaruh besar dan dipandang sangat penting. ${ }^{1}$ Terlebih kontribusi mereka dalam memberikan bimbingan Islam. Tidak jarang pula sikap mereka dijadikan oleh masyarakat sebagai teladan. ${ }^{2}$ Wawasan pengetahuan keagamaan yang luas turut menjadikan mereka sangat dipercayai oleh masyarakat. Mereka juga dianggap mumpuni untuk membantu menyelesaikan pelbagai permasalahan masyarakat, baik masalah pribadi, keluarga, dan sosial, khususnya agama.

Penghormatan diberikan kepada para tokoh agama (baca: ulama), sebab mereka memiliki otoritas keagamaan, sehingga kehadiran mereka dianggap mampu menyelesaikan pelbagai problem. Otoritas mereka terbangun karena dipandang sebagai pewaris para nabi. Oleh sebab itu, mereka menduduki tempat yang penting di tengah kehidupan masyarakat yang beragama Islam. ${ }^{3}$ Tidak hanya itu, ketokohan mereka diakui juga turut terbentuk dari pendidikan agama yang melatarbelakanginya, baik dari lembaga pendidikan seperti perguruan tinggi Islam, pesantren, ataupun lembaga pendidikan keislaman lainnya. ${ }^{4}$ Dengan demikian, pemahaman tokoh agama tidak hanya sekadar cakupan ketauhidan (theology), moralitas (morality), dan fikih. ${ }^{5}$ Namun hal itu mencakup pengetahuan yang lebih luas, seperti ritual keagamaan (religious rituals) dan praktik dalam peribadatan. Tokoh agama dalam konteks ini juga dapat diistilahkan sebagai religious leaders.

Religious leaders adalah pakar dan praktisi yang dituntut memiliki latar belakang pendidikan yang jelas, serta terlibat aktif dalam kegiatan masyarakat. Hal itu dikarenakan selain tokoh agama dapat membimbing masyarakat, juga berpotensi menjerumuskan kepada konflik dalam beragama. ${ }^{6}$ Religous leaders dalam perbincangan ini adalah tokoh agama yang berperan dalam memberikan bimbingan Islam kepada masyarakat yang berada di pedesaan.

Dalam memberikan bimbingan Islam kepada masyarakat di pedesaan, ${ }^{7}$ seorang tokoh agama dituntut untuk memiliki wawasan keilmuan yang luas dan dibarengi dengan

\footnotetext{
${ }^{1}$ Peran tokoh agama dalam pemberian bimbingan Islam sebagai upaya pembentukan manusia untuk mengamalkan dan menghayati ajaran agama dalam kehidupan sehari-hari, baik kehidupan pribadi ataupun sosial masyarakat. Oleh sebab itu, terbangunnya kesadaran manusia dalam kepribadian dan masyarakat dapat menimbulkan rasa bertanggung jawab atas bangsanya. Lihat Anas Shalahuddin, Bimbingan dan Konseling (Bandung: CV Pustaka Setia, 2010), 99.

2 Malik Bin Nabi, Membangun Dunia Baru Islam (Bandung: Mizan, 1994), 36.

3 Ro'fah dan Eva Latipah, "Strategi Bertahan dan Aktivitas Pendidikan Islam di Kawasan Minoritas", kontributor, Ulama dan Negara-Bangsa: Membaca Masa Depan Islam Politik di Indonesia (Yogyakarta: PusPIDeP, 2019), 213 - 214.

${ }^{4}$ Perlu dipahami bahwa corak pemikiran seorang tokoh agama, berperilaku, dan bersikap turut dipengaruhi oleh pendidikannya. Sederhananya, wawasan yang luas dan pengetahuan yang mendalam tergantung tinggi rendahnya pendidikan seorang tokoh agama. Jika dibandingkan dengan tokoh agama yang berpendidikan rendah, maka kedewasaan berpikir dan pemahaman keagamaan yang mendalam, serta luas dapat dipastikan dimiliki oleh tokoh agama yang berpendidikan tinggi. Lihat Ro'fah dan Eva Latipah, “Strategi ...", 215.

${ }^{5}$ Noorhaidi Hasan dan Anas Aijudin, "Islam dan Kekuasaan: Menakar Pandangan Ulama Surakarta terhadap Negara-Bangsa", Ibnu Burdah, Najib Kailani, dan Munirul Ikhwan (ed.), Ulama, Politik, dan Narasi Kebangsaan: Fragmentasi Otoritas Keagamaan di kota-kota Indonesia (Yogyakarta: PusPIDep, 2019), 4.

${ }^{6}$ Nukhet A. Sandal, Religious Leaders and Conflict Transformation: Northern Ireland and Beyond (United Kingdom: Cambridge University Press, 2017), 2.

${ }^{7}$ Masyarakat pedesaan ditandai dengan pemilik ikatan perasaan batin yang kuat antar sesama warga desa, yaitu perasaan setiap warga/anggota masyarakat yang amat kuat hakikatnya, bahwa seseorang merasa merupakan bagian yang tidak dapat dipisahkan dari masyarakat di mana pun ia hidup dicintai serta
} 
pengalaman yang matang. Sehingga hal tersebut memungkinkan mereka mendapatkan legitimasi dari masyarakat dan dipercayai untuk membimbing mereka. Oleh sebab itu, tidak dimungkiri bahwa untuk mendapatkan legitimasi masyarakat berindikasi terjadinya kontestasi di kalangan tokoh agama. Inilah yang disebut Antje Wiener bahwa salah satu adanya kontestasi adalah untuk mendapatkan legitimasi atau pengakuan dari orang lain terhadap dirinya. ${ }^{8}$ Adapun hasil dari kontestasi tersebut menentukan konfigurasi otoritas keagamaan tokoh agama dengan segala karakteristik yang melingkupinya. Meminjam istilah Virginia Satir (1967) bahwa dalam diri seorang pemimpin yang memberikan bimbingan, dalam konteks ini adalah tokoh agama setidaknya harus memiliki dua karakteristik: Pertama, resource person. Kedua, model of communication..$^{9}$ Dengan demikian, maka setidaknya tokoh agama harus memiliki characteristics tersebut untuk mendapatkan legitimasi masyarakat.

Dalam masyarakat pedesaan, religious leaders juga adalah pembimbing. Banyak tokoh agama berprofesi sebagai pembimbing. Mereka dikenal sebagai ustaz, guru, dan kiai. Panggilan tersebut ditujukan bagi orang yang memiliki keahlian dalam bidang ilmu keagamaan. Sehingga tidak jarang masyarakat meminta mereka untuk memberikan bimbingan.

Penelitian ini dilaksanakan di Desa Kayu Besi, Kecamatan Puding Besar, Kabupaten Bangka, Provinsi Kepulauan Bangka Belitung. Desa tersebut memiliki beberapa orang yang dianggap sebagai tokoh agama, yaitu Ustaz M. A, Ustaz Y, Ustaz M. S, Ustaz T, Ustaz Muda, dan Guru Tua. Meskipun demikian, dari beberapa tokoh agama tersebut, yang memberikan bimbingan kepada masyarakat adalah Guru Tua (nama disamarkan) dan Ustaz Muda (nama disamarkan).

Dipilihnya Guru Tua dan Ustaz Muda sebagai subjek penelitian lapangan (field research) dalam kajian ini didasarkan beberapa alasan. Berbeda dengan beberapa tokoh agama yang lain, kedua tokoh agama inilah yang dipercayai masyarakat untuk memberikan bimbingan Islam di desa tersebut. Otoritas yang dibangun keduanya memiliki keunikan tersendiri. Sehingga keduanya menunjukkan eksistensinya guna mendapatkan legitimasi masyarakat.

Guru Tua mulai memberikan bimbingan Islam kepada masyarakat desa dari tahun 1988 - sekarang. Kealiman dan pengalamannya dalam membimbing masyarakat tidak bisa diragukan lagi. Otoritasnya telah terbangun dari sejak muda. Masyarakat pun mengenal baik dirinya. Guru Tua sangat disegani dan dipercayai masyarakat dalam membimbing mereka. Bahkan, tidak jarang masyarakat memintanya untuk memberikan bimbingan atas masalah yang mereka alami, baik individu, keluarga, sosial kemasyarakatan, dan agama. Dalam pelaksanaan kegiatan bimbingannya, Guru Tua menyuguhkan materi tentang ketauhidan, fikih, tasawuf, dan akhlak. Akan tetapi, dalam kegiatan bimbingan yang dilaksanakan tidak

mempunyai perasaan bersedia untuk berkorban setiap waktu demi masyarakat atau anggota masyarakat, karena beranggapan sama-sama sebagai masyarakat yang saling mencintai dan saling menghormati, mempunyai hak tanggung jawab yang sama terhadap keselamatan dan kebahagiaan bersama di dalam masyarakat. Lihat Soerjono Soekanto, Sosiologi Suatu pengantar (Jakarta: Rajawali, 2009), 76.

${ }^{8}$ Antje Wiener, A Theory of Contestation (New York: Springer, 2014), 7.

9 Resource person merupakan seseorang yang memiliki wawasan yang luas terkait informasi yang berkembang dan tidak menutup informasi tersebut di hadapan jemaahnya. Sedangkan model of communication adalah seseorang yang memiliki komunikasi yang baik, pendengar yang baik dan terampil. Pembimbing juga tidak boleh merasa pintar dan paling benar, serta mencari ketenaran pribadi. Pembimbing harus mampu bersikap menghargai pendapat orang lain. Lihat Sofyan S. Willis, Konseling Individual: Teori dan Praktek (Bandung: Alfabeta, 2007), 79. 
hanya sekadar memberikan materi, namun juga melakukan kegiatan konseling atas permasalahan yang berkembang di masyarakat. ${ }^{10}$

Selanjutnya adalah Ustaz Muda. Dia berasal dari Bangkalan, Madura pada tahun 2007. Ustaz Muda merupakan sosok ustaz yang memiliki semangat tinggi dalam memberikan bimbingan Islam. Hal itu terlihat dari kegiatannya yang disibukkan dalam membimbing masyarakat. Kedatangannya ke Bangka Belitung, berawal dari kegiatan pengiriman guru tugas dari Pondok Pesantren Syaikhona Cholil Bangkalan, Madura. Awalnya Ustaz Muda ditempatkan di Desa Kimak, Kecamatan Merawang, Kabupaten Bangka. Namun dalam kurun waktu tiga bulan, dirinya tidak betah dan meminta untuk pulang ke Madura. Ketidakbetahan tersebut dikarenakan ketidakjelasan pihak Yayasan Pondok Pesantren Ilzamun Maju Bahrin dalam membuat laporan ke Pondok Pesantren Syaikhona Cholil Bangkalan. Di mana, dalam laporan tersebut dikatakan bahwa sudah ada Madrasah Ibtidaiyah, Tsanawiyah, dan Aliyah, akan tetapi ternyata belum ada satu pun dan santrinya pun belum ada. Oleh sebab itu, Ustaz Muda tidak betah dan memilih untuk pulang ke Madura. Mendengar hal tersebut, maka Ustaz Muda diminta Guru Tua untuk tinggal di Desa Kayu Besi, Kecamatan Puding Besar, Kabupaten Bangka. ${ }^{11}$

Mendengar permintaan dari Guru Tua, akhirnya Ustaz Muda bersedia untuk tinggal di desa tersebut dan mengurungkan niatnya untuk pulang ke Madura. Guru Tua pun mengenalkan Ustaz Muda kepada masyarakat dan meminta kepada mereka untuk menerima kehadiran Ustaz Muda. Masyarakat pun menerima dengan senang hati dan meminta kepada Ustaz Muda untuk membimbing mereka. Hubungan Guru Tua dan Ustaz Muda pun terjalin akrab. Keduanya sama-sama dalam memberikan bimbingan Islam kepada masyarakat.

Setelah beberapa tahun kemudian, Ustaz Muda pun mulai dikenal oleh banyak orang. Terlebih ketika dirinya bergabung di organisasi Front Pembela Islam (FPI) pada tahun 2012, dan dia merupakan ketua Dewan Pimpinan Pusat (DPP) wilayah Bangka Belitung. Bergabungnya Ustaz Muda ke FPI, membuat hubungan antara Guru Tua dengannya mulai tidak akrab. Ketidakakraban tersebut dimulai ketika Guru Tua sedang menjadi khotib Jum'at dinyatakan tidak sah oleh Ustaz Muda dan diwajibkan untuk menggantinya pada sholat Zuhur. Namun, pernyataan Ustaz Muda tersebut tidak dilandaskan dengan alasan. Hal itu pun membuat masyarakat terkejut sekaligus bingung, karena harus mengikuti siapa. Namun, beberapa masyarakat menanyakan hal itu kepada Guru Tua terkait apakah mereka harus mengulang dengan sholat Zuhur atau tidak. Mendengar pertanyaan dari masyarakat, Guru Tua pun menyikapi dengan bijak. Di mana dia mengatakan kepada masyarakat, apabila masyarakat meyakini bahwa khotbah tidak sah, maka silahkan menggantikan dengan sholat Zuhur. Guru Tua tidak ingin adanya perselisihan di masyarakat, terlebih hal itu sedang berada di masjid. Mendengar ucapan Guru Tua tersebut, maka masyarakat pun meyakini bahwa khotbah tetap sah. Alhasil, sholat Zuhur hanya dilaksanakan oleh Ustaz Muda dan beberapa santri yang mempercayainya. ${ }^{12}$

Dari paparan singkat di atas, dapat dipahami bahwa kedua tokoh agama tersebut memiliki keunikan tersendiri untuk mendapatkan legitimasi. Meskipun demikian, jika ditangkap secara pandangan akademisi, maka disitulah terkadang adanya kontestasi. Kontestasi untuk merebut pengakuan dari masyarakat terjadi sebab pengakuan tersebut mampu membuat tokoh agama untuk selalu menunjukkan eksistensi. Oleh sebab itu, untuk memberikan bimbingan Islam kepada masyarakat pedesaan, tokoh agama harus mampu mengemas

${ }^{10}$ Observasi pada tanggal 15 - 18 Desember 2019.

11 Observasi pada tanggal 13 - 17 Desember 2019.

12 Wawancara kepada beberapa masyarakat Desa Kayu Besi, 12 - 18 Desember 2019. 
pesan-pesan bimbingan dan memiliki strategi yang sekiranya mampu mendapatkan legitimasi masyarakat.Dari latar belakang yang telah dijelaskan di atas, diskursus ini berusaha menjawab persoalan yang ada. Penulis merumuskan masalah sebagai berikut: Bagaimana strategi Guru Tua dan Ustaz Muda dalam memberikan bimbingan Islam kepada masyarakat pedesaan? Bagaimana kontestasi antara Guru Tua dan Ustaz Muda dalam memberikan bimbingan Islam untuk mendapatkan legitimasi masyarakat pedesaan? Mengapa kontestasi antara Guru Tua dan Ustaz Muda selaku tokoh agama dalam memberikan bimbingan Islam kepada masyarakat pedesaan terjadi?

\section{Kajian Pustaka}

Diskursus tentang tokoh agama dan peran pentingnya dalam kehidupan masyarakat memang selalu menarik untuk dikaji. Hal tersebut dikarenakan kajian Islam pada masyarakat Islam pedesaan tidak dapat dipisahkan dari peranan penting para tokoh agama dalam memberikan bimbingan Islam. Adapun penelitian-penelitian yang telah dilakukan, dicantumkan penulis berdasarkan beberapa tema yang mengkaji tokoh agama.

Ada studi tentang peran tokoh agama dalam kehidupan keberagamaan masyarakat seperti penelitian yang dilakukan oleh Ibnu Sakdan, yang menempatkan tokoh agama sebagai penyuluh agama untuk meningkatkan kesadaran masyarakat. Penelitiannya menunjukkan bahwa peran tersebut berjalan tidak optimal. Hal itu disebabkan beberapa faktor, yaitu: tokoh agama memiliki tugas pribadi yang harus dilaksanakan dengan baik, kurangnya dukungan dan biaya dari pihak pemerintah untuk kehidupan sehari-hari mereka, adanya perbedaan pendapat terkait pemahaman agama dan adat istiadat, terbatasnya tenaga penyuluh dan luasnya wilayah kerja, kurangnya sosialisasi tentang agama kepada masyarakat, serta sebagian masyarakat tidak menerima kehadiran para penyuluh ke tempat mereka. ${ }^{13}$ Sementara Widayat Sulistyanto ${ }^{14}$ menjelaskan bahwa para tokoh agama berperan aktif dalam membangun kehidupan masyarakat. Sejak awal para tokoh agama telah mendorong terjadinya perubahan sosial. Dengan menggunakan lensa yang serupa, Supartini 15 menempatkan tokoh agama sebagai tokoh infomatif, edukatif, konsultatif, dan advokatif. Dengan menggunakan lensa yang serupa, Khusnul Khotimah ${ }^{16}$ menempatkan posisi tokoh agama sebagai pemimpin keagamaan. Dia menjelaskan bahwa tokoh agama berperan penting dalam pengembangan sosial keagamaan, seperti pendidikan, sosial keagamaan, politik, dan dakwah. Dengan menggunakan lensa yang serupa, Piyantoro ${ }^{17}$ menempatkan peran tokoh agama dalam merajut pluralitas yaitu membimbing umat, memberikan contoh tauladan, saling tolong menolong, gotong royong, dan menyampaikan

13 Ibnu Sakdan, 2017, “Optimalisasi Peran Tokoh Agama dalam Meningkatkan Kesadaran Beragama Masyarakat di Kecamatan Kuala, Kabupaten Nagan Raya”, Skripsi: Fakultas Dakwah dan Komunikasi UIN ArRaniry, dalam https://repository.ar-raniry.ac.id/329/, diakses 12 Desember 2019.

14 Widayat Sulistyanto, 2007, "Peranan Tokoh Agama dalam Perubahan Sosial Komunitas Pemulung di Kampung Sidomulyo, Kecamatan Tegalrejo Kodya, Yogyakarta:, Skripsi: UIN Sunan Kalijaga Togyakarta, dalam http://digilib.uin-suka.ac.id/36136/ diakses 23 Desember 2019.

15 Supartini, 2018, "Peran Tokoh Agama dalam Meningkatkan Sikap Keberagamaan Masyarakat di Dusun Pucung, Desa Sendang, Ngrayun, Ponorogo", dalam http://etheses.iainponorogo.ac.id/4399/1/pdfjoiner.pdf. diakses 12 Desember 2019.

16 Khusnul Khatimah, 2015, "Peran Tokoh Agama dalam Pengembangan Sosial Agama di Banyumas: Studi Historis Sosiologis Tokoh Agama Abad 21", dalam http://repository.iainpurwokerto.ac.id/345/1/khusnul\%20khotimah_PERAN\%20TOKOH\%20AGAMA\%20D ALAM\%20PENGEMBANGAN\%20SOSIAL\%20AGAMA.pdf., diakses 12 Desember 2019.

17 Piyantoro, 2017, "Peran Tokoh Agama dalam Merajut Pluralitas: Studi Kasus Tokoh Agama Islam Kecamatan Kartasura”, dalam http://eprints.ums.ac.id/55794/, diakses 12 Desember 2019. 
dakwah dengan hikmah. Dengan lensa yang serupa, Supriyanto ${ }^{18}$ menempatkan tokoh agama sebagai penyuluh agama. Peran tokoh agama dilakukan melalui kegiatan keagamaan seperti tahlilan dan pengajian. Dengan menggunakan lensa yang serupa, Sulis Rahmawanto ${ }^{19}$ menempatkan tposisi tokoh agama sebagai seorang yang dapat menyatupadukan pendapat yang berbeda di kalangan masyarakat. Dengan menggunakan lensa yang serupa, Ismutadi 20 menempatkan tokoh agama sebagai orang yang mampu membina etika Islam pada masyarakat, khususnya generasi muda dengan mengadakan kegiatan-kegiatan pengajian seperti pengajian yasinan yang dilaksanakan pada malam Jumat, pelaksanaan kegiatan ibadah, dan ceramah agama. Dengan lensa yang serupa, Karimi Toweren ${ }^{21}$ menunjukkan peran tokoh agama hanya terbatas pada kegiatan umum di masyarakat, seperti salat Jumat, mengajar istri aparat desa pada Jumat pagi, membaca Yasin, dan memberikan pengarahan. Dengan lensa yang serupa, Kemas Muhammad Gemilang22 menunjukkan bahwa para tokoh agama telah memberikan manfaat sebagaimana yang tersirat dalam Al-Qur'an dan perundang-undangan, serta telah membantu pemerintah Indonesia dalam mewujudkan masyarakat yang melestarikan ikatan perkawinan, makmur, dan sejahtera. Studi peran tokoh agama dalam kehidupan keberagamaan masyarakat ini, menambah konteks berharga untuk studi kontemporer saya ini.

Berbeda dengan lensa penelitian di atas, penelitian lain fokus pada kancah peran tokoh agama dalam dunia perpolitikan. Dalam hal perpolitikan, Ujang Mahadi ${ }^{23}$ menjelaskan bahwa terdapat tiga tipologi politik tokoh agama, yaitu: politisi religius, politisi nasionalis, dan politisi dakwah. Sementara Ulin Nuha ${ }^{24}$ menjelaskan bahwa berbagai taktik dan strategi tokoh agama dalam menjalankan kampanye politik, partai politik yang berperan mengambil suara masyarakat. Sementara Bahaudin Amrulloh ${ }^{25}$ menjelaskan hukum Islam selalu mengatur hubungan antara manusia dan negara, serta mementingkan kemaslahatan dan menghilangkan ke-mudharat-an. Sementara Arif Sofianto ${ }^{26}$ menjelaskan bahwa nilai-nilai agama menjadi landasan dan rujukan dalam menilai figur politik yang baik dan buruk, tanpa

18 Supriyanto, 2016, "Peran Tokoh Agama dalam Dinamika Pembangunan Masyarakat di Desa Ketanonageng Kecamatan Sragi Kabupaten Pekalongan”, dalam https://lib.unnes.ac.id/27468/ diakses 13 Desember 2019.

${ }^{19}$ Sulis Rahmawanto, 2016, "Peran Tokoh Agama dalam Mewujudkan Keteraturan Masyarakat", dalam https://www.researchgate.net/publication/330660605_

AGAMA_DALAM_MEWUJUDKAN_KETERATURAN_MASYARAKAT, diakses 13 Desember 2019.

20 Ismutadi, 2018, "Penerapan Etika Islam dalam Pembangunan Masyarakat: Studi Kepemimpinan Tokoh Agama di Desa Bandar Agung”, dalam http://repository.radenintan.ac.id/3416/1/Ismutadi.pdf, diakses 13 Desember 2019.

21 Karimi Toweren, 2018, "Peran Tokoh Agama dalam Peningkatan Pemahaman Agama Masyarakat Kampung Toweren Aceh Tengah”, DAYAH: Journal of Islamic Education, UIN Ar-Raniry, Vol. 1, No. 2, 2018, 258 -272 .

22 Kemas Muhammad Gemilang, 2015, "Peran Tokoh Agama dalam Pembentukan Keluarga Sakinah di Kelurahan Kricak, Kecamatan Tegalrejo, Kota Yogyakarta”, Skripsi, UIN Sunan Kalijaga Yogyakarta, dalam http://digilib.uin-suka.ac.id/17177/. diakses 13 Desember 2019.

23 Ujang Mahadi, 2015, "Komunikasi Politik Kiai pada Kampanye Pemilu”, ADDIN: Media Dialektika Ilmu Islam, IAIN Kudus, Vol. 9, No. 2, (2015).

${ }^{24}$ Ulin Nuha, "Peran Politik Kiai dalam Proses Politik di Partai Politik: Studi Kasus Peran KH. A. Haris Shodaqoh di Partai Persatuan Pembangunan", dalam https://media.neliti.com/media/publications/160785ID-peran-politik-kiai-dalam-proses-politik.pdf diakses 23 Desember 2019.

25 Bahaudin Amrullah, 2015, "Peran Kiai dalam Politik: Studi Atas Pemenangan Calon Legislatif oleh KH. Arsyad Bushoiri dalam Perspektif Hukum Islam”, Skripsi: IAIN Tulungagung, dalam http://repo.iaintulungagung.ac.id/2746/. diakses 23 Desember 2019.

${ }^{26}$ Arif Sofianto, "Peran Agama Terhadap Perilaku Pemilih dalam Pemilu Legislatif 2014 di Jawa Tengah", Analisa Journal of Social Science and Religion, Vol. 22, No. 02 (Desember 2015), 161 - 172. 
melihat latar belakang partai dan ideologinya. Pemilih dipengaruhi oleh pertimbangan rasionalitas diri sendiri dibanding tokoh dan organisasi agama. Dengan menggunakan lensa yang serupa, Jhon L. Kallerson Chaplain ${ }^{27}$ menjelaskan bahwa keterlibatan strategis para tokoh agama membuat tantangan baru yang dihadapi oleh pemerintah Kombatan, karena keterlibatan mereka akan berisiko dalam pelaksanaan pemerintahannya. Berbeda halnya dengan Jennifer L. Epley ${ }^{28}$ yang menyelidiki hubungan antara karisma dan kepemimpinan di Indonesia atau negara tertentu dapat menawarkan wawasan untuk mengklarifikasi konsep politik tertentu dan membentuk pembangunan teori masa depan, pengumpulan data, dan pengujian. Sementara Abd. Hannan ${ }^{29}$ menjelaskan bahwa tokoh agama mimiliki fungsi besar dalam menjelaskan dinamika dan arah sosio-politik Madura ke depan. Sementara Huma Haider ${ }^{30}$ menjelaskan bahwa literatur sangat terbatas membicarakan tentang peran para pemimpin agama dalam melawan pemilihan dan kekerasan politik. Terlebih lagi cara melibatkan para pemimpin dalam mengambil peran itu. Artikel tersebut menarik pada literatur yang membahas keterlibatan aktor agama secara lebih umum. Sementara Fahrur Rozi Jamil ${ }^{31}$ menjelaskan kekarismaan dan kekuasaan tokoh agama dapat membuat masyarakat mematuhinya, sehingga dalam perpolitikan tokoh agama sangat diuntungkan dengan pengakuan dan ketundukan masyarakat kepadanya. Dengan menggunakan lensa serupa, M. Iqbal Ahnaf dan Danielle N. Lussier ${ }^{32}$ menjelaskan bahwa berdasarkan analisis isi khotbah di 12 Masjid dan Gereja pada bulan sebelum pemilihan, mereka mengidentifikasi tiga faktor yang membuat para pemimpin agama tidak mau menggunakan peluang untuk mengintensifkan ketegangan agama. Faktor tersebut yaitu: Pertama, elit tidak termotivasi untuk memperburuk ketegangan komunal karena mereka tidak merasa pemilu akan membawa reformasi atau perubahan yang akan secara serius memengaruhi posisi mereka yang mapan. Kedua, meskipun pesan sektarian dimungkinkan, elit tidak percaya massa dapat dengan mudah dibujuk oleh pesan-pesan politik sektarian. Ketiga, kalah bersaing politik dengan menggunakan pesan-pesan sektarian akan berisiko menghadapi budaya harmoni dominan lokal. Temuan tersebut menunjukkan bahwa beberapa faktor perlu diaktifkan untuk para pemimpin agama guna menjalankan otoritas moral mereka atas penyembah untuk tujuan politik. Kehadiran struktur peluang untuk mengintensifkan konflik sektarian tidak cukup untuk memunculkan konflik itu.

27 Jhon L. Kallerson Chaplain, 2014, “National Strategy for Religious Leader Engagements: Interagency Challenges Supporting Combatant Commands", dalam https://www.iwp.edu/national-strategy-for-religiousleader-engagements-interagency-challenges-supporting-combatant-comma nds-2/. diakses 23 Desember 2019.

28 Jennifer L. Epley, “Weber's Theory of Charismatic Leadership: The Case of Muslim Leaders in Contemporary Indonesian Politics", International Journal of Humanities and Social Science, Vol. 5, No. 7, (July 2015).

${ }^{29}$ Abd. Hannan, “Agama, Kekerasan, dan Kontestasi Politik Elektoral: Penggunaan Simbol Keagamaan Kiai dan Kekuasaan Blater dalam Pertarungan Politik Lokal Madura”, Jurnal Sosiologi Agama, Fakultas Ushuluddin dan Pemikiran Islam UIN Sunan Kalijaga Yogyakarta, Vol. 12, No. 2 (2018).

${ }^{30}$ Huma Haider, "Religious Leaders and the Prevention of Electoral Violence", GSDRC Helpdesk Research Report 1366, University of Birmingham, (May 2016).

31 Fahrur Rozi Jamil, 2010, "Kharisma Tokoh dan Kekuasaan Politik: Studi Kasus RKH Fuad Amin Imron dalam Pilkada Bangkalan tahun 2008”, Skripsi: UIN Sunan Kalijaga Yogyakarta, dalam http://digilib.uinsuka.ac.id/4044/ diakses 24 Desember 2019.

32 M. Iqbal Ahnaf dan Danielle N. Lussier, "Religious Leaders and Elections in the Polarizing Context of Indonesia”, Jurnal Humaniora, Vol. 31, No. 3 (October 2019), 227 - 237. 
Berbeda dengan fokus di atas, penelitian yang dilakukan oleh Douglas F. Barnes ${ }^{33}$ mengusulkan teori karismatik yang mengeksplorasi kondisi sosial di mana karisma akan muncul. Karismatik para pemimpin dihipotesiskan untuk hidup di masa perubahan sosial yang radikal atau terputus arus utama masyarakat, menganggap tradisi agama sebagai relatif, dan memiliki ajaran inovatif jika agama mereka harus dilembagakan. Sementara Ferry Muhammadsyah Siregar, Nur Kholis Setiawan, dan Robert Setio ${ }^{34}$ menjelaskan bahwa struktur dan pola kepemimpinan kiai dalam pesantren yang masih kuat di mana kiai diposisikan sebagai tokoh utama. Dengan lensa yang serupa Siti Nurjannah ${ }^{35}$ menempatkan tokoh agama sebagai pembina remaja masjid dengan mengajarkan ilmu tajwid dan membaca Al-Qur'an. Otoritas yang dimiliki tokoh agama dimanfaatkan untuk membimbing mereka, namun cukup disayangkan bahwa faktor penghambatnya adalah kurangnya interaksi sosial dan semangat remaja masjid dalam mengikuti kegiatan pembinaan tersebut. Sementara Pauline Hope Cheong ${ }^{36}$ menjelaskan bahwa hubungan antara otoritas keagamaan yang dimediasi dan sosial berubah dalam hal negosiasi media sosial ulama dan komunikasi multimodal kompetensi, dengan implikasi untuk menarik perhatian dan menggembleng jaringan aktif dan sumber daya untuk inisiatif sosial. Sementara Khoirul Minan ${ }^{37}$ menjelaskan bahwa local strongmen yang memiliki fungsi dalam struktur sosial sebagai agen sosial yaitu kiai dan pengusaha. Dalam teori fungsional struktural mereka memiliki fungsi yang besar demi mengembangkan kualitas masyarakat di sekitarnya.

Berbeda dengan penelitian di atas, penelitian yang dilakukan oleh Baharudin dan Moh. Nasikin ${ }^{38}$ menempatkan tokoh agama sebagai pencegah konflik. Dia menjelaskan kondisi kerukunan beragama di Kabupaten Lombok Barat dapat dikategorikan terwujud dengan baik. Lombok Barat setidaknya terdapat 5 agama, yatu: Hindu, Islam, Budha, Kristen Protestan, dan Kristen Katolik. Kelompok mayoritas adalah umat Islam yaitu 86\% (193.722 jiwa), kemudian Hindu, 8,4\% (19.088 jiwa), Budha sebanyak 5,4\% (12.229 jiwa), dan lainlain 0,2 (23 jiwa). Meskipun menduduki potensi terjadinya gesekan dan konflik sosial yang melibatkan agama sangat potensial, namun beberapa tahun terakhir ini gesekan dan konflik sosial yang terjadi di tengah-tengah masyarakat sudah sangat jarang terjadi, karena peran sosial tokoh agama di sana. Dengan lensa yang sama, Ferdian Ardani Putra dan Finish Rimbi Kawindra ${ }^{39}$ menjelaskan bahwa tokoh agama sering kali memberikan jalan terhadap berkembangnya norma kelompok dan nilai-nilai sosial yang sudah terbentuk di masyarakat

33 Douglas F. Barnes, “Charisma and Religious Leadership: An Historical Analysis”, SOURCE: Journal for Scientific Study of Religion, University of Illinois Urbana-Champaign, Vol. 17, No. 1 (Maret 2013), 1 - 18.

34 Ferry Mumamadsyah Siregar, dkk., "Religious Leader and Charismatic Leadership in Indonesia: The Role of Kyai in Pesantren in Java”, KAWISTARA: Jurnal Ilmiah Sosial dan Humaniora, Vol. 3, No. 2 (Agustus 2013), $117-226$.

35 Siti Nurjannah, 2017, "Peran Tokoh Agama dalam Membina Kegiatan Keagamaan Remaja Islam Masjid (Risma) di Desa Sritejo, Kencono, Kota Gajah Lampung Tengah”, Tesis: IAIN Metro, dalam http://repository.metrouniv.ac.id/id/eprint/1738/, diakses 24 Desember 2019.

36 Pauline Hope Cheong, "Religious Leaders, Mediated Authority, and Social Change”, Routledge: Journal of Applied Communication Research, Vol. 39, No. 4 (November 2011), 452 - 454.

37 Khoirul Minan, 2015, "Sinergi Local Strongmen: Pengusaha dan Tokoh Agama dalam Pemilihan Legislatif 2014 di Demak", Tesis: UIN Sunan Kalijaga Yogyakarta, dalam http://digilib.uinsuka.ac.id/16848/. diakses 23 Desember 2019.

38 Baharudin dan Moh. Nasikin, "Peran Sosial Tokoh Agama dalam Merawat Kerukunan Beragama di Lombok Barat", Intutional Repository, Lembaga Penelitian dan Pengabdian Masyarakat, UIN Mataram, (Juli 2018).

${ }^{39}$ Ferdian Ardani Putra dan Finish Rimbi Kawindra, "Komunikasi Tokoh Agama dalam Meredam Konflik Antar Umat Beragama: Studi Agama Islam, Hindu, dan Kristen di Kec. Senduro, Kab. Lumajang”, Prosiding SNasPPM, Vol. 3, No. 1 (2018), 291 - 296. 
berjalan dengan sendirinya. Penyebaran hoax di media sosial yang tak terbendung dengan mudah diakses khalayak, merupakan kendala yang menimbulkan dampak negatif bagi kerukunan umat beragama. Sementara Julsyaf Hanaviah ${ }^{40}$ menjelaskan bahwa proses komunikasi lintas tokoh agama berlangsung secara efektif, karena menggunakan bentuk komunikasi dialogis dan komunikasi kelompok dalam melakukan interaksi sesama pengurus Forum Kerukunan Umat Beragama (FKUB). Sementara Muhammad Adib Baihaqi ${ }^{41}$ menjelaskan bahwa bentuk-bentuk kerukunan umat beragama di Thekelan adalah adanya peran aktif tokoh agama dengan menerapkan prinsip-prinsip komunikasi kelompok dalam bentuk interaksi sosial, bekerja sama, dan memiliki rasa kepedulian terhadap sesama maupun lingkungan yang memiliki kemajemukan agama. Dengan menggunakan lensa yang serupa, Yusuf Faisal $\mathrm{Ali}^{42}$ menjelaskan upaya yang dilakukan para tokoh agama dalam rangka mengembangkan toleransi beragama yaitu melalui dialog antar pemuka agama dan membina pemeluk agamanya masing-masing. Sementara Khairulnizam Mat Karim, Suzy Aziziyana Saili, dan Khadijah Moh. Khambali ${ }^{43}$ menjelaskan bahwa untuk menguji peran tokoh agama Islam di Indonesia melaksanakan dialog antar agama menuju penyelesaian konflik dari perspektif Islam, menjadi dialog internal dan eksternal. Penelitian tersebut membuktikan bahwa Islam mendorong pengikutnya untuk membangun hubungan baik dengan non-Muslim. Dengan menggunakan lensa yang serupa, Fauzi ${ }^{44}$ menjelaskan bahwa ada beberapa hal pencapaian tokoh agama dalam pencegahan konflik yaitu: Pertama, kondisi Aceh masih dirasakan harmonis, meski dengan sedikit dinamis. Kedua, konflik terjadi di antara agama di Aceh pada umumnya disebabkan faktor eksternal, meskipun sebagian kecil dari aspek ekonomi dan sosial budaya. Ketiga, para tokoh agama belum bekerja secara optimal untuk mempertahankan harmonisasi di Aceh. Sementara Suprapto 45 mendeskripsikan sejumlah upaya yang dikembangkan oleh Tuan Guru dan Pedanda dalam rangka bina damai di Lombok, seperti menenangkan jemaah, meredam isu konflik agar massa tidak panik, dan mensosialisasikan nilai-nilai harmoni dalam beragama. Sementara Sofia Hayati ${ }^{46}$ menjelaskan kontestasi terjadi karena masyarakat minoritas yaitu Muslim memprotes terkait pelabelan nama jalan yang mengatasnamakan keagamaan tertentu yaitu Katolik. Hal itu dilakukan sebab masyarakat tidak mendapatkan kemudahan akses untuk membangun tempat ibadah, sehingga masyarakat meminta agar nama jalan tersebut diganti.

\footnotetext{
40 Julsyaf Hanaviah, "Komunikasi Lintas Tokoh Agama dalam Memelihara Kerukunan Umat Beragama: Studi pada Forum Kerukunan Umat Beragama Kabupaten Pesawaran”, dalam http://repository.radenintan.ac.id/4493/1/ SKRIPSI.pdf, diakses 13 Desember 2019.

41 Muhammad Adib Baihaqi, "Peran Tokoh Agama dalam Menjaga Kerukunan Antar Umat Beragama: Komunikasi Kelompok pada Dusun Thekelan, Desa Batur, Kecamatan Getasan, Kabupaten Semarang", dalam http://erepository.perpus.iainsalatiga.ac.id/4402/1/SKRIPSI\%

20LENGKAP\%20ADIB\%20BAIHAQI\%20B.pdf, diakses 12 Desember 2019.

42 Yusuf Faisal Ali, "Upaya Tokoh Agama dalam Mengembangkan Sikap Toleransi Antarumat Beragama”, UCEJ: Untirta Civic Education Journal, Vol. 2, No. 1 (2017).

43 Khairulnizam Mat Karim, dkk., "Role of Religious Leader in Interfaith Dialogue towards Conflict Resolution: An Islamic Perspective”, International Journal of Education and Research, Vol. 2, No. 6 (June 2014), $77-88$.

44 Fauzi, "The Perception of Religious Leaders in Maintaining the Harmonization in Aceh: An Analysis of Siyasah Syar'iyyah", Journal, Universitas Muhammadiyah Metro, Vol 1, No. 2 (June 2017), 18 - 33.

45 Suprapto, "Religious Leaders and Peace Building: The Role of Tuan Guru and Pedanda in Conflict Resolution in Lombok-Indonesia”, Al-Jami'ah: Journal of Islamic Studies, Vol. 53, No. 1 (2015), 225 - 250.

46 Sofia Hayati, 2017, "Kontestasi Ruang Publik: Studi Identitas Kampung Berlabel Agama di Sengkan, Depok, Sleman", Tesis: UIN Sunan Kalijaga Yogyakarta, dalam http://digilib.uin-suka.ac.id/24876/. diakses 23 Desember 2019.
} 
Sementara Al Makin ${ }^{47}$ dalam artikelnya mengeksplorasi konsep negara sekuler yang ditawarkan tiga pemimpin agama di Indonesia, yaitu: seorang imam Katolik, Nicolaus Driyarkara (1913 - 1967), Mukti Ali (1923 - 2004), dan Munawir Sjadzali (1925 - 2004). Ketiga tokoh tersebut mewakili generasi setelah revolusi untuk kemerdekaan Indonesia tahun 1945, dengan mempertahankan legitimasi negara sekuler untuk Indonesia berdasarkan ideologi negara Pancasila.

Berbeda dengan penelitian di atas, penelitian yang dilakukan oleh Health Policy Initiative ${ }^{48}$ menempatkan peran tokoh agama dalam dunia kesehatan. Mereka menjelaskan bahwa Tanzania adalah negara yang sangat religius, dengan mayoritas orang berkomitmen pada Kristen atau Islam. Dalam survei multi-negara tentang keyakinan, 93\% dari Responden Tanzania mengatakan agama sangat penting dalam kehidupan mereka, 80\% melaporkan bahwa mereka menghadiri layanan keagamaan setidaknya setiap minggu satu kali. Dengan otoritas dan pengaruh moral, para pemimpin agama di Tanzania dapat memainkan peran yang kuat dalam menanggapi HIV. Menyadari hal ini, Badan A.S. untuk Pembangunan Internasional mendanai kebijakan Kesehatan Inisiatif di Tanzania (HPI/Tanzania), untuk melibatkan kepercayaan berbasis komunitas dalam mengatasi hambatan utama meningkatkan layanan HIV. Sementara Mark H. Anshel dan Mitchell Smith ${ }^{49}$ menjelaskan bahwa para tokoh agama mempromosikan kebiasaan sehat di antara jemaah. Dengan mengatasi masalah kesehatan, nutrisi, dan kebugaran dari mimbar dan dalam program kegiatan keagamaan. Mereka berkhotbah tentang perlunya hidup sehat. Melalui tindakan tersebut, tokoh agama sebagai agen yang efektif dalam mempromosikan perubahan kritis di bidang kesehatan. Dengan menggunakan lensa yang serupa, Hartini ${ }^{50}$ menjelaskan tokoh agama dan tokoh masyarakat masih kuat berpandangan bahwa pemakaian alat kontrasepsi lebih pantas dilakukan oleh perempuan dan masih tabu ketika laki-laki menggunakannya.

Selain dari beberapa kajian di atas, sebenarnya diskursus tentang tokoh agama sudah cukup banyak dikaji dan tidak disangkal bahwa tema-tema terkait tokoh agama marak dikaji oleh kalangan akademisi dan praktisi. Meskipun demikian, berangkat dari kajian sebagaimana tercantum di atas, kajian terkait kontestasi untuk memperebutkan legitimasi masyarakat pedesaan, sejauh hasil kajian pustaka yang telah dilakukan, penulis belum menemukan secara spesifikasi perbincangan kontestasi tokoh agama yang berada di pedesaan. Oleh sebab itu, penelitian ini penulis mendiskusikan tokoh agama dari sisi yang berbeda, di mana penulis mengkaji kontestasi tokoh agama dalam memberikan bimbingan Islam kepada masyarakat Islam di pedesaan.

${ }^{47}$ Al Makin, "Not a Religious State: A Study of Three Indonesian Religious Leaders on Relation of State and Religion", Journal Indonesia and the Malay World, Volume 46, 2018 (Published Online: 11 Oct 2017 ), 95 116.

48 Health Policy Initiatif, 2013, "Engaging Religious Leaders in the Response to HIV and AIDS in Tanzania", dalam https://www.kebijakanaidsindonesia.net/id/component/j downloads/send/4-policybrief/151-engaging-religious-leaders-in-the-response-to-hiv-and-aids-in-tanzania diakses 24 Desember 2019.

${ }^{49}$ Mark H. Anshel dan Mitchell Smith, "The Role of Religious in Promoting Healty Habits in Religious Institutions", Journal of Religioun and Health, Springer Science and Bussines Media New York, Vol. 52, No. 1 (Marc 2013).

${ }^{50}$ Hartini, "Pandangan Tokoh Agama dan Budaya Masyarakat terhadap Pemakaian Alat Kontrasepsi", EGALITA: Jurnal Kesetaraan dan Keadilan Gender, Vol. 6, No. 1, (2011) dalam http://ejournal.uinmalang.ac.id/index.php/egalita/article/view/2120 diakses 24 Desember 2019. 


\section{Landasan Teoretis}

Dalam landasan teoretis ini, penulis mendiskusikan beberapa teori yang dianggap relevan guna membantu tokoh agama, bimbingan Islam, masyarakat pedesaan, dan kontestasi.memudahkan penulis untuk melaksanakan penelitian ini. Landasan teoretis yang dibangun meliputi,

Dalam kehidupan masyarakat, tokoh agama merupakan sebutan dari para pengajar ilmu agama, seperti ustaz, kiai, guru, dan sebagainya. ${ }^{51}$ Mereka dianggap masyarakat sebagai orang berilmu pengetahuan agama yang luas dan berakhlak mulia, sehingga masyarakat menghormatinya. ${ }^{52}$ Ada empat komponen yang melekat pada diri tokoh agama yaitu: pengetahuan agama, kekuatan spiritual, keturunan (baik spiritual maupun biologis), dan moralitas. Ketokohan mereka memang tidak diangkat secara formal sebagai pemimpin. ${ }^{53}$ Akan tetapi disebabkan mereka memiliki sejumlah kualitas unggul, sehingga mereka mencapai kedudukan sebagai orang yang memiliki kemampuan untuk memengaruhi kondisi perilaku dan psikis individu atau kelompok masyarakat.

Tidak dimungkiri bahwa tokoh agama masih memiliki pengaruh yang sangat besar. Keikutsertaan masyarakat dalam pembangunan, tergantung kepada partisipasi tokoh agama di tempatnya masing-masing. Karena tanpa keikutsertaan tokoh agama dalam kegiatan pembangunan, maka kegiatan tersebut kurang kondusif dan maksimal. Adapun gelar yang diberikan kepada tokoh agama memiliki dua kriteria, yaitu: memiliki ilmu pengetahuan agama Islam dan mendapatkan legitimasi masyarakat. ${ }^{54}$ Dalam penelitian ini, masyarakat yang penulis maksud adalah masyarakat desa.

Masyarakat desa merupakan orang-orang yang bertempat tinggal di mana terdapat jumlah penduduk 2.500 orang, yang ditandai dengan derajat intensnya pergaulan dengan sesamanya. ${ }^{55}$ Selain itu, desa dianggap sebagai kesatuan hukum yang memiliki susunan asli yang didasarkan hak asal-usul bersifat istmewa. Corak berpikirnya dalam pemerintahan desa memiliki keanekaragaman, otonomi asli, partisipasi, pemberdayaan masyarakat, dan demokratisasi.56 Ketika melihat desa dari letak geografisnya, maka desa adalah hasil perwujudan budaya, politik, sosial, dan geografis yang terdapat di suatu daerah, serta mempunyai hubungan timbal balik dengan daerah yang lain. ${ }^{57}$ Letak geografisnya merupakan faktor yang memberi pengaruh terhadap kegiatan gotong royong, seperti faktor topografi setempat, faktor iklim yang dapat memengaruhi, baik positif maupun negatif terhadap masyarakat, terlebih bagi para petani. Karena tidak dapat dimungkiri, bencana alam juga dapat menjadi faktor yang harus dilewati secara bersama. ${ }^{58}$ Oleh sebab itu, pengalaman dan pergaulan nasib dapat menimbulkan keakraban dalam hubungan bermasyarakat.

51 Kiai merupakan tokoh yang sangat penting dalam suatu pondok pesantren. Karena maju mundurnya pondok pesantren tergantung dari kewibawaan dari kiai. Oleh sebab itu, tidak dapat disangkal bahwa ketika kiai di salah satu pondok pesantren meninggal dunia, maka popularitas pondok pun akan merosot disebabkan kiai yang menjadi pengganti tidak sepopuler kiai yang telah meninggal dunia tersebut. Lihat Saiful Akhyar Lubis, Konseling Islami: Kiai dan Pesantren (Yogyakarta: eLSAQ Press, 2007), 169

52 Ronald, Tokoh Agama dalam Masyarakat (Jakarta: Rineka Cipta, 2004), 23.

53 Kartini Kartono, Pemimpin dan Kepemimpinan, Apakah Pemimpinan Abnormal Itu? (Jakarta: Raja Grafindo Persada, 1998), 10.

54 Taufik Abdullah, Agama dan Perubahan Sosial ( Jakarta: CV Rajawali, 1983), 18.

55 Syamsul Nizar, Sejarah Sosial dan Dinamika Intelektual (Jakarta: Kencana Prenada Media Group, 2013), 249.

${ }^{56}$ H.A.W. Widjaja, Pemerintahan Desa/Marga (Jakarta: PT. Raja Grafindo Persada 2003), 3.

57 R. Bintaro, Dalam Interaksi Desa-Kota dan Permasalahannya (Jakarta: Ghalia Indonesia, 1989).

58 Ziauddin Sardar, Tantangan Dunia Islam Abad 21: Menjangkau Informasi (Bandung: Mizan, 1998), 141. 
Hubungan yang terbangun dalam kehidupan masyarakat desa terjadi secara kekeluargaan dan jauh terkait pelbagai masalah pribadi. Mereka hidup saling menghayati. Ketika seseorang di antara mereka merasakan suka dan duka, maka seluruh masyarakat pun merasakannya. Pertemuan dan kerja sama dalam sosial lebih diprioritaskan dari pada kepentingan pribadi. Kehidupan masyarakat sehari-hari diwarnai dengan gotong royong, seperti mendirikan tempat ibadah, rumah, bersawah, dan melayat ke rumah orang yang meninggal dunia. ${ }^{59}$ Selain itu, kehidupan keagamaan dalam masyarakat berlangsung sangat serius. Semua kehidupan dan tingkah laku mereka dijiwai oleh agama. Hal tersebut disebabkan cara berpikir masyarakat desa kurang rasional.60

Berbicara terkait masyarakat desa, maka hal ini ini tidak dapat dipisahkan dari peran tokoh agama dalam memberikan bimbingan Islam. Tokoh agama adalah aktor yang mampu memainkan peran penting dalam kehidupan masyarakat. Kehadiran mereka di tengah masyarakat memiliki pengaruh besar dan dipandang sangat penting. Terlebih kontribusi mereka dalam memberikan bimbingan Islam. Tohari Musnamar mendefinisikan bimbingan Islam sebagai proses pemberian bantuan terhadap individu atau kelompok, agar mampu hidup selaras dengan ketentuan Allah SWT. Sehingga demikian itu dapat mencapai kebahagiaan, baik dunia maupun akhirat.61 Selain itu, Anwar Sutoyo mendefinisikan bimbingan Islam sebagai suatu usaha guna membantu individu atau kelompok dalam menyelesaikan pelbagai permasalahan dalam pengembangan fitrah keberagamaan yang dimiliki. Sehingga mereka dapat menyadari peran pentingnya sebagai khalifah di bumi dan memiliki fungsi untuk mengabdi dan menyembah Allah SWT. Sehingga demikian itu, pada akhirnya terjalin hubungan yang baik dengan Allah SWT, alam, dan sesama manusia. ${ }^{62}$

Adapun dalam memberikan bimbingan Islam kepada masyarakat di pedesaan, seorang tokoh agama dituntut untuk memiliki wawasan keilmuan yang luas dan dibarengi dengan pengalaman yang matang. Sehingga hal tersebut memungkinkan mereka mendapatkan legitimasi dari masyarakat dan dipercayai untuk membimbing mereka. Oleh sebab itu, tidak dimungkiri bahwa untuk mendapatkan legitimasi masyarakat berindikasi terjadinya kontestasi di kalangan tokoh agama. Kontestasi merupakan sistem yang memperebutkan dukungan rakyat. ${ }^{63}$

Antje Wiener menyebutkan bahwa teori kontestasi terdiri dari empat fitur utama, yaitu: Pertama, mencakup tiga jenis norma (norma dasar, prinsip pengorganisasian, dan prosedur standar). Kedua, empat mode kontestasi (arbitrase, musyawarah, pertengkaran dan pembenaran). Ketiga, tahap implementasi norma. Keempat, tiga segmen pada siklus validasi norma (validasi formal, pengakuan sosial, validasi budaya). Berdasarkan keempat fitur tersebut, maka dapat mengidentifikasi legitimasi kesenjangan dalam sektor kebijakan apa pun yang dipilih dari tata kelola global. ${ }^{64}$ Oleh sebab itu, Antje Wiener menyebutkan bahwa terjadinya kontestasi adalah untuk mendapatkan legitimasi atau pengakuan dari orang lain terhadap dirinya. ${ }^{65}$

${ }^{59}$ Moh. Fadli, dkk., Pembentukan Peraturan Desa Partisipatif: Head to A Good Village Governance (Malang: UB Press, 2011), 98.

60 Pior Stompka, Sosiologi Perubahan Sosial (Jakarta: Penanda Media Group, 2008), 67.

61 Tohari Musnamar, Dasar-Dasar Konseptual Bimbingan dan Konseling Islami (Yogyakarta: UII Press, 1992), 5.

${ }^{62}$ Anwar Sutoyo, Bimbingan dan Konseling Islami: Teori dan Praktik (Yogyakarta: Pustaka Pelajar, 2013), 25.

${ }^{63}$ Pusat Bahasa Departemen Pendidikan Nasional RI, Kamus Bahasa Indonesia (KBBI) (Jakarta: Balai Pustaka, 2008), 805.

${ }^{64}$ Antje Wiener, A Theory of Contestation ..., 7

65 Ibid., 8. 
Walter Bryce Gallie membagi dua gagasan konsep yang diperebutkan dan persepsinya dalam lintas ilmu sosial, yaitu: Pertama, prinsip sebesar apa kekuatan yang diperoleh atas penerimaan orang lain terhadap mereka. Kedua, persepsi untuk mempertahankan dan mengubah prinsip-prinsip dasar yang tertunda oleh konteks. ${ }^{66}$ Oleh sebab itu, diperlukan makna mendalam untuk mempertimbangkan konsep universal, yaitu dengan menilai peran dan dampak prinsip-prinsip tersebut. Dalam pengertian kritis tersebut, setidaknya kontestasi telah menghasilkan serangkaian konsep yang diperebutkan, terlebih khusus dalam praktiknya.

Tokoh agama memiliki otoritasnya masing-masing dalam kehidupan masyarakat. Otoritas tokoh agama terbentuk atas akumulasi habitus mereka, baik dari genealogi, pendidikan, dan legitimasi institusi. Selain itu, otoritas tokoh agama pun turut dibentuk dengan kondisi sosial. Pertama, budaya yang menempatkan tokoh agama sebagai orang yang musti dihormati setelah orang tua. Kedua, adanya tradisi acabis untuk beragam kepentingan. Ketiga, lahir batin dengan masyarakat. Keempat, dimensi mistis yang dilekatkan pada tokoh agama. Kelima, loyalitas para jemaah dan masyarakat. ${ }^{67}$ Tokoh agama dianggap dan diyakini memiliki kekuatan spiritual, sehingga keberadaan mereka mendapat dukungan banyak orang. Meskipun demikian, ada juga keberadaan tokoh agama yang kurang dianggap banyak orang. Sehingga hal itu menjadikan dirinya untuk mencari dan membangun otoritasnya sendiri.

Menurut Max Weber, setidaknya ada tiga perspektif terkait fenomena kepemimpinan. ${ }^{68}$ Pertama, kepemimpinan dapat dianggap sebagai kemampuan dalam diri seseorang. Demikian itu menandakan bahwa seseorang tersebut memiliki daya tarik sendiri, sehingga dapat menyebabkan orang lain menerima kehendaknya sebagai sesuatu yang harus diteladani. Hal itu dikarenakan dirinya memiliki sifat yang supernatural dan dapat memperoleh massa yang banyak dari masyarakat. Kepemimpinan yang mendapatkan kekuatan dari orang banyak disebut otoritas karismatik (charismatic authority). Kedua, kepemimpinan tidak berkonsentrasi pada kekuatan individu, sehingga otoritasnya dibentuk dari posisi atau status yang dipegangnya. Kepemimpinan seperti ini dikenal dengan otoritas legal (legal authority). Kekuatan dan haknya dalam memimpin harus mematuhi prosedur organisasi yang dipegangnya. Ketiga, keyakinan terhadap waktu dan kebiasaan yang dapat dimiliki oleh individu atau kelompok. Individu atau kelompok yang memiliki otoritas ini dihormati karena mereka mempunyai kekuasaan dan otoritas yang telah melembaga dan bahkan menjiwai masyarakat. Kepemimpinan tersebut dikenal dengan istilah otoritas tradisional (traditional authority).

\section{B. Mengenal Kisah Hidup Guru Tua Dan Ustaz Muda \\ 1. Biografi Guru Tua}

Guru Tua lahir pada tanggal 04 April 1968, di Desa Kayu Besi, Bangka Belitung. Ia merupakan anak pertama dari pasangan suami-istri yang bersahaja Zamhari dan Zuna. Orang tua Guru Tua, Zamhari dan Zuna adalah guru ngaji di Desa Kayu Besi. Terlahir dari genealogi guru ngaji, Guru Tua sangat terpengaruh oleh figur sang ayah. "Semasa saya kecil, ayah sudah sangat tegas memerintahkan untuk mempelajari ilmu agama, terlebih belajar

\footnotetext{
${ }^{66}$ Walter Bryce Gallie, Arts as an Essentianlly Contested Concepts': The Philosophical Quarterly (New York: Schocken Books, 1956), 168.

67 Pierre Bourdieu, Arena Produksi Kultural: Sebuah Kajian Sosiologi Budaya, terj. Yudi Santosa (Jakarta: Kreasi Wacana, 2015).

${ }^{68} \mathrm{M}$. Weber, The Theory of Social and Economic Organization, Transleted by Talcott Parson (New York: The Fress Press, 1966), 358.
} 
membaca Al-Qur'an. Saya pun belajar membaca Al-Qur'an dari ayah saya. Beliau juga sudah mengajari saya agar hidup mandiri. Saya pun sering membantunya bekerja di kebun," kata Guru Tua sebagaimana penulis kutip dari hasil wawancara dengannya. Bagi Guru Tua, sang ayah merupakan first real teacher (guru sejati pertama). Sebab berkat sang ayah, Guru Tua dapat memetik hikmah dari ketegasannya untuk mempelajari ilmu agama sedari kecil.

Sejak usia 7 - 9 tahun, Guru Tua sudah mulai menampakkan kecerdasannya dalam ilmu agama. Kepribadiannya yang baik mulai memperlihatkan bahwa dirinya mampu menjaga ajaran agama agar tetap eksistensi di desanya. Terlebih sedari kecil, Guru Tua memiliki kegemaran dalam membaca kitab-kitab, sehingga kecerdasannya sudah tertempa. Selain itu, suasana di lingkungan keluarga yang menaruh perhatian besar terhadap ilmu pengetahuan turut membangun perkembangan intelektual Guru Tua. Sang ayah kerap kali mengajak Guru Tua untuk menghadiri majelis ilmu dan acara-acara keagamaan di desanya, seperti tahlilan dan maulidan.

Kepribadian yang baik dan kecerdasan Guru Tua tetap berada pada dirinya hingga ia tumbuh dewasa. Sifat baik tersebut ternyata membuat seorang wanita yang bernama Zaliha memendam rasa. Cinta Zaliha pun dibalas oleh Guru Tua sehingga keduanya bersepakat untuk menuju ke pelaminan. Alhasil, pada tahun 1990 pernikahan pun terlaksana dengan penuh kebahagiaan. Dari pernikahan tersebut, mereka dikaruniai 4 orang anak yaitu: Maratul 'Arifah, Abdullah Albajali, Wafiq Faizah, dan Muhammad Taqiyuddin.

Guru Tua sangat beruntung memiliki sosok istri seperti Zaliha, karena sang istri sangat bersabar dan mendukung kegiatan Guru Tua memberikan bimbingan Islam kepada masyarakat. Dukungan tersebut diberikan sang istri sebab Zaliha sangat mengerti bahwa tugas Guru Tua sebagai kepala keluarga dan seorang pembimbing itu sangat berat. Oleh sebab itu, Zaliha meminta izin kepada Guru Tua untuk membantu perekonomian keluarga dengan membuka warung bakso di rumahnya. Dengan sikap santun Guru Tua mengizinkannya asal tidak terlalu memaksakan, sebab kesehatan harus selalu diperhatikan. Meskipun demikian, Guru Tua yang tidak mau memberatkan sang istri, maka ia pun turut membantu mempersiapkan segala perlengkapannya. Setiap pagi Guru Tua berangkat ke pasar untuk membeli daging sapi dan bahan-bahan lain yang diperlukan. Setelah itu, Guru Tua pun menggiling daging sendiri di rumahnya, demi menjaga kebersihan dan kehalalannya.

Ayah Guru Tua sangat menaruh perhatian besar terhadap dunia pendidikan. Terlebih anggapan sang ayah bahwa pendidikan itu sebagai bridge of life (jembatan kehidupan), sehingga sejatinya manusia dipandang dan dihormati disebabkan memiliki ilmu pengetahuan. Beranjak usia Guru Tua 7 tahun, tepatnya tahun 1975, dirinya dititipkan sang ayah ke SD N 46 Kayu Besi, seraya mengatakan, "Ini anak, saya titipkan kepada bapak dan ibu guru. Tolong dididik dengan benar. Jika anak saya nakal, tolong berikan hukuman. Tidak apa-apa, karena itu semua demi kebaikannya," begitulah ungkapan yang penulis kutip dari hasil wawancara dengan ibunda Guru Tua yang menceritakan ketegasan sang ayah. Guru Tua sangat bersemangat dalam menjalankan hari-harinya belajar di sekolah. Ia pun dikenal pandai dan sopan. Sepulang Guru Tua dari sekolah, tidak langsung pergi bermain dengan teman-temannya, akan tetapi ia masih menyusul sang ayah di ladang dan membantunya. Guru Tua kecil memang dikenal rajin dan jarang sekali bermain, namun bukan berarti tidak pernah bergaul dengan teman-teman. Jika ada waktu luang dan diizinkan oleh ayahnya, maka ia pun bermain bersama teman-temannya.

Semasa kecil, Guru Tua menggemari permainan sepak bola. Ia pun bersama teman-teman bermain sepak bola jika ada waktu luang. Akan tetapi, demikian itu tidaklah berjalan lama, sebab seiring berjalannya waktu kegemaran itu pun pudar. Guru Tua lebih memilih 
membantu sang ayah berkebun sembari mendalami ilmu agama kepada para alim ulama yang masyhur di masanya.

Pada tahun 1981, Guru Tua berhasil menyelesaikan sekolahnya dengan nilai yang sangat baik. Selama 6 tahun bergelut dalam dunia pendidikan tidaklah membuat Guru Tua merasa cukup. Oleh sebab itu, dengan tekad yang kuat ia pun melanjutkan pendidikannya ke Madrasah Diniyah tingkat Wustho Nurul Huda yang setara dengan SMP/MTs. ${ }^{69}$ Setelah Guru Tua menyelesaikan di sekolah tersebut, ia pun tidak bisa lagi melanjutkan ke jenjang berikutnya. Permasalahan tersebut dikarenakan perekonomian keluarga yang tidak memungkinkan dan menyanggupi untuk meneruskan pendidikan formalnya. Menghadapi permasalahan tersebut tidak mengecilkan semangat Guru Tua dalam mencari ilmu pengetahuan, sehingga ia pun meminta izin kepada ayah dan ibundanya untuk belajar ilmu agama kepada para alim ulama yang terkenal di masanya. Mendengar niat baik Guru Tua, sang ayah dan ibunda pun tak sadar meneteskan air mata dan dengan senang hati mengizinkannya.

Setelah mendapatkan izin dari sang ayah dan ibunda tercinta, Guru Tua mulai melakukan perjalanan intelektualnya dengan belajar agama kepada Guru H. Muaz Nur, tepatnya dari tahun 1982 - 1988. Guru yang akrab disapa masyarakat dan kalangan santri dengan panggilan Guru Muaz, terkenal sangat alim, berwibawa dan bersahaja. Beliau berasal dari Desa Payabenua, Kecamatan Mendo Barat, Kabupaten Bangka. Guru Muaz merupakan lulusan dari Pondok Pesantren Nurul Islam (PPNI) di Desa Sribandung, Kecamatan Tanjung Batu, Kabupaten Ogan Ilir, Palembang. Guru Tua mempelajari banyak hal dari sang guru, khususnya dalam bidang ilmu agama. Dari sang guru, Guru Tua mendalami ilmu ketuhanan, akhlak, dan fikih. Kepada sang guru, Guru Tua mengkaji beberapa kitab. Bidang ilmu tauhid, menggunakan kitab Nurul Jalal fi Ma'rifatillah Dzil Jalal yang dikarang oleh Tuan Guru Zahruddin Asahan. Selanjutnya dalam bidang akhlak, menggunakan kitab Ta'alim alMuta'allim Thariq al-Ta'allum karangan Syaikh Burhanuddin al-Zarnuji. Kemudian dalam bidang fikih, menggunakan kitab Safinatun Naja fi 'Ilmi al-Fiqh karangan Syaikh Salim bin Sumair al-Hadhrami al-Yamani.

Setelah menyelesaikan beberapa kajian kitab bersama Guru Muaz, Guru Tua lantas melanjutkan perjalanan intelektualnya kepada Guru Muhammad Thoyyib al-Banjari, tepatnya dari tahun 1990 - 2006. Guru Thoyyib, begitulah masyarakat memanggilnya. Sang guru yang berasal dari kota Banjar, Kalimantan Selatan itu merupakan saudara sepupu dari Syaikh Abdurrahman Siddik al-Banjari. Sang guru tidak hanya dikenal alim, namun juga sifat ketawadukan dan kewarakan pada dirinya menjadi nilai lebih, sehingga membuat dirinya disegani dan dihormati. Dari sang guru, Guru Tua mendalami ilmu nahu, tasawuf, saraf, dan fikih. Bidang nahunya, menggunakan beberapa kitab yaitu Matan al-Jurumiyyah karangan Abu Abdillah Sidi Muhammad bin Daud an-Shanhaji, Mutammimah al-Jurumiyyah fi 'Ilmi al'Arobiyyah karangan Syaikh Syamsuddin Muhammad bin Muhammad ar-Ro'ini, dan alKawakib ad-Durriyah Syarh Mutammimah al-Jurumiyyah karangan Syaikh Muhammad bin Ahmad al-Ahdal. Selanjutnya dalam bidang tasawuf, menggunakan kitab Siyarus al-Salikin ila Ibadat Robbil 'Alamin karangan Syaikh Abdul Shomad al-Falimbani. Kemudian bidang ilmu saraf (perubahan kata-kata), menggunakan beberapa kitab yaitu, Amtsilati karangan

${ }^{69}$ Sekolah tersebut berada di Desa Nibung, Kecamatan Puding Besar, Kabupaten Bangka, namun sekarang sekolah tersebut sudah tidak berjalan lagi. Informasi ini didapatkan dari istri Guru Tua yang juga merupakan alumni dari sekolah tersebut,"Sudeh akak SD, nya sekulah di kampong kameny di Nibong. Nama e duluk ya Madraseh Diniyeh tingkat Wustho, men sekarang ne setingkatlah kek SMP/MTs, nama sekulah kameny duluk Nurul Huda," Zaliha, Wawancara, Kediamannya di Desa Kayu Besi, Kecamatan Puding Besar, Kabupaten Bangka, 26 Desember 2019. 
KH. Taufiqul Hakim dari Jepara, Jawa Tengah, dan Syarh al-Kailany li Tashrifi al-Izziy karangan Syaikh Abu Hasan Ali bin Hisyam al-Kailany. Bidang fikihnya, menggunakan kitab Sabilal Muhtadin lit Tafaqquh fi Amri ad-Din karangan Syaikh Muhammad Arsyad alBanjari.70

Selain mendalami ilmu agama dengan Guru Thoyyib al-Banjari, Guru Tua juga belajar dengan Guru Munzal yang berasal dari Desa Paya Benua, Kecamatan Mendo Barat, Kabupaten Bangka, selama 16 tahun yaitu dari 1990 - 2006. Guru Munzal adalah sosok guru yang dihormati dan disegani oleh Guru Tua. Kealiman sang guru didapatkan dari majelismajelis ilmu yang ia pelajari dari para pemuka agama yang masyhur pada masanya. Salah satunya adalah Guru Thoyyib al-Banjari. Guru Munzal dipercayai oleh Guru Thoyyib alBanjari untuk mengajarkan agama. Kepada Guru Munzal, Guru Tua mendalami ilmu tauhid dan tasawuf. Bidang tauhid, menggunakan kitab Kasyful Ghoibiyyah yang dikarang oleh Syaikh Zainal 'Abidin bin Muhammad al-Fathoni. Bidang tasawufnya menggunakan kitab Siyarus al-Salikin ila Ibadat Robbil 'Alamin karangan Syaikh Abdul Shomad al-Falimbani.

Tidak hanya itu, Guru Tua juga mendalami ilmu agamanya dengan Guru Hasan Nusi yang berasal dari Desa Kemuja, Kecamatan Mendo Barat, Kabupaten Bangka, selama 4 tahun yaitu 1995 - 1999. Dari sang guru yang pernah menimba ilmu agama selama 13 tahun di kota Makkah al-Makarromah ini, Guru Tua mendalami bidang fikih, saraf, dan nahu. Bidang fikih, menggunakan kitab Sabilal Muhtadin lit Tafaqquh fi Amri ad-Din. Bidang ilmu saraf menggunakan kitab Amtsilati. Bidang nahunya menggunakan kitab Matan al-Jurumiyyah.

Terakhir, Guru Tua juga mendalami pengetahuan agamanya kepada Guru Muhsin Alwi yang berasal dari Desa Cit, Tiang Pulut, Bangka Belitung, selama 9 tahun yaitu 1988 - 2007. Guru Muhsin Alwi merupakan lulusan dari Pondok Pesantren Salaf Sidogiri, Kraton, Pasuruan, Jawa Timur. Kepada sang guru, Guru Tua mendalami ilmu dalam bidang akhlak dan fikih. Bidang akhlak, menggunakan kitab Akhlaqu lil Banin karangan Syaikh Umar bin Ahmad al-Baraja. Bidang fikihnya menggunakan beberapa kitab yaitu Fathul Mu'in karangan Syaikh Zainuddin bin Abdul 'Aziz al-Malibary, Tanbihul Ghofilin karya Abu al-Laits asSamarqandi, Hasyisyah al-Bajuri karangan Syaikh Ibrohim bin Muhammad bin Ahmad alBajuri, dan I'anah ath-Tholibin karangan Syaikh Ali bin Abdullah bin Muhammad Arsyad alBanjari.

Sejak 1988, bertepatan usia Guru Tua 20 tahun. Ia telah diminta masyarakat untuk mengajarkan anak-anak mereka membaca Al-Qur'an. Guru Tua pun bersedia untuk mengajari mereka. Pada tahun 1995, Guru Tua dimintai untuk mengajar di Madrasah Sanawiah dan Madrasah Aliyah dalam bidang agama Islam di Desa Puding Besar, Kabupaten Bangka. ${ }^{71}$ Tahun 1998 - sekarang, Guru Tua dipercayakan masyarakat untuk memberikan bimbingan Islam kepada mereka. Pada tahun 2002, Guru Tua diangkat menjadi bendahara masjid Baitul 'Izzah Desa Kayu Besi.

Guru Tua memberikan bimbingan kepada masyarakat pedesaan yang berada di rumahrumah warga. Desa di empat kabupaten Bangka Belitung (Bangka, Bangka Barat, Bangka Selatan, dan Bangka Tengah) sudah pernah ia singgahi untuk membimbing masyarakat. Namun, seiring banyaknya bermunculan para ustaz, maka hal itu membantu meringankan tugas Guru Tua untuk membimbing umat. Akhirnya, saat ini Guru Tua hanya memberikan bimbingan di Desa Kayu Besi, Kecamatan Puding Besar, Kabupaten Bangka, dan Desa Kelapa,

\footnotetext{
${ }^{70}$ Guru Tua, Wawancara, di Kediamannya, Desa Kayu Besi, Kecamatan Puding Besar, Kabupaten Bangka, 23 Desember 2019.

${ }^{71}$ Madrasah tersebut berdiri pada tahun 1988 yang diprakarsai oleh Sapadin (almarhum). Namun cukup disayangkan madrasah tersebut sudah tidak berjalan lagi, sehingga sekarang diaktifkan dengan adanya TK PAUD (taman kanak pendidikan usia dini).
} 
Kabupaten Bangka Barat. Selain itu, Guru Tua juga acap kali diundang masyarakat untuk mengisi acara PHBI (perayaan hari besar Islam), menjadi khotib, dan memimpin acara-acara keagamaan lainnya (tahlilan, maulidan, dan yasinan).

Adapun jadwal Guru Tua dalam memberikan bimbingan yaitu: pada hari senin - kamis, selesai salat Magrib, ia mengajarkan cara membaca Al-Qur'an untuk anak-anak. Hari Minggu, tepatnya selesai salat Isya, Guru Tua memberikan bimbingan di kediaman Bapak Mansur di Desa Kayu Besi, Kabupaten Bangka. Di kediaman tersebut, ia menyuguhkan materi tauhid dengan menggunakan kitab Aqoidul Iman karangan Syaikh Abdurrahman Siddik al-Banjari dan Tuhfah al-Raghibin fi Bayani Haqiqah Iman al-Mu'minin wa ma Yufsiduhu Riddah alMurtaddin karya Syaikh Muhammad Arsyad al-Banjari.

Setiap hari Selasa, selesai salat Isya, Guru Tua memberikan bimbingan kepada anak-anak muda di Desa Kayu Besi. Dalam kegiatan bimbingan tersebut, ia menggunakan kitab Asroris Sholah karangan Syaikh Abdurrahman Siddik al-Banjari. Malam Rabu, selesai Isya, ia membimbing masyarakat di Musala Desa Kayu Besi dengan materi tasawuf yang mana menggunakan kitab al-Yawaqit wal Jawahir fi 'Uqubat Ahlil Kabair karangan Syaikh Muhammad 'Ali bin 'Abdul Rashid al-Jawi. Kemudian pada hari Sabtu, selesai Isya, Guru Tua memberikan bimbingan pada masyarakat di Desa Kelapa, Kabupaten Bangka Barat, dengan materi tauhid. Kitab yang digunakan adalah Nurul Jalal fi Ma'rifatillah Dzil Jalal yang dikarang oleh Tuan Guru Zahruddin Asahan. ${ }^{72}$

Rumah Guru Tua setiap malam jarang terlihat sepi. Semua itu dikarenakan, tamu-tamu banyak berdatangan, baik dari masyarakat sekitar, sampai luar daerah. Sebagian mereka datang hanya sekadar bersilaturahmi dan becengkrama, datang meminta solusi atas masalah dihadapi, dan diminta untuk me-ruqyah-kan mereka yang mendapatkan gangguan makhluk halus (jin).

\section{Biografi Ustaz Muda}

Ustaz Muda dilahirkan di Bangkalan Madura, Jawa Timur, pada 19 Agustus 1982. Orang tuanya bernama Irfan dan Hazirah. Semasa Ustaz Muda masih kecil, sang ayah sering mengajaknya untuk pergi ke sawah. Sang ayah pun menasihatinya dengan mengatakan "Anakku, hidup di dunia ini hanya sementara. Rizki, maut, jodoh itu sudah diatur sama Allah SWT, jadi jangan takut. Oleh sebab itu, kamu jangan lupa belajar, khususnya agama. Karena dengan ilmu agama, dirimu akan bahagia". ${ }^{73}$ Tidak dimungkiri bahwa nasihat dan kesabaran sang ayah, kerap kali menginspirasinya agar menjadi orang yang lebih baik lagi. Dalam beragama, sang ayah juga sangat tegas dan menaruh perhatian besar dalam pendidikan agama. Terlebih lagi, di lingkungannya sangat kental sekali nuansa keagamaannya.

Mafhumnya anak kecil, Ustaz Muda senang sekali bisa bermain bersama temantemannya. Meskipun demikian, kesenangan tersebut tidak berlarut sampai tumbuh dewasa. Sehingga hal itu, tidak membuat ia lalai dalam permasalahan belajar. Semasa Ustaz Muda kecil, ia dikenal sangat mudah bergaul dan ia sosok yang cerdik. Postur tubuhnya yang mungil membuat ia dipanggil dengan sebutan Rozi kecil.74

Pada tahun 2007, Ustaz Muda menikah dengan seorang wanita idaman yang juga sedaerah dengannya yaitu Muhimmah. Muhimmah adalah sosok istri yang sangat sederhana. Ia sangat mendukung kegiatan sang suami, walaupun harus menghadapi masa yang penuh

\footnotetext{
72 Observasi ke Kediaman Guru Tua di Desa Kayu Besi, Kecamatan Puding Besar, Kabupaten Bangka, 23 Desember 2019 - 20 Januari 2020.

73 Ustaz Muda, Wawancara, Kediamannya di Desa Kayu Besi, Kecamatan Puding Besar, Kabupaten Bangka, 27 Desember 2019.

${ }^{74}$ Muhimmah, Wawancara, Kediamannya di Desa Kayu Besi, Kecamatan Puding Besar, Kabupaten Bangka, 28 Desember 2019.
} 
suka dan duka. Dari pernikahan tersebut, mereka dianugrahi 4 orang anak. Anak pertamanya diberi nama, Muhammad Basyir. Kemudian yang kedua adalah Fadilah. Selanjutnya, Ahmad Mubarrok. Terakhir diberi nama Hamid Irfan.

Pada tahun 1988, bertepatan umur Ustaz Muda 6 tahun. Ia sudah masuk ke sekolah dasar untuk umumnya. Sekolah agamanya di madrasah ibtidaiyah (MI) di Bangkalan Madura. Ustaz Muda sangat rajin dalam masalah pembelajaran, sehingga pada tahun 1994, ia menyelesaikan pendidikannya dengan nilai yang cukup memuaskan. Ustaz Muda sangat berantusias untuk bersekolah. Hal itu terbukti, ketika di desanya tidak ada Sekolah Menengah Pertama (SMP), maka ia melanjutkan ke kelas 7 yang mereka buat sendiri di desanya. 75

Melihat semangat Ustaz Muda dalam belajar tinggi, terlebih dalam bidang agama, maka orang tuanya mengirimkannya ke Pondok Pesantren Syaikhona Cholil Bangkalan. Jarak pondok pesantren tersebut dari desanya ditempuh perjalanan selama 4 jam. Namun di pondok tersebut Ustaz Muda tidak sekolah umum. Mengingat perekonomian keluarga yang tidak sanggup menyekolahkannya ke jenjang formalnya, maka Ustaz Muda dititip sang ayah kepada pengasuh Pondok Pesantren Syaikhona Cholil Bangkalan yang sekarang diasuh oleh Raden Kiai Haji (RKH) Fachrillah Aschal. Orang tuanya berharap, di pondok pesantren tersebut Ustaz Muda bisa digembleng dalam bidang ilmu agamanya.

Di pondok pesantren tersebut, Ustaz Muda memulai lagi dari kelas 4 ibtidaiyah. Ia sangat bersyukur masih bisa disekolahkan dan belajar di sana. Ustaz Muda sangat rajin dalam mengikuti pelajaran agama, sehingga tidak mengenal lelah. Sikapnya yang tidak mengenal lelah tersebut membuat kondisi tubuhnya lemah. Sehingga ia mengalami sakit parah dan lumpuh sementara. Hal itu diketahui oleh pengasuh. Ketika ia sudah sembuh, pengasuhnya pun menegurnya agar tidak terlalu memaksakan tubuh, karena tubuh pun perlu diistirahatkan. Ustaz Muda menyelesaikan studinya di pondok pesantren tersebut sampai kelas Aliah.

Selama di pondok pesantren, Ustaz Muda mendalami ilmu agama, dari beberapa alim ulama yaitu: KH. Muhammad Khalili, Abdullah Sachal, beberapa alumni dari Pesantren Sidogiri, Kraton Pasuruan Jawa Timur, dan Pondok Pesantren Mambaul Ulum Bata-Bata, serta Pondok Pesantren al-Hamidi Banyu Anyar. Ustaz Muda mempelajari ilmu agama, seperti fikih, tauhid, nahu, alat, faroid, tafsir dan hadis. Dalam bidang fikihya, menggunakan beberapa kitab, yaitu: Safinatun Naja, Fathul Qorib, Tuhfatut Tullab, I'anah at-Tholibin, Syarqowi, Tukhfatul Mukhtar, Nihayatul Mukhtaj, al-Fiqhul Islam wa Adillatuhu karya Wahbah az-Zuhaili.

Bidang tauhidnya, menghatamkan beberapa kitab, yaitu: Tijan Dhorori, Jawahirul Kalam, al-Ajwibah al-Ghaliyah fi 'Aqidah al-Firqah an-Naajiyah karangan Habib Zein bin Ibrohim bin Smith, Jauharut Tauhid, Aqidatul Awam, Kifayatul Awam. Selanjutnya bidang nahu, menggunakan beberapa kitab, yaitu: Matan Jurumiyah, Mukhtasor Jiddan, Syarah alJurumiyah, Taswiqul kholan, Kafrowi, Asmawi, Imriti, Alfiyah, Kifayatul Habib, dan Mughnil Labib.

Kemudian dalam bidang ilmu Sarafnya menggunakan beberapa kitab yaitu: Amsilati, alKaylani lil al-Tashrif al-'Izzi, dan Nazhom Maqsud. Adapun ilmu Balaghoh-nya meliputi Ma'ani, Badi', dan Bayan. Bidang usul fiqih-nya, menggunakan kitab, yaitu: Latoiful Isyaroh dan al-Kholaf. Bidang ilmu tafsirnya, menggunakan beberapa kitab, yaitu: Tafsir Jalain, alMunir, al-Mughni, Sowi, al-Qawaid al-Asasiyah fi Ulumil Qur'an karya Sayid Muhammad al-

75 Ustaz Muda, Wawancara, Kediamannya di Desa Kayu Besi, Kecamatan Puding Besar, Kabupaten Bangka, 27 Desember 2019. 
Maliki al-Hasani, at-Tibyan fi Adab Hamalat al-Qur'an karya Imam Nawawi. Bidang hadisnya, yaitu: Hadis al-Arbain, Bulughul Marom, Riyadhus Solihin, Sohih Muslim dan Bukhori. Kemudian untuk bidang tasawufnya yaitu: Bidaya al-Hidayah, Ihya' 'Ulumuddin, Mauidotul Mukminin, Ayyuhal Walad, Minhus Saniyah, dan Tukhfatus Saniyah.76

Kedatangan Ustaz Muda ke Bangka Belitung berawal dari kegiatan pengiriman guru tugas oleh Pondok Pesantren Syaikhona Cholil Bangkalan Madura. Berhubung guru tugas yang diminta disyaratkan yang sudah menikah, maka ditunjuklah Ustaz Muda untuk menjalankan tugas tersebut. Karena ia baru saja melaksanakan pernikahan. Maka dari itu, pada tahun 2007 Ustaz Muda beserta istri berangkat ke Bangka Belitung.

Menariknya, Ustaz Muda beserta istri kebingungan, sebab tidak mengetahui tempat tujuannya. Mereka berangkat dari Jawa Timur ke Jakarta menggunakan bis, kemudian dari Jakarta ke Bangka Belitung naik kapal laut. Setibanya di Bangka, kebingungan tersebut semakin bertambah, karena baru pertama kalinya merantau dan tidak memiliki alat komunikasi.

Setelah sesaat kemudian, datang seseorang yang ditugaskan untuk menjemputnya di pelabuhan dan dibawa ke Pondok Pesantren Ilzamun Maju Bahrin, Desa Kimak, Kabupaten Bangka. Tepat keberadaannya di pondok tersebut tiga bulan, maka Ustaz Muda pun tidak betah. Hal itu dikarenakan, laporan yang diinformasikan ke Pondok Pesantren Syaikhona Cholil Bangkalan ternyata tidak valid. Ternyata, informasi yang menyatakan bahwa Pondok Pesantren Ilzamun Maju Bahrin sudah memiliki tingkatan sanawi dan aliah, tidak benar adanya. Bukan hanya sanawiah dan aliah, di pondok tersebut bahkan belum memiliki ibtidaiyah dan santrinya hanya beberapa anak dari keluarga pengasuh.

Kejadian tersebut pun membuat Ustaz Muda kecewa, sehingga ia beserta istri meminta izin kepada pengasuh Pondok Pesantren Ilzamun Maju Bahrin untuk kembali ke Bangkalan, Madura. Ketika sudah mendapat izin pengasuh tersebut, Ustaz Muda tidak langsung pulang, akan tetapi ia pergi ke rumah Guru Munzal di Desa Paya Benua. Guru Munzal merupakan tokoh agama yang cukup berpengaruh di Bangka Belitung.

Setibanya di rumah Guru Munzal ternyata Ustaz Muda beserta istri tidak diizinkan untuk pulang ke Madura. Guru Munzal menawarkan sebidang tanah untuk dikelola dan membangun majelis taklim. Tidak berselang lama, ternyata datanglah 4 orang pemuda dari Desa Kayu Besi, Kabupaten Bangka, meminta Ustaz Muda untuk tinggal di Desa Kayu Besi. Mendengar permintaan keempat pemuda tersebut, maka Guru Munzal mengizinkan Ustaz Muda untuk menerima tawaran dari 4 pemuda tersebut. Alhasil, Ustaz Muda datang di Desa Kayu Besi dan diberikan rumah transmigran untuk tinggal. Satu bulan kemudian, Ustaz Muda dimintai untuk membimbing masyarakat Kampung Baru, Kabupaten Bangka Barat. Sepulangnya Ustaz Muda dari kegiatan bimbingannya, maka ia berniat untuk membuka kegiatan bimbingan di Desa Kayu Besi.

Kegiatan bimbingan yang ia laksanakan di Bangka Belitung cukup banyak, mulai jadi khotib sampai diminta untuk mengisi acara keagamaan di perayaan hari besar Islam (PHBI). Adapun rutinitas kegiatan bimbingan yang ia laksanakan, yaitu:

a. Setiap malam Minggu setelah salat Magrib, ia memberikan bimbingan Islam di Majelis Taklim Daarul Hijroh Desa Kayu Besi.

b. Setiap malam Minggu setelah salat Isya, ia memberikan bimbingan Islam di Masjid Baitul 'Izzah Desa Kayu Besi.

76 Ustaz Muda, Wawancara, Kediamannya di Desa Kayu Besi, Kecamatan Puding Besar, Kabupaten Bangka, 27 Desember 2019. 
c. Setiap malam Senin setelah salat Isya, ia memberikan bimbingan Islam di markas Majelis Pecinta Islam (MPI) di Desa Puding Besar, Kabupaten Bangka.

d. Setiap malam Kamis selesai salat Magrib, ia memberikan bimbingan Islam di Majelis Daarul Hijroh Desa Kayu Besi.

e. Setiap malam Kamis selesai salat Isya, ia memberikan bimbingan Islam di rumah Bapak Sudirman yang merupakan warga Desa Kayu Besi.

f. Setiap malam Rabu, ia memberikan bimbingan Islam di majelis taklim ibu-ibu, di Desa Puding Besar.

g. Setiap hari Jumat selesai salat Subuh, ia memberikan bimbingan Islam di masjid Baitul 'Izzah Desa Kayu Besi.

h. Setiap hari Jumat selesai salat Jumat, ia memberikan bimbingan Islam kepada majelis ibuibu di Pondok Pesantren Riyaadhul Jannah Desa Kayu Besi.

i. Ustaz Muda pun sebulan sekali sering dimintai untuk memberikan bimbingan Islam di markas Forum Jaga Bangka Belitung (FJB). ${ }^{77}$

Tidak hanya itu, eksistensi Ustaz Muda di Bangka Belitung juga cukup diperhitungkan. Hal itu ditandai dengan keaktifannya bergabung di beberapa instansi dan organisasi, yaitu: Pengasuh Pondok Pesantren Riyaadul Jannah Desa Kayu Besi, Pengurus Majelis Taklim Kutubus Salaf Bangka Belitung, Pengasuh Majelis Pecinta Islam (MPI) Bangka Belitung, Ketua umum Dewan Pimpinan Pusat Front Pembela Islam (DPP FPI) Bangka Belitung, dan Pengasuh Majelis Taklim Daarul Hijroh Desa Kayu Besi.

\section{Masyarakat Desa Kayu Besi di Bangka Belitung}

Sejak beberapa tahun silam sebelum Kayu Besi menjadi sebuah desa, wilayah tersebut masih berupa hutan rimba yang lebat. Wilayah tersebut dihidupi sebatang pohon yang tinggi menjulang dan berdiri kokoh, sehingga masyarakat bermaksud untuk menebang pohon itu. Ketika masyarakat hendak menedbang pohon tersebut, mereka pun dibuat heran olehnya, karena kayu yang ingin ditebang tersebut tidak tumbang (rebah), melainkan parang dan kapak yang digunakan menjadi patah. Berbagai upaya telah dilakukan untuk menebangnya. Kejadian itu pun mengundang tanda tanya bagi masyarakat, mereka mengatakan: "Alangkah ini kayu apa besi, kenapa sulit sekali ditebang?". Hal itu dilakukan sampai puluhan tahun lamanya. Seiring berjalannya waktu, pada akhirnya kayu itu pun tumbang dengan sendirinya sebab rapuh termakan usia. ${ }^{78}$

Di wilayah tersebut baru berdiri tujuh buah rumah warga. ${ }^{79}$ Mata pencaharian yang baru dilakukan masyarakat di sana adalah bercocok tanam (berkebun). ${ }^{80}$ Selanjutnya yang menjadi salah satu sifat masyarakat di sana adalah gotong royong yang mempunyai fungsi sosial. Dalam aktivitas tersebut terdapat unsur tolong menolong dan kebersamaan. Penyebar agama yang pertama kali di wilayah tersebut adalah Guru Hasan Nusi atau akrab disapa warga setempat dengan nama Guru Si. Beliau datang dari Desa Kemuja, namun

\footnotetext{
${ }_{77}$ Ustaz Muda, Wawancara, Kediamannya di Desa Kayu Besi, Kecamatan Puding Besar, Kabupaten Bangka, 27 Desember 2019.

${ }^{78}$ Kuris, Tokoh Masyarakat, Wawancara, kediamannya di Desa Kayu Besi, 19 Januari 2020.

79 Rumah-rumah tersebut adalah rumah Amang Akum (almarhum), Akek Cuh (almarhum), Mang Jawi (almarhum), Akek Jalil (almarhum), Akek Raman (almarhum), Akek Krusen (almarhum), dan Mang Mat Asis (almarhum). Informasi ini didapatkan dari Solnah, warga Desa Kayu Besi, Wawancara, 09 Januari 2020.

${ }^{80}$ Di sana masyarakat berkebun sahang (lada), singkong, karet, temulawak, jahe, cabai, dan lain sebagainya. Informasi ini didapatkan dari Solnah, warga Desa Kayu Besi, Wawancara ...
} 
meninggal di wilayah tersebut dan dikebumikan di sana pula. Makamnya diyakini keramat oleh masyarakat di wilayah itu. ${ }^{81}$

Desa Kayu Besi merupakan salah satu desa dari 7 desa di Kecamatan Puding Besar, dengan memiliki batas-batas wilayah, yaitu sebelah Utara berbatasan dengan Desa Mabat, Kecamatan Bakam, sebelah Selatan berbatasan dengan Desa Zed, Kecamatan Mendo Barat, sebelah Barat berbatasan dengan Desa Puding Besar, dan sebelah Timur berbatasan dengan Desa Sempan, Kecamatan Pemali. Jumlah penduduk sebanyak 1.946 jiwa, terdiri dari 1.033 orang laki-laki 913 orang perempuan terdiri dari 567 kepala keluarga. Pada awalnya, Desa Kayu Besi masih menjadi dusun, namun dalam perkembangan selanjutnya, berdasarkan Peraturan Daerah tentang Pembentukan, Penghapusan, dan Penggabungan Kelurahan yang berdasarkan Peraturan Pemerintah Nomor 12 Tahun 1984, maka pada tahun 1998 resmilah menjadi desa yang diberi nama Desa Kayu Besi. Menurut informasi dari salah satu tokoh masyarakat setempat bahwa beberapa tahun silam, sebelum Kayu Besi menjadi sebuah desa, wilayah tersebut masih berupa hutan rimba yang sangat lebat. Di wilayah tersebut hiduplah sebatang pohon yang tinggi menjulang berdiri kokoh.

Pada saat itu masyarakat bermaksud untuk menebang pohon tersebut, namun mereka pun dibuat heran olehnya, karena kayu yang ingin ditebang tidak tumbang melainkan parang dan kapak yang digunakan menjadi patah. Berbagai upaya telah dilakukan untuk menebangnya sampai puluhan tahun lamanya, namun seiring berjalannya waktu pada akhirnya kayu itu pun tumbang dengan sendirinya. ${ }^{82}$ Dari kejadian aneh itu pun dusun yang sebelumnya berupa hutan rimba yang lebat akhirnya pada tahun 1998 menjadi sebuah desa dan masyarakat sepakat untuk memberi nama Desa Kayu Besi, yang berarti kuat, teguh, dan kokoh. Berdasarkan pertimbangan yang telah ditetapkan maka visi Desa Kayu Besi adalah "Terciptanya masyarakat yang aman, kondusif, adil dan sejahtera melalui perkembangan sektor pertanian, perkebunan dan peningkatan pelayanan publik". Ada beberapa misi yang telah disepakati yaitu:

a. mengembangkan potensi ekonomi lokal secara berkelanjutan dan berwawasan,

b. meningkatkan kualitas SDM,

c. meningkatkan partisipasi masyarakat dalam pembangunan,

d. membangun sarana dan prasarana pendukung,

e. menciptakan kondisi dan lingkungan investasi yang kondusif,

f. meningkatkan kualitas dan kuantitas penyelenggaraan pemerintah dan pelayanan publik menuju sistem tata pemerintahan yang baik (good govermance). ${ }^{83}$

Pada umumnya, masyarakat desa terdiri dari satu atau beberapa kekerabatan saja, sehingga pola hidup tingkah laku maupun kebudayaan bersifat homogen. Oleh sebab itu, biasanya kehidupan di desa terasa tenteram, aman, dan tenang. Demikian itu dikarenakan pola bersikap, berpikir, dan berpandangan yang sama dari setiap warga dalam menghadapi suatu masalah. ${ }^{84}$ Adapun yang menjadi salah satu sifat masyarakat di desa tersebut adalah gotong royong yang mempunyai fungsi sosial. Dalam aktivitas gotong royong terdapat unsur tolong-menolong dan kebersamaan.

Dari unsur-unsur tersebut sudah tersirat adanya nilai sosial yang terkandung dalam kegiatan gotong royong. Keinginan untuk menolong dan rasa kebersamaan mencerminkan adanya kesadaran terhadap orang lain yang hidup bersama kita dan perlu dibantu. Pada hakikatnya itulah yang menyebabkan manusia bisa hidup bekerjasama dengan orang lain

\footnotetext{
81 Kuris, Tokoh Masyarakat, Wawancara ...

82 Kuris, Tokoh Masyarakat, Wawancara, Kediamannya di Desa Kayu Besi, 19 Januari 2020.

83 Data ini diambil dari profil Desa Kayu Besi tahun 2020.

84 Tom R. Burn, Manusia, Keputusan, Masyarakat (Jakarta: PT Pranadya Paramita Dandjaja, 1987), 271.
} 
atau lingkungan sekitarnya. Apalagi hal tersebut tidak hanya terjadi pada saat kegiatan gotong royong saja, akan tetapi dalam aktivitas sosial kemasyarakatan lainnya yang mengandung nilai-nilai religi seperti nganggung sepintu sedulang. ${ }^{85}$

Masyarakat Desa Kayu Besi semuanya menganut agama Islam. Desa tersebut memiliki satu masjid yang diberi nama Baitul 'Izzah dan dua musala yang terdapat di RT 03 dan RT 04. Masjid dan musala tersebut digunakan masyarakat sebagai tempat melaksanakan kegiatan keagamaan seperti salat secara berjemaah, majelis taklim (pengajian) dan perayaan hari-hari besar Islam, seperti mauludan, isra' mi'raj, tabligh akbar, dan sebagainya.

Di kalangan masyarakat Muslim Di Desa Kayu Besi terdapat berbagai kegiatan keagamaan. Kegiatan ini memiliki sebutan yang bermacam-macam sesuai hajat yang terkandung dalam kegiatan itu sehingga terdapat kegiatan maulid Nabi Muhammad SAW, isra' mi'raj, muharram, nishfu sya'ban (ruwahan), Hari Raya Idul Fitri, Hari Raya Idul Adha, nuzulul Qur'an, tujuh likor (27 hari bulan Ramadhan), tolak bala (10 Asyura), dan nujuh hari (7 hari kematian). Waktu pelaksanaan kegiatan tersebut secara garis besar terikat waktu tertentu. ${ }^{86}$

Respons masyarakat Muslim di Desa Kayu Besi terhadap kegiatan bimbingan keagamaan setidaknya hingga saat ini sangat antusias. Mereka memang suka mendengarkan bimbingan keagamaan terlepas serius ataupun sekadar ikut-ikutan. Kegiatan ini merupakan kegiatan masyarakat desa tersebut dalam bidang sosial keagamaan terkait dengan kajian-kajian Islam, baik yang diselenggarakan di masjid ataupun di rumah-rumah penduduk yang masih berlangsung hingga saat ini.

\section{Strategi Bimbingan Islam}

\section{A. Strategi Bimbingan Islam Guru Tua}

\section{Tujuan bimbingan}

Kegiatan bimbingan Islam yang dilaksanakan Guru Tua bertujuan mengabdikan dirinya untuk kemaslahatan masyarakat. Pengabdian diberikan selagi masih dibutuhkan masyarakat untuk membimbing mereka. Sebagai tokoh agama, Guru Tua tidak ingin serta merta langsung memberikan bimbingan kepada masyarakat tanpa adanya kesadaran dan keinginan pribadi dari masyarakat itu sendiri.

Menurut Guru Tua, tugas seorang tokoh agama awalnya mengajak orang lain untuk bersama-sama menuju jalan yang lebih baik. Apabila orang sudah secara senang hati diajak, barulah dibimbing. Sebaliknya, jika mereka tidak ingin diajak, jangan memaksakan ketidakinginan mereka serta jangan memandang rendah mereka. Sebab dalam agama ini tidak ada paksaan bagi penganutnya. Karena Allah SWT telah memberikan pilihan, barangsiapa yang ingin beriman dipersilahkan. Begitupun sebaliknya, barangsiapa yang tidak menginginkannya pun dipersilahkan. Namun, setiap pilihan itu pasti ada konsekuensinya ${ }^{87}$ Oleh sebab itu, ketika mereka bersenang hati dibimbing maka tujuannya adalah jadikan sebagai konfigurasi pengabdian untuk kemaslahatan orang banyak.

Lebih lanjut Guru Tua menjelaskan bahwa setiap orang memiliki permasalahan masingmasing, baik pribadi, keluarga, sosial masyarakat, dan agama. Permasalahan-permasalahan

85 Nganggung sepintu sedulang adalah salah satu budaya Bangka Belitung. Kegiatan tersebut adalah kegiatan yang melibatkan setiap orang yang hidup di suatu desa. Nganggung sepintu sedulang merupakan wadah yang berisi makanan untuk diberikan dan dimakan secara bersama dalam kegiatan keagamaan dan kemasyarakatan, seperti acara mauludan, tahlilan, mengelayat orang meninggal dunia, dan lain sebagainya.

86 Tamrin, Ketua Masjid, Wawancara ...

87 Guru Tua, Wawancara, Kediamanannya di Desa Kayu Besi, Kecamatan Puding Besar, Kabupaten Bangka, 11 Januari 2020. 
itu menuntut adanya penyelesaian. ${ }^{88}$ Untuk mendapatkan penyelesaian tersebut, sejatinya seseorang membutuhkan orang yang tepat dan dianggap mumpuni dalam menyelesaikannya. Tidak dapat disangkal bahwasanya beberapa orang datang kepada Guru Tua meminta solusi untuk menyelesaikan permasalahan yang dihadapi. Oleh sebab itu, dalam memberikan bimbingan kepada masyarakat tujuannya agar dapat mengeluarkan mereka dari permasalahan yang sedang dihadapi.

Pada dasarnya Guru Tua mengamati sikap masyarakat dan permasalahan-permasalahan yang berkembang dalam kehidupan mereka. Pengamatan itu terjadi saat Guru Tua berinteraksi dengan masyarakat. Ketika interaksi itu berlangsung, maka Guru Tua berupaya mengamati perubahan sikap-sikap mereka yang terkadang terlihat tidak wajar. Kemudian hal itu dipahami Guru Tua disebabkan suatu permasalahan yang mereka hadapi. Umumnya, perubahan sikap tersebut terlihat apabila sedang berinteraksi dengan mereka. Terkadang mereka yang memiliki permasalahan tidak begitu merespons dengan baik ketika berinteraksi sesama mereka dan hal semacam itu tidak seperti biasanya. Selain itu, Guru Tua mengamati permasalahan yang terjadi berdasarkan laporan masyarakat kepadanya.

Setelah penulis melakukan wawancara kepada masyarakat, diperoleh penjelasan bahwa ketika mereka memiliki permasalahan, baik sifatnya pribadi, keluarga, sosial masyarakat, terlebih pengetahuan agama, maka mereka pergi ke kediaman Guru Tua untuk meminta bimbingan kepadanya, agar mendapatkan pemahaman agama dan solusi untuk keluar dari permasalahan yang mereka hadapi. ${ }^{89}$ Kedatangan mereka ke kediaman Guru Tua berangkat dari kesadaran pribadi bukan karena keterpaksaan. Hal itu disebabkan mereka beranggapan bahwa Guru Tua adalah orang yang tepat dan memiliki kemampuan untuk memberikan bimbingan kepada mereka. Terlebih Guru Tua merupakan tokoh agama di desa mereka. Dengan demikian, tidaklah keliru jika meminta nasihat dan bimbingan kepada Guru Tua.

Beberapa anggota masyarakat mengatakan bahwa kegiatan bimbingan yang dilakukan oleh Guru Tua untuk kepentingan mereka tidak hanya dirasakan manfaatnya dalam kehidupan keagamaan dan ibadah saja, tetapi juga dalam kehidupan sosial, ekonomi, dan kultural (culture). ${ }^{90}$ Sehingga mereka memperlakukan Guru Tua dengan penuh hormat bukan saja sebagai tokoh agama, akan tetapi juga sebagai tokoh sosio-kultural yang menjadi panutan dalam kehidupan masyarakat sehari-hari.

\section{Metode bimbingan}

Pemberian bimbingan Islam kepada masyarakat dilaksanakan oleh Guru Tua dengan menggunakan dua metode, yaitu: individu dan kelompok. Guru Tua menjelaskan bahwasanya bimbingan yang dia laksanakan di tengah masyarakat ada yang sifatnya individu dan berkelompok. Hal itu dilakukan tergantung dari permasalahan yang terjadi pada diri seseorang. Bimbingan yang sifatnya pribadi diberikan atas permintaan seseorang yang datang ke kediamannya untuk meminta nasihat dan bimbingan terkait cara menyelesaikan permasalahan yang dihadapi. Adapun bimbingan yang sifatnya kelompok diberikan juga atas permintaan masyarakat yang ingin memahami suatu perkara agama, seperti teologi, fikih, akhlak, dan tasawuf. Mereka mengundang Guru Tua untuk memberikan bimbingan Islam kepada mereka dengan melakukan perkumpulan di salah satu rumah warga yang berada di desa tersebut.

\footnotetext{
88 Ibid.

89 Wawacara kepada masyarakat, 11 - 13 Januari 2020.

90 Ibid.
} 
Adapun penjelasan terkait metode pemberian bimbingan Islam oleh Guru Tua pada masyarakat pedesaan yaitu:

a. Individu

Dalam siklus kehidupan, problem akan didapati oleh setiap orang. Terlepas problem itu adalah permasalahan yang ringan atau bahkan rumit. Semua itu sejatinya mengharapkan adanya suatu penyelesaian. Meskipun demikian, setiap permasalahan yang sifatnya ringan bahkan rumit sekalipun pasti ada suatu cara untuk menyelesaikannya. Hal itu tergantung dari individu yang menghadapi permasalahan tersebut.

Guru Tua menjelaskan bahwa setiap orang yang hidup di dunia ini sejatinya mendapati ujian atau cobaan, baik sifatnya ringan maupun berat. Namun menghadapi hal itu, terkadang mampu diselesaikan oleh individu itu sendiri dan ada juga atas bantuan orang lain. Meskipun demikian, andaipun individu tersebut meminta bimbingan dari orang lain, maka hal itu juga tergantung dengan individu itu sendiri. Oleh sebab itu, sebagai pembimbing dituntut membantu untuk mengarahkan dirinya agar dapat keluar dari permasalahan yang dihadapi. Akan tetapi perlu digarisbawahi bahwasanya bantuan pembimbing diberikan atas dasar permintaan individu yang menghadapi permasalahan itu sendiri, bukan berarti pembimbing harus menawarkan diri untuk membantunya.

Masalah yang diajukan kepada Guru Tua dalam bimbingan secara individual berkaitan dengan permasalahan yang sifatnya pribadi, keluarga, sosial, dan agama. Permasalahan pribadi yang dimintai cara untuk menyelesaikannya adalah seputar masalah hinaan dari orang lain terhadap dirinya. Kemudian masalah keluarganya yang tidak harmonis, perselingkuhan dan perceraian. Selanjutnya permasalahan sosial yang acap kali dimintai solusi adalah terkait sosial keagamaan, sosial politik, dan masyarakat. Selain itu, permasalahan yang juga sering kali dimintai bimbingan adalah seputaran permasalahan agama.

Ketika hal tersebut penulis tanyakan kepada anggota bimbingannya, ternyata yang paling dirasakan saat mengalami suatu masalah adalah perasaan gelisah. Kegelisahan tersebut mengakibatkan hati yang tidak tenang dan akhirnya berdampak dengan psikologisnya. Hal tersebut membuktikan kebenaran bahwasanya masyarakat sebagai manusia, sejatinya akan mendapati problem dalam kehidupannya. ${ }^{91}$ Oleh sebab itu, kehadiran Guru Tua di tengah masyarakat Desa Kayu Besi, turut andil dalam membantu penyelesaian masalah yang dihadapi oleh masyarakat.

Selain itu, dalam bimbingan secara individu penulis mendapat pengakuan dari anggota bimbingan bahwa permasalahan yang mereka meminta solusi dari Guru Tua adalah permasalahan keharmonisan keluarga mereka yang mulai tidak baik. Pada tahun awal pernikahannya, kehidupan keluarga tergolong harmonis sampai memiliki beberapa orang anak yang semakin tumbuh berkembang menjadi remaja. Akhirnya keharmonisan berubah menjadi pertengkaran, ditambah tingkah laku anak-anaknya yang seringkali memicu emosi. Sehingga demikian itu menjadikan suasana rumah terasa tidak tenang. Mereka pun pergi ke kediaman Guru Tua dan bertanya terkait permasalahan yang dialami. Pertanyaan tersebut dilayangkan kepada Guru Tua terkait, mengapa mereka berdua mudah sekali emosional dan akhirnya bertengkar, serta kejadian itu terjadi setiap harinya? Bagaimana cara mereka menghadapi kelakuan anak-anak mereka yang sangat menjengkelkan? Mengapa setiap kali mereka berada di dalam rumah, acap kali mereka merasakan tidak nyaman dan selalu gelisah?

\footnotetext{
91 Wawacara kepada anggota bimbingan, 12 - 14 Januari 2020.
} 
Mendengar permasalahan yang diajukan tersebut, Guru Tua menjelaskan bahwa masalah yang diajukan kepadanya sangat dibutuhkan penyelesaiannya. Namun, anggota bimbingan yang terkena masalah tersebut juga harus mampu bekerja sama, karena apabila Guru Tua sudah memberikan bimbingan, maka berhasil atau tidaknya, tentunya berada pada anggota bimbingan itu sendiri. Setelah kesepakatan antara Guru Tua dan anggota bimbingan terjalin baik, maka Guru Tua melakukan bimbingan. Guru Tua pun mencoba menggali akar permasalahan yang terjadi di keluarga tersebut. Setelah permasalahan tersebut diketahui penyebabnya, maka Guru Tua membangun kesadaran mereka akan kekeliruan, kekurangan, dan kesalahan selama ini yang menjadikan terjadinya masalah dalam keluarga tersebut.

Setelah pengakuan dan kesadaran mereka utarakan dengan sepenuh hati, maka bimbingan dilakukan Guru Tua dengan menjelaskan pengajaran Islam dalam membimbing kehidupan agar menjadi keluarga yang tenteram dan tenang. Dalam kegiatan tersebut, Guru Tua menyampaikannya dengan lembut tanpa harus terlihat sedang mengajari mereka. Sehingga hal itu menambahkan kedekatan antara Guru Tua dan anggota bimbingannya dan memudahkan dalam penyelesaian masalah yang dihadapi.

Setelah penulis melakukan penelusuran lebih lanjut, dapat penjelasan bahwa Guru Tua memberi kesempatan kepada anggota bimbingan untuk mendayagunakan sendiri kemampuan yang telah dimiliki dalam upaya memperbaiki kondisi kehidupan rumah tangga dan mental mereka. ${ }^{92}$ Selanjutnya, bimbingan dilakukan beberapa kali, sekaligus melakukan evaluasi terhadap keefektifannya. Sehingga hal itu dilakukan Guru Tua sampai keadaan rumah tangga mereka tenang kembali. Apabila keadaan rumah tangga mereka sudah tenang tanpa ada keributan, maka Guru Tua memberikan bimbingan guna untuk menghindari permasalahan tersebut terulang kembali.

b. Kelompok

Bimbingan yang diberikan Guru Tua kepada masyarakat juga bersifat kelompok. Guru Tua menjelaskan bahwa bimbingan secara kelompok diberikan kepada beberapa orang yang meminta dirinya untuk memberikan pemahaman keagamaan kepada mereka. Bimbingan kelompok yang dilakukan oleh Guru Tua memiliki dua model, yaitu kelompok kecil (7 - 12 orang) dan kelompok besar (30 - 40 orang).

Bimbingan kepada kelompok kecil dilaksanakan di kediaman Guru Tua dan Musala Desa Kayu Besi. Anggota bimbingan yang ikut dalam bimbingan tersebut adalah anak-anak muda. Mereka meminta Guru Tua untuk memberikan bimbingan Islam. Hal itu bertujuan agar mereka dapat menikmati masa mudanya dengan hal-hal yang positif. Selain itu, tidak jarang selesai bimbingan Guru Tua diberikan, mereka acap kali menanyakan permasalahan yang berkisar masalah pribadi dan sosial. Mereka meminta solusi dan pendapat Guru Tua terkait permasalahan yang mereka hadapi.

Melihat demikian itu, penulis langsung bertanya kepada anggota bimbingan Guru Tua, mengenai manfaat dari kegiatan bimbingan tersebut. Alhasil, penulis mendapatkan penjelasan dari anggota bimbingan bahwa mereka semakin mendapatkan ilmu pengetahuan, sehingga lebih memahami diri dan problematika yang dihadapi. Tidak hanya itu, anggota bimbingan pun merasa bahwa keimanan mereka meningkat, keteguhan pendirian, dan ketakwaan. Sehingga hal itu memungkinkan dapat mencegah timbulnya kembali permasalahan dalam kehidupan.

Selain anggota bimbingan, masyarakat pun merasakan hal positif dan memperoleh keilmuan yang sangat berguna. Demikian itu didapatkan pada saat Guru Tua dimintai masyarakat untuk memberikan ceramah agama dalam acara keagaamaan, mengisi khotbah,

\footnotetext{
92 Observasi kegiatan bimbingan Islam Guru Tua, 12 Januari 2020.
} 
dan menasihati pengantin. Di samping memperkaya khazanah keilmuan Islam pada masyarakat, hal itu pun menambah kemampuan dalam introspeksi diri, serta membina kehidupan masyarakat yang tenteram.

Adakalanya Guru Tua diundang oleh masyarakat dalam acara tahlilan, syukuran, maulidan, dan hajatan. Guru Tua diminta untuk memberikan bimbingan keagamaan, seperti nasihat perkawinan, nasihat bagi jemaah haji dan lain sebagainya. Tidak jarang pula, Guru Tua diminta untuk memimpin doa. Kesempatan tersebut digunakan Guru Tua untuk memberikan ilmu pengetahuan dan arahan kapada masyarakat. Beberapa masyarakat menegaskan bahwa mereka memandang Guru Tua sebagai sumber ilmu pengetahuan keagamaan, yang tidak hanya memberikan pengetahuan teoretis, akan tetapi juga secara praktis. Dengan demikian, masyarakat tidak hanya merasa manfaat kecerdasan pikiran, namun dapat juga manfaat kecerdasan batiniah. Oleh sebab itu, keberadaan Guru Tua membuat masyarakat merasa terbimbing dalam kehidupannya, baik dalam bidang ibadah dan keagamaan, namun juga dalam aktivitas mereka dalam kehidupan sosial masyarakat.

\section{Materi bimbingan}

Materi yang disampaikan Guru Tua sangat mudah dipahami. Hal itu disebabkan penyampaiannya yang lembut dan tertata, sehingga materi tersebut semakin membuat masyarakat mudah untuk memahaminya. Guru Tua juga mampu merangkul semua kalangan masyarakat, baik anak-anak, remaja, dan orang dewasa. Tidak hanya itu, materi yang disampaikan oleh Guru Tua juga tidak memberatkan masyarakat dan dia juga orangnya senang diajak curhat. Curhat sama Guru Tua tersebut membuat masyarakat merasa nyaman. Demikian itu disebabkan Guru Tua memahami keadaan masyarakat, serta mencurahkan hati kepadanya sesuai dengan harapan masyarakat yang menuntut adanya penyelesaian atas permasalahan-permasalahan yang mereka hadapi.

Dalam memberikan bimbingan Islam kepada masyarakat, Guru Tua menggunakan dua materi, yaitu: materi tugas dan bebas.

a. Materi tugas

Guru Tua menjelaskan bahwa dalam memberikan bimbingan Islam, dia menggunakan beberapa kitab. Kitab tersebut digunakan sesuai dengan permintaan dari anggota bimbingan. Bimbingan Islam pada kelompok kecil, Guru Tua diminta untuk memberi materi tentang fikih salat. Meskipun demikian, Guru Tua tidak langsung menentukan materinya, akan tetapi dia menanyakan kepada anggota bimbingan, hal apakah yang ingin dicapai dan dipahami dari materi tersebut.

Anggota bimbingan menginginkan dari materi yang diberikan dapat memberikan pemahaman keagamaan dan dorongan motivasi agar dapat lebih semangat dalam mengerjakan salat. Setelah itu, Guru Tua menawarkan salah satu kitab klasik yang berjudul Asroris Sholah min 'Iddati Kutubil Mu'tamidati karangan Syaikh Abdurrahman Siddik AlBanjari, yang menerangkan rahasia-rahasia di balik pelaksanaan salat. Kemudian anggota bimbingan melakukan diskusi dengan rekan lainnya dan mereka pun sepakat dengan materi yang akan diberikan dengan menggunakan kitab tersebut.

Pada kelompok besar, anggota bimbingan meminta Guru Tua untuk memberikan materi terkait tentang ketuhanan (theology). Tujuannya, agar mereka memahami esensi ketuhanan dan meningkatkan ketakwaan mereka dalam beribadah kepada Allah SWT. Mendengar permintaan dari anggota bimbingan, Guru Tua pun menawarkan kitab 'Aqoidul Iman karangan Syaikh Abdurrahman Siddik Al-Banjari. Tawaran Guru Tua pun akhirnya disepakati oleh anggota bimbingan. 
Berkenaan dengan hal itu, Guru Tua menjelaskan bahwa dirinya tidak ingin memberikan materi bimbingan Islam kepada masyarakat jika hanya berangkat dari keinginan pribadinya. Sebab yang mengetahui permasalahan yang terjadi pada diri seseorang adalah dirinya sendiri. Oleh sebab itu, Guru Tua menampung aspirasi anggota bimbingannya dan baru selanjutnya melakukan musyawarah agar mendapatkan kesepakatan bersama.

Selain dari kitab tersebut, Guru Tua juga menggunakan beberapa kitab yang disesuaikan dengan tujuan anggota bimbingan untuk memahaminya. Dalam materi tugas, Guru Tua juga diminta untuk memberikan materi fikih, tauhid, dan tasawuf. Adapun kitab-kitab yang digunakan dan disepakati bersama, sebagai berikut:

1) Bidang fikih salat menggunakan kitab Asroris Sholah min 'Iddati Kutubil Mu'tamidati karangan Syaikh Abdurrahman Siddik Al-Banjari.

2) Bidang tauhid menggunakan beberapa kitab yaitu: 'Aqoidul Iman karangan Syaikh Abdurrahman Siddik Al-Banjari, Nurul Jalal fi Ma'rifatillah Dzil Jalal yang dikarang oleh Tuan Guru Zahruddin Asahan, dan Tuhfah al-Raghibin fi Bayani Haqiqah Iman al-Mu'minin wa ma Yufsiduhu Riddah al-Murtaddin karya Syaikh Muhammad Arsyad al-Banjari.

3) Bidang tasawuf menggunakan kitab al-Yawaqit wal Jawahir fi 'Uqubat Ahlil Kabair karangan Syaikh Muhammad 'Ali bin 'Abdul Rashid al-Jawi.

b. Materi bebas

Kegiatan bimbingan Islam yang diberikan oleh Guru Tua tidak hanya membahas materimateri yang berasal dari kitab-kitab. Hal itu terlihat setelah penulis melakukan penelusuran bahwa ternyata bimbingan yang dilaksanakan juga membahas materi bebas. Materi bebas yang dimaksudkan adalah materi yang menjadi problem pada kehidupan anggota bimbingan dan masyarakat, baik problem pribadi, keluarga, sosial masyarakat, dan khususnya agama.

Guru Tua menegaskan bahwa dalam kegiatan bimbingannya juga tidak jarang permasalahan-permasalahan yang dialami oleh anggota bimbingan dibahas di dalamnya. Hal itu bagian terpenting untuk diperhatikan, mengingat terkadang suasana hati seseorang pastilah berubah-ubah. Oleh sebab itu, Guru Tua membebaskan bahasan materi guna untuk menambah semangat para anggota bimbingan agar mereka tidak merasa jenuh.

Permasalahan yang sering diajukan kepada Guru Tua adalah permasalahan yang dialami oleh anggota bimbingan, seperti permasalahan pribadi, keluarga, sosial, dan agama. Mereka meminta solusi agar dapat keluar dari permasalahan tersebut. Ketika penulis mencoba bertanya kepada mereka terkait alasan membahas permasalahan kehidupan, maka didapatkan penjelasan bahwa saat mendapatkan permasalahan mereka tidak tahu cara untuk mengatasinya. Oleh sebab itu, mereka meminta pengarahan kepada Guru Tua untuk dapat menyelesaikan permasalahan tersebut.

\section{Pelaksanaan bimbingan}

Adapun proses pelaksanaan bimbingan Islam Guru Tua melewati beberapa tahapan, yaitu: pembentukan, peralihan, kegiatan, pengakhiran, dan evaluasi.

a. Pembentukan

Bimbingan Islam yang dilaksanakan Guru Tua dibentuk secara informal (tidak resmi). Demikian itu berawal dari banyaknya masyarakat yang datang ke rumahnya meminta pendapat dan solusi terkait permasalahan yang dihadapi. Guru Tua menjelaskan bahwa beberapa masyarakat datang ke kediamannya untuk menanyakan hukum-hukum Islam dan meminta penyelesaian atas masalah yang mereka hadapi. Setelah itu, karena semakin banyaknya yang datang, mereka pun meminta untuk memberikan bimbingan terkait masalah keislaman di rumah-rumah warga. 
Pernyataan Guru Tua pun ditegaskan oleh anggota bimbingan bahwa mereka secara pribadi datang ke rumah Guru Tua menceritakan berbagai masalah yang mereka hadapi, baik sifatnya individu, keluarga, sosial, dan khususnya agama. Pembentukan tersebut pun tanpa disengaja atau secara tidak resmi. Maka dari itu, dikarenakan banyaknya masyarakat yang ingin memahami ajaran Islam, sehingga mereka pun berinisiatif untuk membentuk kelompok bimbingan tersebut. Alhasil, bimbingan yang mereka laksanakan tetap berjalan dengan baik sampai saat ini.

b. Peralihan

Setelah kelompok bimbingan terbentuk, Guru Tua pun diminta untuk menjadi pembimbing mereka. Kemudian mereka membuat kesepakatan bersama terkait hal itu. Guru Tua menanyakan terlebih dahulu hal apa yang ingin mereka dapatkan dari kegiatan tersebut. Perkara itu dipertanyakan sebab Guru Tua tidak ingin kegiatan bimbingan tersebut dilaksanakan tanpa kejelasan pasti. Sebab bimbingan akan terbina secara optimal, tergantung kesepakatan antara pembimbing dan anggota bimbingan.

Ketika penulis menanyakan kepada anggota bimbingan, maka diperoleh penjelasan bahwa setelah dibentuknya kelompok bimbingan, mereka pun melakukan musyawarah sesama anggota terkait orang yang akan membimbing. Dari hasil musyawarah yang dilakukan, mereka pun sepakat meminta Guru Tua untuk memberikan bimbingan tersebut. Kemudian terjadilah kesepakatan antara Guru Tua dan anggota bimbingan dan menentukan materi yang ingin dipahami secara bersama.

Lebih lanjut Guru Tua mengungkapkan bahwa dirinya sangat mengapresiasi keinginan masyarakat yang ingin memahami ajaran Islam. Meskipun demikian, dirinya menyerahkan sepenuhnya kepada anggota bimbingan dengan melakukan musyawarah bersama agar mendapatkan kesepakatan. Hal itu dilakukan agar tidak muncul keraguan dan ketidaksiapan anggota bimbingan dalam mengikuti kegiatan tersebut.

c. Kegiatan

Kegiatan bimbingan Guru Tua yang sifatnya individu, dilakukan secara tertutup atau rahasia. Hal itu dilakukan agar permasalahan yang sifatnya pribadi tidak diketahui orang lain. Menurut hemat penulis, dalam bimbingan secara individu sudah seharusnya pembimbing tidak membuka permasalahan yang dialami anggotnya. Mengingat adanya asas kerahasiaan yang perlu dijaga dan disepakati bersama. Guru Tua menjelaskan bahwa ketika seseorang memiliki permasalahan pribadi, maka dirinya sering didatangi untuk dimintai arahan dan bimbingan agar individu tersebut dapat keluar dari permasalahan mereka. Oleh sebab itu, yang namanya permasalahan pribadi sejatinya tidak boleh diceritakan kepada orang lain. Karena demikian itu merupakan aib seseorang yang musti dijaga dengan sebaikbaiknya.

Setelah penulis melakukan penelusuran, maka terlihat seseorang pergi meminta bimbingan kepada Guru Tua. Mereka meminta bimbingan agar dapat mengatasi permasalahan yang dihadapi. Ketika penulis mencoba bertanya kepada istri Guru Tua, dia mengonfirmasikan bahwa rumahnya memang jarang sekali terlihat sepi. Bahkan terkadang Guru Tua kedatangan banyak tamu, mulai dari malam sampai subuh. Meskipun demikian, Guru Tua tetap menyikapi hal tersebut dengan penuh syukur. Hal itu tampak terlihat dari sikap Guru Tua yang tidak pernah mengeluh tentang keadaan tersebut.

Selain itu, dalam pelaksanaan kegiatan bimbingan yang sifatnya kelompok, Guru Tua terlebih dahulu memberikan materi yang sudah disepakati bersama. Materi bimbingan dibahas oleh Guru Tua selama 30 menit. Setelah materi disampaikan, maka Guru Tua mempersilahkan kepada anggota bimbingan untuk memberikan pertanyaan atau membuka ruang bagi anggota untuk membahas masalah lain. Hal itu ditegaskan oleh anggota 
bimbingan, bahwa setelah materi dibahas, Guru Tua memberikan kesempatan kepada para anggota bimbingan agar bisa bertanya mengenai permasalahan yang telah dibahas atau membicarakan permasalahan yang dihadapi oleh mereka.

Ketika penulis menelusuri kegiatan tersebut, ternyata didapati penjelasan bahwa anggota bimbingan tidak hanya menanyakan materi yang telah dibahas oleh Guru Tua. Akan tetapi, mereka juga meminta arahan dari Guru Tua terkait masalah yang sifatnya pribadi, keluarga, sosial, dan keberagamaan. Anggota bimbingan pun mengonfirmasikan, memang seringkali mereka membahas permasalahan yang dihadapi oleh sesama anggota. Setelah itu, mereka memberikan pandangan masing-masing dan mencari jalan untuk mengatasi permasalahan yang dihadapi.

d. Pengakhiran

Pada tahap ini terdapat dua kegiatan yaitu penilaian (evaluasi) dan tindak lanjut (follow up). Tahap ini merupakan tahap penutup dari serangkaian kegiatan bimbingan yang telah dilaksanakan oleh Guru Tua dengan menjelaskan bahwa kegiatan akan segera diakhiri. Setelah itu, mereka mengemukakan pesan dan kesan dari hasil kegiatan, membahas kegiatan lanjutan dan kemudian mengemukakan pesan dan harapan.

Masyarakat yang Muslim terutama anggota bimbingan memiliki harapan dan kesan sendiri terkait dengan bimbingan yang dilaksanakan. Pada umumnya para anggota menginginkan penguasaan materi keislaman secara baik dan benar. Dalam hal ini ditegaskan oleh anggota bimbingan bahwa mereka mengikuti bimbingan Guru Tua dengan mengharapkan agar mereka lebih bisa memahami kaidah-kaidah Islam dan lebih giat lagi dalam menjalani kehidupan dengan penuh kedamaian. Mereka sangat membutuhkan pengajaran-pengajaran terkait permasalahan keislaman. Mereka juga mengharapkan agar materi yang berada dalam sosial kemasyarakatan bisa dikaji dengan menggunakan pandangan Islam.

e. Evaluasi

Pada tahapan ini Guru Tua melakukan evaluasi dengan cara menanyakan materi yang telah dibahas. Apakah sudah paham ataupun belum. Jika belum paham maka materi tersebut akan dibahas di pertemuan selanjutnya. Hal itu dilakukan agar para anggota bimbingan benar-benar paham dengan materi yang dibahas.

Guru Tua menegaskan bahwa setiap melaksanakan bimbingan, hal yang harus diperhatikan adalah tahap selanjutnya yaitu evaluasi. Hal tersebut harus ada dalam pelaksanaan bimbingan, karena melalui evaluasi, pembimbing bisa mengetahui tingkat pemahaman para anggota bimbingan, apakah mereka sudah benar-benar memahami ataupun tidak sama sekali. Oleh karena itu, evaluasi ini bisa menjadi alat ukur bagi para pembimbing agar bisa melihat sejauh mana tingkat keberhasilan pelaksanaan bimbingan. Tidak hanya itu, tahapan evaluasi pun digunakan untuk mengenali kemajuan positif yang terjadi pada diri anggota bimbingan dengan menganalisis dan menindaklanjuti proses kegiatan tersebut. Sebagaimana ditegaskan oleh Guru Tua bahwa setelah melakukan bimbingan kelompok. Mereka melakukan diskusi untuk mengetahui sejauh mana proses pemberian bantuan telah dicapai dan anggota pun diminta untuk menyampaikan pendapat, perasaan, harapan, dan minatnya terhadap berbagai hal terkait kegiatan yang telah dilaksanakan.

Anggota bimbingan juga mengungkapkan bahwa setelah mereka melaksanakan kegiatan bimbingan Islam, Guru Tua memberikan kami kesempatan untuk mengungkapkan perasaan, saran, serta pendapat. Hal itu dilaksanakan untuk mengembangkan kegiatan bimbingan agar bisa tetap menunjukkan eksistensinya dan diminati oleh para anggota bimbingan. Oleh sebab itu, mereka sangat terbantu dengan kegiatan evaluasi tersebut, karena mereka bisa 
sharing untuk mengembangkan kegiatan tersebut agar lebih mendapatkan hasil yang baik dan membanggakan.

\section{Unsur-unsur dalam bimbingan}

Kegiatan bimbingan yang mereka laksanakan secara kelompok selalu menekankan unsurunsur penting di dalamnya, meliputi dinamika kelompok, pemimpin kelompok dan anggota kelompok.

a. Dinamika

Dalam kegiatan tersebut terjadi interaksi yang aktif yang dilakukan oleh Guru Tua terhadap anggotanya. Hal tersebut dia lakukan untuk mencapai suatu tujuan yang baik. Guru Tua menegaskan bahwa keberhasilan bimbingan Islam, baik secara individu dan kelompok akan tercapai apabila terjadi interaksi antar anggotanya. Oleh sebab itu, di samping dirinya menjelaskan materi kepada anggotanya, dia pun menyelingi dengan berinteraksi secara langsung kepada anggotanya. Tujuannya agar tercapai kekompakan antar anggota bimbingannya dan supaya mereka tetap mengikuti setiap kegiatan bimbingan. Hal tersebut juga diungkapkan oleh para anggota bimbingan bahwa setiap kegiatan bimbingan berlangsung, Guru Tua selalu memberikan kesempatan bagi mereka untuk saling mendiskusikan perihal kegiatan yang dilaksanakan. Dengan tujuan agar menimbulkan kekompakan di antara mereka.

b. Pembimbing

Pembimbing harus profesional dalam melaksanakan layanan bimbingan Islam. Hal tersebut dikarenakan, berhasil tidaknya suatu bimbingan secara individu dan kelompok tergantung bagaimana cara pembimbing dalam mengendalikan dirinya serta mengetahui porsi (bagian) dalam melaksanakan bimbingan dengan sebaik-baiknya. Hal ini juga ditegaskan oleh anggota bimbingan bahwa untuk melaksanakan bimbingan sudah seharusnya terdapat pembimbing, karena seorang pembimbing itu dituntut untuk bisa mengatur jalannya bimbingan.

Dari paparan di atas dapat dipahami bahwa keberadaan seorang pembimbing itu sangat diperlukan. Hal itu dikarenakan, pembimbing adalah orang yang sangat berperan penting dalam keberhasilan dan mengatur jalannya proses bimbingan tersebut. Oleh karena itu, keberadaan pembimbing yang profesional sangat dibutuhkan.

c. Anggota bimbingan

Anggota dalam kegiatan bimbingan Islam Guru Tua sangat aktif dan membantu terbinanya keakraban di antara keduanya. Mereka mampu berkomunikasi secara terbuka dan berusaha membantu anggota lain yang sedang dihadapi masalah. Guru Tua menegaskan bahwa anggota bimbingan sangat memiliki peranan penting dalam kegiatan bimbingannya, tanpa anggota bimbingan dapat dipastikan kegiatan bimbingannya tidak akan terlaksana. Hal ini juga ditegaskan oleh anggota bimbingan bahwa mereka sangat aktif dalam menyelesaikan permasalahan yang dihadapi oleh rekan-rekan anggota dalam kegiatan bimbingan tersebut.

\section{Teknik bimbingan}

Teknik yang digunakan dalam bimbingan Islam Guru Tua adalah teknik umum. Teknik tersebut diberikan dengan menggunakan komunikasi secara bebas dan terbuka. Hal tersebut diungkapkan oleh Guru Tua bahwa hal yang terpenting untuk melaksanakan bimbingan adalah bahasa yang digunakan. Dengan kalimat lain, pembimbing harus memilih kata-kata ataupun kalimat-kalimat yang menumbuhkan suasana komunikatif. Selanjutnya pembimbing harus menyampaikan pesan-pesan bimbingan secara sistematis (teratur) dan 
penuh semangat. Pembimbing juga harus mengatur intonasi suara secara bergelombang (mengombinasi intonasi suara antara yang rendah, sedang, dan tinggi) sesuai dengan karakteristik materi bimbingan yang akan disampaikan. Komunikasi yang dilaksanakan oleh Guru Tua adalah komunikasi langsung dan dua arah secara tatap muka. Di mana setelah dia memberikan materi, maka anggota kelompok pun merespons dengan cara bertanya terkait masalah pribadi, keluarga, agama, serta sosial. Komunikasi yang dilaksanakan pun tergolong berhasil di mana para anggota kelompok bimbingan memahami esensi bimbingan dengan baik dan benar. Sebagaimana ditegaskan oleh anggota bimbingan bahwa komunikasi yang digunakan oleh Guru Tua sangat menarik. Mereka dengan cepat menangkap setiap materi yang disampaikan. Mereka juga menambahkan bahwa bahasa dalam komunikasi Guru Tua sangat komunikatif.

Dari paparan singkat di atas dapat dipahami bahwa komunikasi yang dilaksanakan adalah komunikasi dua arah. Dengan artian bahwa ketika komunikator menyampaikan materi, maka terdapat umpan balik ataupun respons dari para anggota bimbingan. Komunikasi yang digunakan Guru Tua tergolong efektif dengan menggunakan bahasa yang mudah dipahami oleh para anggota bimbingan. Guru Tua memberikan penjelasan dan contoh agar lebih dipahami oleh anggotanya, serta selalu memberikan semangat kepada mereka.

\section{Strategi Bimbingan Islam Ustaz Muda}

\section{Tujuan bimbingan}

Kegiatan bimbingan Islam yang diberikan Ustaz Muda bertujuan untuk memberikan pemahaman keislaman kepada masyarakat. Ustaz Muda menjelaskan bahwa tujuannya dalam memberikan bimbingan Islam adalah ingin agar masyarakat memahami ajaran Islam secara baik dan benar. Hal itu diberikan sebab dirinya berasumsi bahwa masih banyak orang yang belum memahami ajaran Islam secara baik dan benar. Oleh sebab itu, sudah menjadi kewajiban dirinya sebagai ustaz untuk memberikan kontribusi keilmuan agar menambah wawasan ilmu pengetahuan tentang Islam di kalangan masyarakat, khususnya di pedesaan. ${ }^{93}$

Lebih lanjut Ustaz Muda menjelaskan bahwa sebagai pembimbing dirinya memiliki kewajiban untuk menyampaikan ajaran Islam, walaupun hanya sekadar satu ayat. Pembimbing dituntut menyampaikan ajaran Islam secara kaffah (sempurna) dan mengatakan dengan sebenarnya. Sebagaimana anjuran dari Nabi Muhammad SAW, sampaikanlah kebenaran dengan sebenar-benarnya meskipun harus mendapatkan konsekuensi yang negatif dari orang lain. Sebagai pembimbing, dirinya sudah siap menerima konsekuensi tersebut. Karena menurutnya, dalam memberikan bimbingan Islam kepada masyarakat tentunya pasti ditemukan sikap menerima dan menolak ajaran disampaikan. Meskipun demikian, dirinya tetap tidak memendam rasa kebencian kepada mereka yang menolaknya.

Ketika penulis melakukan wawancara kepada anggota bimbingan, maka didapati penjelasan bahwa tujuan mereka ingin mengikuti bimbingan Islam yang dilaksanakan oleh Ustaz Muda adalah untuk memahami dan mendalami ajaran agama. Hal itu dikarenakan mereka merasa bahwa belum mendalami ajaran Islam dengan baik dan benar. ${ }^{94}$ Oleh sebab itu, mereka menyempatkan hadir untuk mengikuti bimbingan tersebut guna mendapatkan pemahaman tentang ajaran Islam.

\section{Metode bimbingan}

93 Ustaz Muda, Wawancara, Kediamannya di Desa Kayu Besi, Puding Besar, Bangka, 27 Desember 2019.

94 Wawancara kepada anggota bimbingan, 04 Januari 2020. 
Pemberian bimbingan Islam yang dilaksanakan Ustaz Muda adalah secara kelompok. Ada beberapa kelompok dalam bimbingannya, yaitu: kelompok bapak-bapak, ibu-ibu, dan remaja. Anggota yang mengikuti bimbingannya terdiri dari kelompok kecil dan besar. Pada kelompok kecil diikuti 4 - 12 orang dan kelompok besar diikuti 20 - 40 orang. Pada kegiatan kelompok tersebut, Ustaz Muda memberikan materi dengan menggunakan kitab yang dia anggap perlu untuk disampaikan kepada masyarakat di pedesaan.

Ustaz Muda menjelaskan bahwa kegiatan bimbingan yang dilaksanakannya dengan cara berkelompok. Sengaja dirinya membedakan antara kelompok bapak-bapak, ibu-ibu, dan remaja. Hal itu disebabkan keinginannya agar materi yang disampaikan dapat dipahami oleh anggota bimbingannya. Dalam bimbingan tersebut, Ustaz Muda menyampaikan materi terkait ketauhidan, fikih, dan tasawuf.

Setelah penulis melakukan wawancara kepada anggota bimbingan, maka dapat diketahui bahwa mereka mengikuti kegiatan bimbingan Ustaz Muda, karena ingin mendalami ilmu agama. Dalam kelompok tersebut dipisahkan antara bapak-bapak, ibu-ibu, dan remaja. Mengingat agar lebih dapat menyimak dengan baik materi yang diberikan oleh Ustaz Muda.

\section{Materi bimbingan}

Materi yang dibahas dalam bimbingan Ustaz Muda adalah materi tugas. Materi tugas diberikan adalah materi dari kitab-kitab. Dalam hal ini, Ustaz Muda menjelaskan bahwa dalam pemberian bimbingan Islam, dia menggunakan kitab. Demikian itu dimaksudkan agar masyarakat memahami ajaran Islam dari rujukan yang jelas. Adapun kitab-kitab yang digunakan sebagai materi yaitu:

a. Kitab Syarah Hadits Jibril karangan Habib Zein bin Ibrohim bin Smith.

b. Kitab I'anah at-Tholibin karangan Syaikh Ali bin Abdullah bin Mahmud bin Syaikh Muhammad Arsyad al-Banjari.

c. Kitab Riyaadhus Sholihin karangan Syaikh Imam an-Nawawie

d. Kitab Bidayatul Hidayah karangan Imam al-Ghozali

e. Kitab 'Aqoidul Awam karangan Sayid Ahmad al-Marzuki

f. Kitab Tafsir Jalalain karangan Imam Jalaluddin as-Suyuthi dan Imam Jalaluddin alMahalli.

Dalam kegiatan bimbingan yang dilaksanakan Ustaz Muda materi yang disampaikan terkait tentang tauhid, fikih, dan akhlak. Dalam hal ini, Ustaz Muda menjelaskan pemberian materi tentang ketuhanan, fikih, dan akhlak adalah upaya dasar dan utama dalam proses bimbingan Islam yang dilakukan agar masyarakat dapat memahami agama dengan baik dan benar. Hal tersebut dilakukan Ustaz Muda untuk meningkatkan kualitas keimanan dan ketakwaan masyarakat kepada Allah SWT, serta meningkatkan keinginan masyarakat untuk mengamalkan ajaran Islam dalam seluruh aspek kehidupan sehari-hari secara konsisten.

Setelah penulis melakukan wawancara kepada anggota bimbingan, diperoleh penjelasan bahwa dalam menyampaikan materi bimbingan Islam kepada masyarakat, Ustaz Muda menyampaikannya dengan suara yang lantang dan tegas. Ustaz Muda pun menyampaikan materi dengan menggunakan kitab, sebab dirinya ingin masyarakat memahami ajaran Islam secara baik dan benar. Oleh sebab itu, materi yang disampaikan melalui beberapa kitab yang telah dipelajari dan pahami dari pondok pesantrennya dulu. Demikian itu dikarenakan Ustaz Muda tidak ingin masyarakat memahami ajaran Islam dengan menggunakan kitab yang dipertanyakan kejelasannya. Mengingat hal itu dapat memicu kesalahpahaman masyarakat dalam mempelajari Islam secara baik dan benar. 


\section{Pelaksanaan bimbingan}

Dalam kegiatan bimbingan yang dilaksanakan Ustaz Muda memiliki beberapa proses, yaitu: pembentukan, peralihan, dan kegiatan.

a. Pembentukan

Bimbingan Islam yang dilaksanakan Ustaz Muda pada masyarakat pedesaan terbentuk secara formal (resmi). Ustaz Muda menjelaskan bahwa bimbingan yang dilaksanakannya dibentuk untuk memberikan pemahaman agama kepada masyarakat. Hal itu dilakukan mengingat tugas seorang tokoh agama sejatinya mendedikasikan kehidupannya untuk kemaslahatan orang banyak. Oleh sebab itu, dirinya berinisiatif membentuk beberapa majelis taklim. Adapun majelis-majelis tersebut, yaitu:

1) Majelis Taklim Riyaadhul Jannah

Majelis ini terbentuk pada tahun 2007. Alasan majelis taklim tersebut terbentuk karena dirinya melihat banyak perempuan-perempuan di Desa Kayu Besi yang tidak menggunakan jilbab. Oleh sebab itu, dia mengajak beberapa ustaz di desa tersebut untuk membuka majelis taklim. Alhasil, majelis tersebut pun terbentuk dan diberi nama Riyaadhul Jannah yang berarti taman surga. Majelis ini diikuti beberapa orang anak muda, yang mana mereka mempelajari ilmu tauhid, fikih, dan akhlak. Setelah beberapa tahun kemudian, tepatnya pada tahun 2009, majelis tersebut berubah menjadi pondok pesantren dan dinamai Pondok Pesantren Riyaadhul Jannah yang diasuh oleh Ustaz Muda.

2) Majelis bapak-bapak

Majelis ini dibentuk khusus untuk bapak-bapak. Adapun awalnya bimbingan tersebut ditempatkan di rumah warga yaitu Haji Umar. Namun, beberapa bulan kemudian bimbingan tersebut tidak lagi berjalan. Karena Ustaz Muda sering diundang keluar desa untuk memberikan ceramah. Sehingga majelis tersebut terpaksa harus ditutup. Setelah itu dibentuk lagi di rumah bapak $\mathrm{H}$. Roni, namun tempat itu ditutup juga, disebabkan hal yang sama. Kemudian sekarang dibentuk lagi, tepatnya di rumah Bapak Sudirman yang merupakan anak dari Haji Roni. Tidak hanya itu, melihat semangat bapak-bapak yang ingin belajar, maka dibentuk lagi majelis tersebut dan ditempatkan di Masjid Baitul Izzah Desa Kayu Besi, sampai sekarang.

3) Majelis ibu-ibu

Majelis ini terbentuk pada tahun 2009. Hal itu disebabkan permintaan dari Ustazah Syarifah yang merupakan orang Desa Kayu Besi, sehingga majelis untuk ibu-ibu pun dibentuk dan bertempat di Pondok Pesantren Riyaadhul Jannah sampai sekarang. Majelis ini diperuntukan bagi ibu-ibu yang sudah berkeluarga. Adapun perbedaannya dengan majelis Riyaadhul Jannah, terletak pada waktu pelaksanaannya, jemaahnya, dan materi bimbingan. Dalam majelis ini, Ustaz Muda memberikan materi terkait permasalahan kewanitaan, seperti cara salatnya perempuan, wudunya, dan tata cara hidup, baik berkeluarga, bertetangga, dan bermasyarakat dalam pandangan Islam.

4) Majelis Kutubus Salaf Bangka Belitung

Majelis ini dibentuk untuk mensiasati berkembangnya para penceramah yang keilmuannya dianggap liberal. Oleh sebab itu, dia mengajak masyarakat untuk membangun majelis tersebut dengan menggandeng Habib Umar bin Alwi Assegaf yang merupakan gurunya. Alhasil, majelis tersebut dibangun pada tahun 2011 di Desa Puding Besar, Kabupaten Bangka. Majelis tersebut diberi nama Majelis Kutubus Salaf, yang hanya mengajarkan keilmuan Islam yang berdasarkan kitab-kitab klasik. Majelis tersebut masih berjalan sampai sekarang.

5) Majelis Pecinta Islam (MPI) Bangka Belitung 
Majelis ini dibentuk atas saran dari Habib Muhammad Rizieq bin Husein Syihab dan Habib Umar bin Alwi Assegaf, pada tahun 2012. Mendengar saran tersebut maka dibentuklah majelis taklim itu dan diberi nama Majelis Pecinta Islam (MPI). Majelis tersebut masih berjalan sampai sekarang dan diketuai oleh Ustaz Muda.

6) Majelis Daarul Hijroh

Majelis ini dibentuk dikarenakan Ustaz Muda melihat semangat para remaja putri Desa Kayu Besi untuk mempelajari ilmu agama. Melihat hal tersebut maka Ustaz Muda membentuk majelis taklim khusus para remaja yang diberi nama Daarul Hijroh pada tahun 2020. Majelis tersebut masih berjalan sampai sekarang.

\section{b. Kegiatan}

Setelah pembentukan dilakukan, Ustaz Muda melaksanakan kegiatan bimbingan dengan memberikan materi-materi keislaman yang dianggap perlu diajarkan dan sangat penting untuk dipahami oleh masyarakat Desa Kayu Besi. Dalam pengamatan penulis terhadap kegiatan bimbingan Ustaz Muda diketahui bahwa sebelum kegiatan dimulai para anggota bimbingan membaca maulid Simthud Durar. Setelah itu Ustaz Muda mulai memberikan materi pembinaan tauhid, fikih, dan akhlak. Ustaz Muda mengajak anggota bimbingan untuk kembali ke jalan Allah SWT, atas perbuatan-perbuatan dosa yang dimiliki dan mengajak agar masyarakat memahami ajaran Islam secara baik dan benar, sesuai dengan apa yang tertera dan dibawa pada kitab-kitab para salafus sholih. Setelah materi disampaikan Ustaz Muda, maka ditutup dengan doa penutup majelis. Demikian itu menandakan bahwa kegiatan pemberian bimbingan sudah selesai. Ketika kegiatan selesai, maka masyarakat pun bersiapsiap untuk kembali ke rumah masing-masing.

Menurut hemat penulis, materi yang disampaikan oleh Ustaz Muda merupakan arahan, bimbingan, dan petunjuk yang diberikan kepada masyarakat. Demikian itu sedikit banyaknya memberikan pengaruh guna upaya pemberdayaan masyarakat dalam menumbuhkembangkan kecerdasan jasmaniah dan rohaniah mereka. Ustaz Muda berharap dengan materi yang disampaikan dapat dipahami dan diteladani masyarakat dalam kehidupan sehari-hari secara konsisten. Materi yang diberikan Ustaz Muda kepada masyarakat yaitu tata cara hidup bermasyarakat menurut Islam, cara mendidik anak, menghormati orang tua, hidup berkeluarga, dan masalah ibadah, seperti salat, zakat, dan puasa. Dalam kegiatan tersebut, masyarakat memandang dan menempatkan Ustaz Muda sebagai sumber ilmu pengetahuan agama Islam.

Ustaz Muda menyatakan bahwa upaya sungguh-sungguh dalam meningkatkan kualitas sumber daya manusia (SDM), salah satunya melalui kegiatan bimbingan yang dilaksanakan. Karena kegiatan itu dapat menata dan meningkatkan kehidupan masyarakat. Terlebih kegiatan bimbingan tersebut ternyata mendapatakan penghargaan dari masyarakat dan akhirnya menjadikan posisi Ustaz Muda semakin dikenal sebagai tokoh agama dalam kehidupan beragama. Demikian itu terbukti dari sikap masyarakat dan perlakuan masyarakat yang merasa bangga dengan kehadirannya di tengah-tengah mereka. Oleh sebab itu, mereka sangat menyayangi dan menghormatinya dan selalu siap berbuat terbaik demi kepentingan Ustaz Muda dan keluarga, serta kepentingan kegiatan bimbingan Islam yang dijalani.

Dalam kesempatan wawancara penulis dengan beberapa anggota masyarakat di Desa Kayu Besi, diperoleh penjelasan bahwa mereka menganggap Ustaz Muda dan kegiatan bimbingan yang dilaksanakannya adalah bagian dari kehidupan mereka yang tidak terpisahkan. Sikap dan perlakuan Ustaz Muda terhadap masyarakat telah mengikat hati mereka untuk memperlihatkan kepedulian dan rasa saling memiliki yang besar terhadap kegiatan bimbingannya. Dengan demikian, semakin jelas bahwa upaya Ustaz Muda menata 
kehidupan masyarakat, terlebih anggota yang mengikuti bimbingannya untuk menjadi bagian penting memperkuat posisinya di masyarakat sebagai tokoh agama dalam aspek keagamaan.

Dalam menyampaikan materi, komunikasi yang terjadi pada kegiatan bimbingan Ustaz Muda adalah komunikasi satu arah. di mana, komunikasi tersebut berfokus pada keaktifan dari Ustaz Muda dalam menjelaskan materi bimbingan. Anggota bimbingan Ustaz Muda dapat dikatakan kurang aktif bahkan tidak aktif.

\section{Unsur-unsur dalam bimbingan}

Setiap kegiatan bimbingan pastinya terdapat unsur-unsur di dalamnya. Sebab itulah kegiatan bimbingan bisa terlaksana dengan optimal. Begitu juga dalam kegiatan bimbingan Ustaz Muda. Adapun unsur-unsur tersebut, yaitu: dinamika, pembimbing, dan anggota bimbingan.

a. Dinamika bimbingan

Setelah penulis melakukan penelusuran, didapati penjelasan bahwa kegiatan yang dibimbing oleh Ustaz Muda sekadar pemberian pemahaman keagamaan. Ketika materi sudah selesai disuguhkan, maka langsung pembacaan doa. Sehingga hal itu terlihat bahwa tidak adanya pertanyaan yang didiskusikan. Ustaz Muda menjelaskan bahwa kegiatan yang diberikannya sebagai upaya memberikan pemahaman tentang ajaran Islam kepada anggota bimbingan. Setelah materi disampaikan maka dirinya langsung membaca doa.

Anggota bimbingan menegaskan bahwa mereka pergi ke tempat bimbingan untuk mendengarkan penjelasan dari Ustaz Muda. Mereka memang jarang bahkan tidak pernah bertanya kepada Ustaz Muda, karena dianggap sudah cukup mengerti. Terlebih cara Ustaz Muda menjelaskannya dengan tegas dan tuntas. Sehingga untuk bertanya lebih dalam tidak diperlukan.

b. Pembimbing

Dalam memberikan bimbingan, seorang pembimbing memiliki peran penting dalam kelancaran kegiatan tersebut. Pembimbing harus memiliki kompetensi di bidangnya. Ustaz Muda merupakan orang yang memiliki kecerdasan dalam bidang ilmu agama. Hal itu pun diakui oleh masyarakat bahwa Ustaz Muda adalah orang yang alim dalam ilmu agama. Kedalaman ilmunya didapatkan dari pendidikan yang merupakan alumni Pondok Pesantren Syaikhona Cholil Bangkalan, Madura. Sehingga masyarakat mempercayai dirinya dapat memberikan pemahaman tentang Islam kepada mereka.

Para anggota bimbingan menilai Ustaz Muda memiliki ilmu tinggi, kearifan luas, dan kesalehan. Hal itu dirasakan selama bertahun-tahun hidup bersama dalam berbagai kegiatan, baik kegiatan pengajaran maupun sosial. Oleh karenanya, hal itu dapat dimaklumi jika pada akhirnya mereka memandang Ustaz Muda sebagai pribadi yang alim. Secara nyata dirasakan oleh mereka bahwa pribadi yang alim pada Ustaz Muda tercermin dari sikap optimisnya dalam menjalankan kegiatan bimbingan Islam. Dengan demikian, beralasan pula jika Ustaz Muda dipandang oleh anggota bimbingan untuk dijadikan teladan terbaik dalam memberikan bimbingan kepada mereka.

c. Anggota bimbingan

Kegiatan bimbingan terlaksana juga adanya peran penting dari anggota bimbingan. Sebab kehadiran anggota bimbingan sangat diharapkan, sebagai orang yang akan diberikan bimbingan. Adapun kegiatan yang dilaksanakan oleh Ustaz Muda terlihat tidak aktif. Sejatinya dalam kegiatan bimbingan, anggota harus aktif dalam mendengarkan bimbingan dan bertanya terkait materi yang disampaikan. Namun setelah penulis menelaah ke 
lapangan, maka didapati penjelasan bahwa anggota bimbingan tidak merespons dengan aktif terkait materi yang disampaikan.

Setelah penulis meminta penjelasan dari anggota bimbingan maka dipahami bahwa mereka bingung harus bertanya apa, karena menurut mereka materi yang disampaikan oleh Ustaz Muda sudah cukup jelas. Terlebih mereka sangat mempercayai Ustaz Muda dapat membimbing mereka ke jalan yang lebih baik lagi. Dalam kegiatan bimbingan tersebut, mereka datang ingin mendengarkan materi bimbingan dan memahami ajaran Islam secara baik dan benar sesuai dengan ajaran yang dibawa oleh Nabi Muhammad SAW.

\section{Kontestasi Guru Tua dan Ustadz Muda}

\section{A. Potret Hubungan Guru Tua dan Ustaz Muda di Bangka Belitung}

Guru Tua dan Ustaz Muda merupakan tokoh agama yang dipercayai oleh masyarakat untuk memberikan bimbingan Islam kepada mereka. Hubungan antara kedua tokoh agama tersebut sangat erat. Keeratan hubungan mereka terbukti ketika dalam menjalankan kegiatan keagamaan di masyarakat. Mereka kerap kali terlihat bersama dalam satu kegiatan keagamaan, seperti tahlilan, maulidan, dan acara keagamaan lainnya.

Pertemuan keduanya berawal pada tahun 2007. Di mana Ustaz Muda datang dari Bangkalan Madura untuk menjalankan tugas pengabdian dari Pondok Pesantren Syaikhona Cholil Bangkalan, Madura. Awalnya Ustaz Muda ditempatkan di Desa Kimak, Kecamatan Pemali, Kabupaten Bangka, akan tetapi hal itu hanya berjalan dalam kurun waktu tiga bulan. Demikian itu disebabkan ketidakbetahan Ustaz Muda tinggal di desa tersebut. Ketika Ustaz Muda ingin pulang ke Madura, maka ia pun diminta untuk tinggal di Desa Kayu Besi, Kecamatan Puding Besar, Kabupaten Bangka. Demikian itu dilakukan untuk membantu membimbing masyarakat di desa tersebut.

Guru Tua mengenalkan Ustaz Muda kepada masyarakat bahwa Ustaz Muda adalah seorang ustaz alumni Pondok Pesantren Syaikhona Cholil Bangkalan, Madura. Oleh sebab itu, Guru Tua meminta kepada masyarakat untuk dapat menerimanya dan meminta bimbingan keagamaan kepadanya. Permintaan Guru Tua tersebut pun disambut oleh masyarakat dengan senang hati. Hal itu mengingat sosok Guru Tua adalah orang yang sangat disegani masyarakat desa tersebut.

Setelah penulis melakukan wawancara kepada masyarakat, maka didapati penjelasan bahwa hubungan antara Guru Tua dan Ustaz Muda sangat akrab. Mereka terlihat selalu bersama dalam setiap kegiatan keagamaan dan sosial kemasyarakatan. Sebagai masyarakat, tentunya mereka sangat senang sekali dengan kehadiran Ustaz Muda di desanya. ${ }^{95}$ Oleh sebab itu, kehadiran Ustaz Muda dimanfaatkan untuk belajar agama oleh masyarakat.

Hubungan antara Guru Tua dan Ustaz Muda terjalin akrab. Mereka bersama-sama bersinergi dalam membimbing masyarakat. Masyarakat mengatakan bahwa desa mereka sangat terbantu dengan kehadiran Guru Tua dan Ustaz Muda. Hal itu disebabkan, sebagai manusia biasa masyarakat juga ingin mendapatkan bimbingan dalam memahami ajaran Islam dan berkehidupan yang aman dan damai. Setelah penulis melakukan penelusuran lebih lanjut, didapatkan penjelasan bahwa masyarakat sangat menghormati Guru Tua dan Ustaz Muda. Mereka sangat berantusias mengikuti kegiatan bimbingan Islam yang dilaksanakan keduanya. Masyarakat sangat terbantu dalam proses memahami ajaran Islam. ${ }^{96}$

95 Wawancara kepada masyarakat, 12 Januari 2020.

96 Observasi pada tanggal 15 - 21 Desember 2019. 
Guru Tua dan Ustaz Muda selalu terlihat bersama dalam suatu kegiatan keagamaan dan sosial, seperti mauludan, tahlilan, tasyakuran, gotong royong, dan lainnya. Hubungan keduanya terjalin harmonis. Dengan demikian, masyarakat Desa Kayu Besi pun merasakan ketenangan dan kedamaian. Namun tidak dapat disangkal, ternyata hubungan tersebut berjalan tidak lama. Guru Tua dan Ustaz Muda pun sudah tidak terlihat bersama lagi dalam suatu kegiatan. Masyarakat pun timbul tanya terkait keadaan yang terjadi di antara mereka. Dari hubungan yang kurang baik tersebut, akhirnya masyarakat kebingungan harus mengikuti siapa. Sehingga hal itu cukup membuat kondisi masyarakat yang awalnya tenang berubah menjadi tidak tenang. Terlebih terjadinya perbedaan pendapat antara Guru Tua dan Ustaz Muda dalam urusan agama.

Penulis mencoba mencari tahu terkait perihal awalnya terjadinya ketidakharmonisan hubungan keduanya. Sehingga penulis menemukan benang merahnya yaitu awal dari perbedaan pendapat tersebut adalah keputusan Ustaz Muda untuk memilih bergabung pada organisasi Front Pembela Islam (FPI) pada tahun 2012. Guru Tua sudah mencoba memberikan nasihat kepada Ustaz Muda agar tidak bergabung dengan organisasi tersebut, namun nasihat Guru Tua tidak digubris oleh Ustaz Muda. Oleh sebab itu, Guru Tua menerima keputusan yang diambil oleh Ustaz Muda dan memilih untuk menghindari hal tersebut. Gabungnya Ustaz Muda ke organisasi FPI awalnya tidak membuat hubungan antara mereka bubar. Mereka terlihat saling tegur sapa menjalin keakraban walaupun berbeda pandangan. Akan tetapi, jalinan tersebut pun ternyata harus bubar, karena pertarungan dan perdebatan tidak dapat dihindarkan. Sehingga hal itu, membuat Guru Tua memilih lebih baik menghindar. 97

Dari pembahasan tersebut, dapat dipahami bahwa kehadiran Ustaz Muda ke Desa Kayu Besi, awalnya atas permintaan dari Guru Tua. Masyarakat pun menerimanya dengan sepenuh hati. Hubungan antara keduanya pun terjalin harmonis dan selalu dijadikan masyarakat sebagai tempat untuk mempelajari ilmu agama. Masyarakat merasakan ketenangan dan penuh kegembiraan, karena mereka sangat terbantu dalam memahami ajaran Islam. Namun hal tersebut berjalan dalam kurun waktu beberapa tahun saja, karena diketahui bahwa hubungan antara keduanya ternyata tidak harmonis lagi. Hal tersebut disebabkan perbedaan pandangan dan bersikap keberagamaan antara keduanya.

\section{Kontestasi kealiman: simbol dan problem identitas}

Kedudukan seorang tokoh agama dalam masyarakat sangat diagungkan, terlebih bagi masyarakat awam di pedesaan. Dalam beberapa hal, tokoh agama menunjukkan kekhususannya dalam bentuk berpakaian yang merupakan simbol kealiman yaitu kopiah dan surban. ${ }^{98}$ Tokoh agama merupakan figur yang dapat diteladani dan dapat memberikan bimbingan. Masyarakat meyakini dan mempercayai tokoh agama itu sendiri. Keyakinan mereka memiliki pelbagai macam bentuknya. Ada masyarakat yang hanya sekadar memiliki keyakinan bahwa tokoh agama dapat dijadikan sebagai tempat bertanya dan berdiskusi tentang agama, serta dianggap sebagai orang yang mampu dalam mengatasi permasalahan dan mengambil keputusan dalam hidupnya. ${ }^{99}$ Begitu juga halnya, pengakuan masyarakat Desa Kayu Besi terhadap ketokohan Guru Tua dan Ustaz Muda.

Setelah penulis melakukan penelusuran, didapati penjelasan bahwa Guru Tua merupakan sosok orang yang sangat dihormati dan disegani oleh masyarakat Desa Kayu Besi.

\footnotetext{
${ }^{97}$ Observasi pada tanggal 12 Desember 2019.

${ }^{98}$ Zamakhsyari Dhofier, Tradisi Pesantren: Studi Tentang Pandangan Hidup Kyai (Jakarta: LP3ES, 1982), 56.

${ }^{99}$ Weny Ekaswati, Kepercayaan Masyarakat Terhadap Kyai (Yogyakarta: Fakultas Psikologi Universitas Islam Indonesia, 2006), 7.
} 
Penghormatan diberikan karena masyarakat menganggap Guru Tua tidak hanya dapat memberikan bimbingan Islam, akan tetapi juga dapat menjadi tempat mereka meminta solusi atas permasalahan yang dihadapi dalam kehidupan. Cara berpakaian Guru Tua dapat dibilang sederhana. Kesederhanaan tersebut terlihat karena pakaiannya tidak jauh berbeda dengan masyarakat pada umumnya yang tinggal di desa. Pakaian yang digunakan adalah baju kemeja berkerah, kain sarung, dan peci hitam. Sedangkan Ustaz Muda merupakan sosok orang yang dihormati karena dia dianggap masyarakat memiliki pengetahuan agama. Berbeda halnya dengan Guru Tua, cara berpakaian Ustaz Muda tidak sama seperti masyarakat biasanya atau dapat dikatakan seperti apa yang digunakan oleh orang Arab. Pakaiannya yaitu kain sarung, peci putih, surban, dan jubah. ${ }^{100}$

Menurut Guru Tua, dalam berpakaian dia tidak mau dibikin ribet. Bagi dirinya pakaian tersebut yang penting bersih, suci, dan sopan. Alim tidaknya seseorang tidak dapat dinilai dari pakaiannya. Terkadang ada yang berpakaian compang-camping, tetapi memiliki pengetahuan yang luas dalam bidang agama. Oleh sebab itu, jangan mengadili seseorang dari cara berpakaiannya. Masyarakat mengatakan bahwa penghormatan diberikan kepada Guru Tua dikarenakan dirinya memiliki pemahaman agama. Penampilannya yang sederhana sudah menjadi ciri khasnya. Masyarakat meyakini bahwa Guru Tua adalah orang yang dapat membimbing mereka dan dapat memberikan solusi terhadap permasalahan yang dihadapi dalam kehidupan. Oleh sebab itu, masyarakat tidak mempermasalahkan gaya berpakaian Guru Tua yang sederhana. ${ }^{101}$

Berbeda halnya Guru Tua, Ustaz Muda berpendapat bahwa pakaian yang digunakannya adalah pakaian disunahkan Nabi Muhammad SAW. Kesunahan tersebut dikarenakan dirinya beranggapan bahwa apapun yang digunakan oleh Nabi Muhammad SAW, maka perlu diteladani. Terlebih pakaian yang digunakannya merupakan simbol umat Islam. Dengan demikian, sebagai umat Islam harus berbangga menggunakannya. Oleh sebab itu, jika ada orang yang menentang pakaian tersebut, maka mereka telah menentang ajaran Nabi Muhammad SAW.

Kontestasi Guru Tua dan Ustaz Muda untuk memperebutkan legitimasi masyarakat atas kealiman yang mereka miliki dilakukan secara nyata. Dalam hal ini ada sebuah kejadian, seorang masyarakat bertanya kepada Guru Tua terkait pakaian jubah. Kemudian Guru Tua menjawab bahwa dalam beribadah kepada Allah SWT, pakaian yang digunakan yang penting rapi, sopan, menutup aurat, dan suci. Oleh sebab itu, walaupun menggunakan jubah jika tidak suci maka hal tersebut juga tidak diperbolehkan dalam melaksanakan ibadah.

Pernyataan Guru Tua tersebut, terdengar ke telinga Ustaz Muda. Alhasil, perbedaan pendapat itu muncul. Ustaz Muda bersikeras bahwa pakaian jubah adalah pakaian terbaik dan sunah Nabi Muhammad SAW. Oleh sebab itu, Ustaz Muda beranggapan bahwa siapa pun orang yang tidak menerima hal itu maka dirinya telah menolak sunah Nabi Muhammad SAW. Kemudian Ustaz Muda menegaskan bahwa bagi siapa saja yang belum puas atas argumentasinya, maka dia mengundang masyarakat untuk datang ke kediamannya. Bila perlu dirinya mengajak berdebat orang yang tidak menerima pakaian yang disunahkan oleh Nabi Muhammad SAW., dan menunjukkan siapa di antara mereka yang paham atas ajaran agama Islam. Tidak sampai di situ, setiap kali Ustaz Muda menjadi khotib pada hari Jumat. Dia membawa materi terkait pakaian yang disunahkan oleh Nabi Muhammad SAW, yaitu jubah.

100 Observasi, 02 - 12 Januari 2020.

101 Observasi tertanggal $02-12$ Januari 2020. 
Khotbah Ustaz Muda menekankan saat-saat tertentu di kehidupan Nabi Muhammad SAW. Misalnya, ketika dia berbicara tentang cara berpakaian Nabi Muhammad SAW, Ustaz Muda mendesak umat Islam untuk meneladani dan belajar dari pemahaman yang lebih dekat tentang Nabi Muhammad SAW, sebagai figur yang musti diikuti. Oleh sebab itu, sebagai figur yang musti diteladani, maka sudah menjadi kewajiban bagi pengikutnya untuk mencontoh akhlak dan cara berpakaian Nabi SAW.

Tantangan Ustaz Muda untuk mengajak debat siapa pun orang yang menentang pakaian jubah terdengar oleh Guru Tua yang ketika itu memberikan bimbingan Islam kepada masyarakat. Guru Tua meminta maaf dan mengklarifikasi terkait pendapatnya tentang pakaian jubah. Dalam penjelasannya, dirinya tidak pernah mempermasalahkan pakaian seseorang. Hal itu yang terpenting dipikirkan adalah kesopanan, kerapian, dan kebersihan pakaian yang hendak digunakan. Oleh sebab itu, jika ada orang yang menganggap pakaian jubah adalah sunah dan pakaian yang terbaik dipersilahkan. Meskipun demikian, jika orang tidak ingin menggunakannya juga jangan dipermasalahkan dan diperdebatkan. Hal itu dikarenakan, setiap orang bebas mengekspresikan keberagamaannya dalam kehidupan.

Selain dari kontestasi kealiman terkait simbol, maka ada juga problem identitas. Dalam hal ini, Guru Tua tidak pernah menunjukkan identitasnya pada masyarakat. Menurutnya, pemberitahuan identitas dirinya tidak sangat dipentingkan oleh masyarakat. Akan tetapi, hal terpenting adalah bermanfaat bagi kemaslahatan masyarakat dalam aspek kehidupan. Setelah penulis melakukan penelusuran dan mewawancarai masyarakat, didapati penjelasan bahwa mereka tidak mengetahui identitas pendidikan Guru Tua. Mereka bersumsi bahwa hal itu tidak terlalu penting untuk dipikirkan. Meskipun demikian, mereka meyakini bahwa Guru Tua merupakan orang yang memiliki pengetahuan agama yang luas.

Menurut Ustaz Muda, identitas seorang tokoh agama yang memberikan pengajaran Islam kepada masyarakat sangat penting diberitahukan. Karena masyarakat juga harus mengetahui apa, di mana, kepada siapa, dan kapan, tokoh agama mempelajari ilmu agama. Sehingga demikian itu akan menjadi nilai jual bagi tokoh agama tersebut. Oleh sebab itu, dalam setiap kegiatan bimbingan, baik berupa pengajian dan ceramah agama, maka Ustaz Muda terlebih memperkenalkan dirinya kepada para jemaah. Hal itu dilakukannya agar masyarakat tidak meragukan kealimannya.

Dalam beberapa kegiatan bimbingan Islam Guru Tua, terlihat sambutan masyarakat biasa saja. Guru Tua berpendapat bahwa dirinya tidak ingin dihormati. Ketika dalam suatu acara keagamaan, petugas membawa acara pun mengenalkan dirinya dengan biasa saja, tanpa menyebutkan identitas pendidikan dan keilmuannya. Hal itu tampak sekali perbedaannya dengan sambutan yang diberikan kepada Ustaz Muda. Di mana sambutan yang diberikan oleh pembawa acara sangat istimewa yaitu dengan cara menyebutkan kota kelahiran dan identitas pendidikannya.

\section{Kontestasi kuasa: otoritas karismatik dan otoritas legal}

Para tokoh agama dalam masyarakat terkadang diakui sebagai pemimpin karismatik. Mereka memiliki kemampuan untuk memengaruhi orang dengan kelebihan tertentu. Seorang tokoh agama dapat dikatakan karismatik adalah mereka yang memiliki kekuatan luar biasa atau dikenal sebagai otoritas karismatik. Menurut para pengikutnya, tokoh agama semacam itu adalah harapan untuk menuju kehidupan yang lebih baik. Hal tersebut dikarenakan tokoh agama dianggap sebagai pelindung dan penyelamat. Para tokoh agama membangun dan mempertahankan keberadaan dan pengaruh mereka di masyarakat, seperti upaya mereka membangun kekuatan melalui hubungan sosial. 
Istilah karisma juga menunjukkan pada kualitas pribadi, sehingga hal itu dapat dibedakan dengan banyak orang. Bahkan tokoh agama dianggap dan diyakini memiliki kekuatan spiritual, sehingga keberadaan mereka mendapat dukungan banyak orang. Meskipun demikian, ada juga keberadaan tokoh agama yang kurang dianggap banyak orang. Sehingga hal itu menjadikan dirinya untuk mencari dan membangun otoritasnya sendiri.

Menurut Max Weber, setidaknya ada tiga perspektif terkait fenomena kepemimpinan. ${ }^{102}$ Pertama, kepemimpinan dapat dianggap sebagai kemampuan dalam diri seseorang. Demikian itu menandakan bahwa seseorang tersebut memiliki daya tarik sendiri, sehingga dapat menyebabkan orang lain menerima kehendaknya sebagai sesuatu yang harus diteladani. Hal itu dikarenakan dirinya memiliki sifat yang supernatural dan dapat memperoleh massa yang banyak dari masyarakat. Kepemimpinan yang mendapatkan kekuatan dari orang banyak disebut otoritas karismatik (charismatic authority). Kedua, kepemimpinan tidak berkonsentrasi pada kekuatan individu, sehingga otoritasnya dibentuk dari posisi atau status yang dipegangnya. Kepemimpinan seperti ini dikenal dengan otoritas legal (legal authority). Kekuatan dan haknya dalam memimpin harus mematuhi prosedur organisasi yang dipegangnya. Ketiga, keyakinan terhadap waktu dan kebiasaan yang dapat dimiliki oleh individu atau kelompok. Individu atau kelompok yang memiliki otoritas ini dihormati karena mereka mempunyai kekuasaan dan otoritas yang telah melembaga dan bahkan menjiwai masyarakat. Kepemimpinan tersebut dikenal dengan istilah otoritas tradisional (traditional authority).

Setelah penulis melakukan penelusuran dan wawancara terhadap berbagai kalangan, ada beberapa sifat yang menonjol pada diri Guru Tua. Pertama, sabar dan tidak pernah marah. Penulis melakukan wawancara ke beberapa masyarakat, mereka menyatakan bahwa sifat yang menonjol pada diri Guru Tua adalah sifat sabar yang sangat kuat dan tidak pernah marah. Dalam kondisi bagaimana pun Guru Tua selalu mampu mengendalikan dirinya, sehingga kemarahannya tidak pernah tampak. Seandainya pun dia marah, tetapi hanya ditampakkan dengan bahasa isyarat, misalnya dia menggertak. Bahkan, ketika dirinya difitnah dan sejumlah jemaahnya ingin mengambil tindakan terhadap mereka yang menyebarkan fitnah, Guru Tua berusaha meredakan amarah para jemaah seraya mendoakan agar yang memfinah menjadi orang yang baik. Kedua, bersahaja. Dari aspek fisiknya dapat terlihat bahwa rumah dan transportasinya melambangkan kesederhanaan hidup. Dalam kehidupan sehari-hari, Guru Tua pun dikenal bersahaja. Ketiga, tawaduk, yaitu sifat yang selalu rendah hati, tidak pernah menunjukkan bahwa dia adalah orang yang berilmu, selalu merendahkan diri di hadapan orang-orang. Selain dari beberapa sifat tersebut, Guru Tua dikenal sangat menghormati dan patuh pada orang tuanya, serta dirinya membuka ruang kritik dan saran bagi siapa pun yang menemui kesalahannya.

Sebagaimana telah disinggungkan di atas, bahwa Max Weber menyatakan charismatic authority salah satunya bersifat supernatural. Meskipun demikian, setelah melihat otoritas karismatik yang dimiliki Guru Tua maka diketahui bahwa sifatnya lebih alamiah (nature). Kemungkinan dari segi genealogi saja yang cenderung supernatural. Namun dari segi penguasaan ilmu, pendidikan, dan kualitas kepribadian yang kuat, jelas menunjukkan sifat alamiah.

Ketika penulis melakukan penelusuran dan wawancara ke berbagai kalangan, maka didapati penjelasan bahwa pada awal Ustaz Muda datang ke Desa Kayu Besi, ada beberapa sifat yang ditonjolkan. Pertama, ramah, yaitu dia baik hati, menarik budi bahasa dan

102 M. Weber, The Theory of Social and Economic Organization, Transleted by Talcott Parson (New York: The Fress Press, 1966), 358. 
sikapnya, dan suka bergaul kepada masyarakat. Kedua, sederhana. Kesederhanaan tersebut terlihat dari keadaan rumahnya dan kendaraannya yang juga melambangkan kesederhanaan hidup. Dari sifatnya seperti itu, dia mulai dilirik masyarakat dan dihormati, terlebih dirinya diketahui merupakan alumni pondok pesantren. Sehingga masyarakat menganggap dirinya memiliki keluasan ilmu pengetahuan tentang agama. Berangkat dari kepercayaan masyarakat tersebut, Ustaz Muda pun akhirnya membangun majelis taklim, yang dinamainya Majelis Taklim Riyaadhul Jannah. Setelah beberapa tahun kemudian, majelis taklim tersebut berubah nama menjadi Pondok Pesantren Riyaadhul Jannah. Hal itu seiring membuat nama Ustaz Muda mulai banyak dikenal. Banyak masyarakat yang belajar agama dan menyekolahkan anak-anak mereka di pondok tersebut. Dia pun mulai dipercaya masyarakat untuk memberikan bimbingan Islam kepada masyarakat.

Setelah beberapa tahun kemudian, tepatnya pada tahun 2011. Nama Ustaz Muda pun mulai bergaung di Bangka Belitung. Dengan demikian, dirinya mulai disibukkan dengan kegiatan pemberian bimbingan keagamaan di luar. Hal itu menyebabkan pondok pesantren yang dibangun mulai tidak terurus. Ustaz Muda pun mendirikan Majelis Pecinta Islam (MPI) dan Majelis Kutubus Salaf (MKS) yang bertempat di Desa Puding Besar. Dari sejak itu, Ustaz Muda sudah mulai kehilangan sifat yang dulu dimiliki. Masyarakat pun mulai meninggalkan kegiatan bimbingannya, karena mereka merasakan perbedaan pada Ustaz Muda yang dulu mereka kenal. Nama Ustaz Muda pun semakin dikenal, terlebih dirinya menggandeng beberapa habib yang masyhur di kalangan masyarakat yang berpaham Ahlus Sunnah wal Jama'ah.

Habib-habib tersebut seperti, Habib Umar bin Alwi Assegaf dari Palembang, Habib Rizieq bin Husein Syihab, Habib Hanif Al-Athos, dan lain sebagainya. Dengan menggandeng para habib tersebut, nama Ustaz Muda pun semakin bergaung. Sehingga pada akhirnya pada tahun 2012, dirinya bergabung dengan Front Pembela Islam (FPI) dan diangkat sebagai Ketua Umum Dewan Pimpinan Pusat (DPP) Bangka Belitung. Oleh sebab itu, otoritas Ustaz Muda pun terbangun dari beberapa organisasi yang dia geluti, khususnya FPI. Bergabungnya Ustaz Muda ke dalam beberapa organisasi tersebut, sifat yang mulai ditonjolkan adalah mudah marah dan merasa paling benar.

Ada sebuah kejadian di mana pada tahun 2015, Ustaz Muda pernah mengajak debat Ustaz Masyhuri yang merupakan alumni dari Universitas al-Azhar Kairo, Mesir, dan dosen di IAIN SAS Bangka Belitung. Hal itu berawal dari perbedaan pendapat antara jemaahnya Ustaz Muda yang berada di Puding Besar dengan Ustaz Masyhuri. Kejadian itu, ketika Ustaz Masyhuri menjadi khotib pada hari Jumat, kemudian menyampaikan permasalahan yang dianggap bertentangan dengan mereka. Kabar itu pun disampaikan kepada Ustaz Muda. Spontanitas Ustaz Muda menantang untuk berdebat dengan Ustaz Masyhuri di Gedung Serba Guna (GSG) di Desa Puding Besar.

Ustaz Muda mengajak rombongannya yaitu jemaahnya yang tergabung di FPI dan MPI, untuk berangkat ke Desa Puding Besar dengan membawa kitab-kitab yang diletakkan di mobil. Namun, perdebatan itu tidak didatangi oleh Ustaz Masyhuri. Sebab, Ustaz Masyhuri pergi menemui Guru Tua di Desa Kayu Besi untuk meminta nasihat dari Guru Tua. Kemudian Guru Tua mengatakan, "sudahlah jangan diladeni. Biarkanlah masyarakat yang menilai. Perdebatan tidak akan menyelesaikan masalah. Apalagi perdebatan dengan suasana yang amarah. Pasti ujung-ujungnya jadi masalah". Ustaz Masyhuri pun pulang dan tidak menggubris ajakan Ustaz Muda. Alhasil, Ustaz Muda dan rombongan pulang. Dari kejadian tersebut, Ustaz Muda mengkhotbahkan kepada masyarakat bahwa Ustaz Masyhuri takut dikalahkan olehnya dan dengan bangganya menyampaikan kepada masyarakat bahwa dirinya pernah mengajak dosen IAIN SAS Bangka Belitung namun dosen tersebut kalah. 
Tidak hanya itu, kejadian yang lain diketahui bahwa seorang khotib naik mimbar. dia adalah anak muda yang dipercayai memberikan khotbah oleh ketua masjid. Awalnya pemuda tersebut bertugas sebagai Ma'asyir (orang yang bertugas sebelum khotib naik mimbar), namun tampak ketua masjid menyuruh pemuda tersebut menjadi khotib untuk menggantikan khotib yang tidak datang. Suasananya mati listrik. Selesai sang pemuda tersebut memberikan khotbah, maka lagi-lagi Ustaz Muda mengatakan tidak sah. dirinya mengajak masyarakat dan jemaah masjid untuk menggantikan dengan salat Zuhur. Akan tetapi tidak satu pun dari jemaah salat Jumat, bahkan jemaah bimbingan Ustaz Muda mengikuti kemauannya. Kemudian terlihat sang pemuda tersebut meminta pendapat Guru Tua yang pada hari itu bertugas menjadi imam. Kemudian dengan santun Guru Tua mengatakan, "sudah diam saja. Insya Allah sah". Alhasil, pada hari itu hanya Ustaz Muda sendiri yang melaksanakan salat Zuhur.

Selain dari pada itu, perlu diketahui bahwa ketokohan Guru Tua memang tidak bisa diragukan lagi. Hal itu terbukti ketika ada kasus praktik perdukunan atau dukun cabul di Desa Kayu Besi, yang sempat menggegerkan masyarakat se-Bangka Belitung. Pada malam itu, rumah sang dukun dikepung oleh masyarakat yang emosi atas kelakuannya. Sementara pihak kepolisian pun sudah tidak kuasa lagi menahan amarah masyarakat. Sehingga hal itu membuat rumah sang dukun dihancurkan masyarakat. Melihat kondisi tersebut, pihak kepolisian pun meminta bantuan Guru Tua. Tidak beberapa lama kemudian, Guru Tua datang dan membuat para masyarakat terdiam dan tak berkutik. Kemudian Guru Tua menyatakan dengan suara lantang, "Jangan kalian main hakim sendiri, kita hidup di negara hukum. Jangan merusak benda mati. Rumahnya tidak bermasalah. Siapa yang berani menghancurkan rumahnya, maka ke sini berhadapan dengan saya. Kalau memang merasa nyalinya sudah besar". Dari gertakan Guru Tua, masyarakat pun sepi seribu bahasa. Dukun pun bersama keluarga diamankan polisi untuk diproses secara lebih lanjut.

Perlu dipahami bahwa kekaguman masyarakat atas kepribadian seorang tokoh agama yang dianggap mumpuni dalam mengatasi konflik di masyarakat adalah faktor utama seorang tokoh agama mendapatkan karisma dari masyarakatnya. Kemampuan tersebut menunjukkan bahwa tokoh agama memperhatikan dan mengerti realitas yang terjadi di masyarakat. Pada akhirnya, tokoh agama dituntut untuk bisa mengatasi rasa tertekan masyarakat dan mengubahnya menjadi semangat dan harapan. Kepercayaan tersebut membuat masyarakat merasa aman secara psikologis untuk terus berada di bawah hegemoni karisma tokoh agama. Dengan demikian, karisma seorang tokoh agama melahirkan hegemoni kekuasaannya atas masyarakat di semua bidang kehidupan masyarakat yang tidak saja terbatas pada agama melainkan juga merambah dalam rutinitas budaya yang ada dalam kehidupan mereka.

\section{Kontestasi Ideologi: Moderat Versus Radikalisme}

Ketokohan Guru Tua dan Ustaz Muda di tengah kehidupan masyarakat Desa Kayu Besi tidak dapat diragukan lagi. Mereka berdua selalu bersama bersinergi untuk memberikan bimbingan Islam kepada masyarakat. Menurut hemat penulis, memang sudah sepatutnya para tokoh agama memiliki hubungan yang baik antar tokoh agama yang lain. Mengingat bahwa tugas mereka sama yaitu bertujuan untuk memberikan kontribusi dan dedikasi guna menyelesaikan persoalan yang marak berkembang di tengah kehidupan masyarakat. Meskipun demikian, tidak dimungkiri bahwa setiap tokoh agama memiliki ideologi yang berbeda. Sehingga hal itu seringkali terjadinya kontestasi di antara mereka untuk mendapatkan legitimasi atas ideologi yang dimiliki dan dijalani. Begitu juga yang terjadi antara Guru Tua dan Ustaz Muda. 
Setelah penulis melakukan wawancara kepada beberapa kalangan masyarakat, maka didapati penjelasan bahwa pada awalnya hubungan Guru Tua dan Ustaz Muda sangat baik. Mereka sering duduk bersama dalam satu majelis ilmu untuk memberikan bimbingan Islam kepada masyarakat. Ustaz Muda pun awalnya dikenalkan oleh Guru Tua kepada masyarakat, bahwa Ustaz Muda merupakan alumni Pondok Pesantren Syaikhona Cholil Bangkalan, Madura, dan memiliki pemahaman agama yang baik. Sehingga Guru Tua menganjurkan agar masyarakat mempelajari ilmu agama kepadanya. Akan tetapi, sekarang mereka sudah tidak pernah lagi bersama. Perbedaan pendapat pun mulai tampak di antara keduanya. Namun masyarakat tidak mengetahui akar permasalahan yang terjadi di antara mereka. Dengan demikian, masyarakat pun kebingungan harus mengikuti ajaran yang mana.

Penulis melakukan penelusuran yang lebih lanjut, maka didapati penjelasan bahwa ketidakharmonisan hubungan Guru Tua dan Ustaz Muda berawal pada tahun 2012. Di mana Ustaz Fatur Rozi bergabung dengan organisasi FPI. Merasa berseberangan pendapat dengan FPI, maka Guru Tua lebih memilih untuk menghindar. Guru Tua sudah memberikan nasihat kepada Ustaz Muda untuk tidak bergabung dengan FPI dan lebih baik fokus dengan pondok pesantren yang dibangun. Akan tetapi nasihat Guru Tua tidak direspons oleh Ustaz Muda dan dirinya lebih memilih bergabung dengan FPI. Dirinya beralasan bahwa dengan masuk FPI maka penyampaian ajaran Islam lebih meluas.

Masuknya Ustaz Muda ke FPI, ternyata sudah dikhawatirkan oleh Guru Tua. Ustaz Muda sudah mulai menyampaikan ajaran Islam di tengah masyarakat dengan sangat keras. Menurut Guru Tua, hal itu setidaknya jangan terjadi di masyarakat Desa Kayu Besi, mengingat masyarakat tidak bisa diberikan hukum yang terlalu keras. Sebagai tokoh agama yang hidup bermasyarakat harus memperhatikan konteks yang terjadi di masyarakat. Demikian itu dilakukan agar ajaran yang disampaikan mudah dipahami dan dijalani oleh mereka.

Kontestasi ideologi terjadi antara Guru Tua dan Ustaz Muda bukan hanya secara tidak langsung, bahkan pernah terjadi secara langsung. Kejadian perbedaan pendapat pun terjadi ketika perayaan Idul Fitri pada tahun 2018, Ustaz Muda menyampaikan bahwa zakat fitrah ke rumah Guru Tua tidak sah. Masyarakat memberikan zakat ke rumah Guru Tua karena di rumah Guru Tua ada seorang kakek tua umurnya 102 tahun hidup sebatang kara. Kakek tersebut diurusi oleh Guru Tua. Namun, pada saat jam 02.00 dini hari (pagi hari raya) kakek tersebut meninggal dunia. Alhasil zakat tersebut menurut pendapat Ustaz Muda, pelaksanaannya tidak sah. Dengan dalih bahwa kakeknya sudah meninggal dunia. Meskipun demikian, terlihat sikap bijaksana Guru Tua. Dia menanggapi dengan tetap sopan dan tidak marah. Dirinya pun mengklarifikasi kepada masyarakat agar mereka merasa tenang. Setelah Guru Tua menjelaskan kepada masyarakat, maka tampak beberapa dari mereka menyahut bahwa mereka mengikhlaskan zakat yang telah diberikan. Urusan zakat itu diterima atau tidaknya, maka mereka pasrahkan kepada Allah SWT. Mendengar jawaban dari masyarakat tersebut, lantas membuat hati Guru Tua terasa lega. Guru Tua pun meminta agar masyarakat tetap tenang. Dia pun menjelaskan bahwa perbedaan pendapat adalah rahmat dari Allah SWT.

Selain itu, Ustaz Muda tidak hanya keras dalam memberikan fatwa kepada masyarakat, namun secara tindakan pun dirinya tidak segan-segan memperlihatkan aksi. Hal itu dilakukannya untuk menegakkan amar ma'ruf dan mencegah nahi munkar. Setelah penulis melakukan penelusuran, maka didapati penjelasan bahwa dalam memberikan bimbingan Islam, Ustaz Muda menyampaikan bahwa haram hukumnya mengundang pemusik dalam sebuah acara, seperti acara perkawinan, khitanan, dan lain sebagainya. Tidak hanya itu, keharaman tersebut juga diharamkan bagi mereka yang menghadirinya. Demikian itu tidak 
bisa ditoleransi lagi, karena sudah jelas keharamannya. Oleh sebab itu, Ustaz Muda tidak pernah ingin menghadiri kegiatan yang di dalamnya ada pemusik.

Pendapat Ustaz Muda tersebut tampak berseberangan dengan pendapat Guru Tua terkait permasalahan tersebut. Menurut Guru Tua, dalam ajaran Islam, pemaksaan terhadap keinginan orang lain tidak dibenarkan. Karena apabila tokoh agama terlalu keras pendapatnya, maka Islam tidak akan pernah eksis sampai saat ini. Hal tersebut dikarenakan ketakutan orang dalam memeluk agama. Guru Tua tidak menyoalkan permasalahan tersebut, karena dia beranggapan hal-hal tersebut sangat sensitif. Sehingga dirinya lebih memilih untuk mementingkan kemaslahatan masyarakat. Ketika diundang ke acara pernikahan seseorang yang di dalamnya ada pemusik, Guru Tua tidak pernah tidak hadir, terkecuali dirinya lagi sakit atau ada kegiatan di luar. Kehadiran Guru Tua ke dalam acara yang ada pemusik, menuai kritik dari Ustaz Muda. Meskipun demikian, Guru Tua tetap tidak menggubris hal tersebut. Ketika Guru Tua dimintai alasan mengapa dirinya tetap menghadiri kegiatan tersebut, maka argumentasinya bahwa dirinya pergi memenuhi undangan tuan rumah bukan pemusik. Oleh sebab itu, dia selalu menghadiri undangan tersebut guna menghormati orang yang memberi undangan.

Tidak hanya sampai di situ, ada sebuah kejadian yang berbentuk aksi nyata, hasil dari ideologi Ustaz Muda. Peristiwa tersebut terjadi pada acara perayaan 17 Agustus di Desa Kayu Besi. Pihak pemerintahan desa mengundang pemusik sebagai hiburan. Akan tetapi acara tersebut tidak berjalan dengan maksimal. Dari pihak Ustaz Muda memberikan peringatan kepada pemerintah desa untuk tidak mengundang pemusik, karena mengundang kemaksiatan. Namun, peringatan dari Ustaz Fatur Rozi tidak direspons oleh pemerintahan desa, sehingga mereka mengundang pemusik untuk menghibur masyarakat. Mendengar perihal tersebut, datang segerombolan anggota bimbingan Ustaz Muda yang berafiliasi FPI, LPI, dan MPI, membongkar panggung yang sudah ditata dengan rapi. Melihat hal tersebut, pihak pemerintahan desa datang ke kediaman Guru Tua untuk meminta arahan dan pendapatnya terkait kejadian tersebut. Pemerintahan desa berinisiatif untuk melaporkan hal tersebut ke pihak yang berwajib, akan tetapi inisiatif tersebut tidak disetujui oleh Guru Tua. Demikian itu dilakukan Guru Tua karena menghawatirkan keadaan istri Ustaz Muda yang baru melahirkan anak ke empatnya. Guru Tua meminta agar permasalahan tersebut bisa diselesaikan secara kekeluargaan. Permintaan Guru Tua pun disetujui pihak pemerintahan desa dan menyelesaikan perkara tersebut secara kekeluargaan. Sehingga titik temunya, kegiatan mengundang pemusik sebagai hiburan 17 Agustus untuk masyarakat dilaksanakan.

Dari serangkaian penjelasan di atas, maka dapat dipahami bahwa kontestasi ideologi antara Guru Tua dan Ustaz Muda adalah kontestasi antara pemahaman agama yang moderat dan radikal. Dalam hal ini, yang berpikir moderat adalah Guru Tua, sedangkan yang berpaham Islam radikal adalah Ustaz Muda. Demikian itu dapat diketahui bahwa istilah moderat setidaknya memiliki dua makna. Petama, selalu menghindari pengungkapan atau perilaku yang ekstrem. Kedua, memiliki kecenderungan ke arah dimensi atau jalan tengah. Menurut Muchlis M. Hanafi, paham moderat adalah metode berinteraksi, berperilaku, dan berpikir secara seimbang (tawazun) dalam menyikapi dua keadaan. Sehingga hal itu ditemukan perilaku yang sesuai dengan prinsip Islam dan tradisi masyarakat, yaitu seimbang dalam ibadah, akidah, dan akhlak. ${ }^{103}$ Oleh sebab itu, menelaah dari definisi

103 Muchlis M. Hanafi, Moderasi Islam: Menangkal Radikalisasi Berbasis Agama (Jakarta: Ikatan Alumni alAzhar dan Pusat Studi Al-Qur'an, 2013), 3 - 4. 
tersebut, menurut hemat penulis maka dapat dikatakan bahwa Guru Tua berideologi Islam moderat.

Alasan penulis menyebutkan bahwa Ustaz Muda berpaham radikal, karena merujuk pada makna radikalisme itu sendiri. Radikalisme merupakan suatu paham yang menginginkan adanya pergantian, penjebolan, dan perubahan terhadap suatu sistem di masyarakat. Pemahaman tersebut menginginkan perubahan total terhadap suatu kondisi atau semua aspek kehidupan masyarakat. ${ }^{104}$ Menurut Horace Kallen, radikalisme tersebut memiliki tiga kecenderungan. Pertama, merespons terhadap kondisi yang sedang berlangsung. Respons tersebut mucul dalam bentuk penolakan, evaluasi, bahkan perlawanan. Adapun masalah yang ditolak dapat berupa asumsi, ide, dan lembaga. Kedua, radikalisasi tidak berhenti pada upaya penolakan, melainkan selalu berupaya mengganti tatanan tersebut dalam bentuk tatanan lain. Ketiga, kuatnya keyakinan kaum radikalis terkait program atau ideologi yang mereka bawa. Sikap tersebut dibarengi penafian kebenaran dengan sistem lain yang akan diganti. ${ }^{105}$ Oleh sebab itu, dari penjelasan tersebut maka penulis berasumsi bahwa ideologi yang dimiliki oleh Ustaz Muda adalah berpaham radikal. Hal tersebut, juga sudah dapat ditebak karena dirinya berafiliasi FPI.

\section{Akhir kisah kontestasi antara Guru Tua dan Ustaz Muda}

Apabila merujuk pada definisi tokoh agama yang digagas oleh Nukhet A. Sandal yaitu tokoh agama adalah seorang pakar dan praktisi yang dituntut memiliki latar belakang pendidikan yang jelas, serta terlibat aktif dalam kegiatan masyarakat. Demikian itu dikarenakan selain tokoh agama dapat memberikan bimbingan kepada masyarakat. Mereka juga berpotensi menjerumuskan masyarakat kepada konflik dalam beragama.106 Maka setiap tokoh agama pasti memiliki corak yang berbeda, baik gaya, cara berpikir, dan strateginya dalam memberikan bimbingan Islam di tengah kehidupan masyarakat. Meskipun demikian, tidak dapat dimungkiri bahwa terkadang para tokoh agama melakukan kontestasi guna menunjukkan eksistensinya dan mendapatkan legitimasi dari masyarakat dengan caranya masing-masing. Begitulah kontestasi yang terjadi antara Guru Tua dan Ustaz Muda.

Terjadinya kontestasi antara Guru Tua dan Ustaz Muda dikarenakan keduanya ingin menunjukkan eksistensinya dalam memberikan bimbingan kepada masyarakat. Mereka juga memperebutkan pengakuan masyarakat atas dirinya. Pada saat mereka mendapatkan legitimasi dari masyarakat, otomatis pengikut mereka pun bertambah. Oleh sebab itu, ada rasa kebanggaan tersendiri bagi mereka jika pengikutnya semakin bertambah.

Guru Tua memiliki pengikut dari berbagai kalangan masyarakat, baik anak-anak, remaja, dan dewasa. Semua kalangan masyarakat tersebut menghormatinya. Guru Tua adalah sosok orang yang sangat disegani oleh masyarakat. Sifat yang baik dan sederhana, serta sikap yang bijaksana, membuat dirinya mendapatkan pengakuan dari masyarakat dari sejak muda sampai sekarang. Strategi Guru Tua mencari pengakuan dari masyarakat, tidak dipersiapkan secara sistematis. Namun hal itu, dibawanya mengalir dan disesuaikan konteks kehidupan bermasyarakat. Oleh sebab itu, Guru Tua memiliki peran yang sangat penting terhadap tatanan agama di Desa Kayu Besi, Kecamatan Puding Besar, Kabupaten Bangka, Provinsi Kepulauan Bangka Belitung.

104 Zuly Qadir, Radikalisme Agama di Indonesia (Yogyakarta: Pustaka Pelajar, 2014), 116.

105 Khamami Zada, Islam Radikal: Pergulatan Islam Garis Keras di Indonesia (Jakarta: Teraju, 2002), 15 - 16.

106 Nukhet A. Sandal, Religiuous Leaders and Conflict Transformation: Nothern Ireland and Beyond (United Kingdom: Cambridge University Press, 2017), 2. 
Contoh kongkret yang membuktikan bahwa Guru Tua mendapatkan legitimasi yang kuat dari kalangan masyarakat, yaitu ketika masuk di bulan Rabiul Awal. Sudah menjadi budaya masyarakat Desa Kayu Besi merayakan hari lahir Nabi Muhammad SAW atau dikenal dengan istilah mauludan yang dilakukan secara besar-besaran atau meriah setiap tahunnya. Namun, pada saat perekonomian masyarakat anjlok, maka banyak masyarakat tidak menyanggupi untuk merayakannya. Kebingungan yang luar biasa dirasakan masyarakat pada saat itu, terlebih lagi seorang pengkhotbah sangat menganjurkan untuk merayakannya, karena ganjaran pahalanya besar. Meskipun demikian, persoalan kebingungan tersebut disampaikan masyarakat kepada Guru Tua dan meminta pendapat darinya. Guru Tua pun menjelaskan bahwa bagi masyarakat yang merasa mampu mengerjakannya, maka dipersilahkan. Akan tetapi bagi masyarakat yang tidak mampu melaksanakannya, maka jangan dilaksanakan. Mendengar pendapat dari Guru Tua tersebut maka masyarakat pun merasa lega. Alhasil, perayaan mauludan yang biasanya meriah, akan tetapi pada saat itu dirayakan secara sederhana atau semampu masyarakat. Dari peristiwa tersebut, dapat dipahami bahwa legitimasi masyarakat atas ketokohan Guru Tua sangat kuat. Sehingga hal tersebut membuat mereka menyepakati setiap keputusan yang dilayangkan oleh Guru Tua.

Namun demikian itu, berbeda halnya dengan Ustaz Muda. Ketokohan Ustaz Muda awalnya terbangun karena Guru Tua. Ustaz Muda dikenalkan kepada masyarakat bahwa dirinya merupakan orang yang memiliki pemahaman keagamaan. Mendengar kabar tersebut, legitimasi masyarakat mulai didapatkan oleh Ustaz Muda. Banyak di kalangan masyarakat mempelajari ilmu agama kepadanya. Dari tahun ke tahun, pengikut Ustaz Muda pun mulai bertambah, mulai dari anak-anak sampai orang dewasa. Ketokohannya pun mulai dilirik oleh khalayak ramai. Terlebih dirinya membangun pondok pesantren dan menggandeng beberapa habib yang masyhur. Sehingga hal tersebut membuat namanya mulai bergaung.

Meskipun demikian, cukup disayangkan. Semakin besar gaungan nama Ustaz Muda dikenal masyarakat, ternyata membuat dirinya berimajinasi untuk memperluas kegiatan bimbingan Islamnya. Sehingga dirinya bergabung dengan organisasi FPI. Namanya pun bergaung di Bangka Belitung. Dirinya mulai sibuk diundang oleh masyarakat luar untuk memberikan bimbingan dan melakukan aksi dengan turun ke jalan. Akan tetapi kesibukannya tersebut ternyata menelantarkan pondok pesantren yang telah dirinya bangun. Sehingga waktunya tidak ada lagi untuk mengurusi pesantren tersebut, karena disibukkan kegiatan organisasi. Dari kejadian tersebut, legitimasi masyarakat kepadanya mulai redup atau berkurang.

Tidak sampai di situ, berkurangnya legitimasi masyarakat atas dirinya di samping tidak ada lagi waktu membimbing masyarakat dan mengurus pesantren, namun terlebih lagi sikapnya yang sering membuat kontroversi di kehidupan masyarakat. Sikapnya yang menunjukkan arogansi dalam berpendapat dan selalu merasa pendapatnya paling benar, terlebih beberapa kali memperlihatkan kontestasinya terhadap Guru Tua. Oleh sebab itu, satu per satu pengikut Ustaz Muda mulai hilang dan tempat bimbingannya pun tutup.

Walaupun Ustaz Muda merasakan bahwa legitimasi masyarakat berkurang kepadanya, tidak membuatnya berubah sikap. Dirinya pun semakin menunjukkan eksistensinya sebagai Ketua Umum DPP FPI Bangka Belitung. Namun perlu dipahami bahwa legitimasi masyarakat kepadanya hilang total terjadi pada pristiwa dirinya dan para anggota FPI menggerebek rumah tokoh agama yang diteladani masyarakat yaitu Guru Tua.

Peristiwa tersebut yaitu permasalahan politik 2018. Pertarungan yang boleh dikatakan sangat mencekam. Alkisah Guru Tua pergi ke acara seminar pelatihan khotib di kota Sungailiat, Kabupaten Bangka. Akan tetapi, tanpa sepengetahuannya di depan kediamannya dipasang foto Calon Presiden dan Calon Wakil Presiden nomor urut satu. Rumah Guru Tua 
memang strategis untuk dipasang sebuah spanduk. Namun perlu diketahui bahwa sebenarnya tidak hanya poster paslon 01 yang dipasang di sana. Akan tetapi pasangan 02 pun terlebih dahulu berada di rumahnya. Kemudian hal itu dilihat rombongan anggota bimbingan Ustaz Muda yang tergabung di FPI. Melihat hal tersebut kemudian mereka beramai-ramai datang ke rumah Guru Tua mencopot secara paksa spanduk tersebut, sedangkan saat itu Guru Tua tidak ada di rumah. Sepulangnya Guru Tua ke rumah, cerita tersebut sampai ke telinganya. Guru Tua pun hanya tersenyum dan menanggapi dengan biasa saja.

Pada saat ada acara di masjid, tampak Guru Tua duduk sopan di depan. Kemudian masalah tersebut dibicarakan di masjid. Masyarakat pun merasa heran. Kemudian giliran Guru Tua berbicara, ternyata Guru Tua hari itu cukup tegas mengatakan "Seumur hidup saya tidak pernah memperlihatkan diri untuk berpihak ke mana pun. Bahkan saya tidak pernah mengajak kalian untuk memilih salah satu calon. Siapa saja yang merusak pekarangan rumah saya dan membongkar paksa spanduk tersebut. Maka dari itu katakan pada ustaz, kiai, bahkan habib sekali pun, datang ke rumah saya. Biar saya ajarkan bagaimana caranya bersopan santun untuk hidup di masyarakat dan di Indonesia. Karena kita hidup di negeri yang menjunjung tinggi nilai demokrasi".

Dari gertakan Guru Tua tersebut, terlihat tidak ada satupun masyarakat yang berani dengan Guru Tua. Selesai acara beberapa orang masyarakat bergumam bahwa "baru hari ini saya melihat guru bersikap tegas seperti itu, namun memang wajar andaikan saja kita di posisinya maka mungkin sudah pertumpahan darah. Namun Guru Tua sangat sabar". Oleh sebab itu, dari peristiwa tersebut legitimasi masyarakat kepada Ustaz Muda spontanitas hilang. Sehingga dari kejadian tersebut, Ustaz Muda merasa sangat malu dan meminta maaf atas sikapnya terhadap Guru Tua. Alhasil, Guru Tua memberikan maaf atas peristiwa tersebut asal tidak diulangi di kemudian hari.

Kontestasi yang terjadi di antara Guru Tua dan Ustaz Muda juga dipengaruhi sikap politik keduanya. Setelah penulis mencoba menelusuri hal tersebut, dapat diketahui bahwa Guru Tua tidak pernah menampakkan pilihan politiknya di hadapan masyarakat. Bahkan, Guru Tua tidak pernah melakukan pemilihan alias golput. Hal itu dilakukannya karena menurutnya perpolitikan dapat membuat hubungan sesama saudara tidak harmonis. Menurutnya sikapnya untuk tidak memilih atau berpihak ke mana pun bukan berarti dirinya tidak menghormati pesta rakyat. Akan tetapi yang dia khawatirkan adalah dampak dari sikap politiknya. Oleh sebab itu, dirinya tidak ingin menampakkan sikap politiknya dengan berpihak ke mana pun.

Sikap politik Guru Tua berbeda dengan Ustaz Muda. Ustaz Muda sangat menampakkan keberpihakannya kepada para pemain politik. Bahkan, tidak jarang dirinya dijadikan corong untuk mengkampanyekannya. Dengan menjual ketenarannya sebagai ustaz, pengasuh pondok pesantren, ketua MPI, ketua FPI, dan tokoh agama yang memiliki pengaruh di Bangka Belitung untuk menyukseskan calon yang dipercayakan. Setelah penulis menelusuri lebih jauh, dapat penjelasan bahwa sikap politik Ustaz Muda tidak terlepas dari kepentingannya untuk mendapatkan bantuan dana dari para politikus untuk membesarkan pondok pesantren dan majelis yang dibangun. Hal itu diketahui dengan sigapnya dirinya menyebar proposal bantuan anggaran kepada setiap partai politik. Walaupun dirinya secara terang-terangan menentang beberapa partai politik yang dianggapnya sebagai antek-antek PKI, seperti Partai Demokrasi Indonesia (PDI).

Kontestasi yang terjadi antara Guru Tua dan Ustaz Muda pada akhirnya berakhir dengan dimenangkan Guru Tua. Guru Tua mendapatkan semakin banyaknya pengakuan dari masyarakat (pemuda, orang tua, dan pemerintah) atas ketokohannya. Sedangkan Ustaz 
Muda harus kehilangan legitimasi dari masyarakat dan para pemerintah, baik pemerintah kabupaten ataupun provinsi. Kehilangan legitimasi tersebut dirasakan oleh Ustaz Muda sampai sekarang.

Melihat legitimasi masyarakat sudah hilang kepada Ustaz Muda membuat dirinya merasa terpukul dan bersalah. Sehingga pada bulan Januari 2020, Ustaz Muda mengumumkan bahwa dirinya secara resmi keluar dari organisasi FPI dan memfokuskan dirinya pada perkembangan pondok pesantren. Alhasil, dari kontestasi tersebut membuat Ustaz Muda membangun kembali kepercayaan masyarakat atas dirinya. Oleh sebab itu, pada awal tahun 2020 dirinya membangun majelis taklim yang diberi nama Daarul Hijroh khusus untuk para remaja putri. Pada akhirnya, legitimasi masyarakat atas Ustaz Muda mulai dibangun kembali di tengah kehidupan masyarakat Desa Kayu Besi.

Kisah terjatuhnya legitimasi masyarakat kepada Ustaz Muda untuk memberikan bimbingan Islam, mungkin sama halnya atau persis dengan apa yang telah ditulis oleh James B. Hoesterey. ${ }^{107}$ Dalam artikel tersebut, dia megeksplorasi kosmopolitanisme profetik. Menurutnya kosmopolitanisme profetik, keduanya dinformasikan dan ditawarkan sebagai alternatif untuk diskusi global tentang psikologi dan diri, warga negara, penganut agama, bangsa dan umat. Kebangkitan Islam saat ini telah terfragmentasi bentuk tradisional otoritas keagamaan dan menghasilkan para tokoh baru kesalehan publik, di mana ajaran Islam disusun dan diperebutkan melalui warisan Nabi Muhammad SAW. Para tokoh tersebut memanfaatkan dan berdagang dengan modal simbolik dan ekonomi Islam, sains, dan teknologi media. Mereka menyulap cerita dan ucapan khusus tentang Nabi Muhammad SAW untuk membantu mempromosikan visi kewarganegaraan dan tugas sipil tertentu.

Dalam artkel tersebut, James B. Hoestorey menelaah ketokohan Abdullah Gymnastiar (Aa' Gym). Pada September 2004, Aa' Gym menggandeng beberapa tokoh agama terkemuka dan para politisi, mendeklarasikan gerakan sipil yang dinamakan Gema Nusa (Gerakan untuk Membangun Hati Nurani Bangsa). Dari gerakan tersebut popularitas nama Aa' Gym bergaung ke seluruh penjuru Indonesia. Data etnografi dalam artikel tersebut menggambarkan Aa' Gym di puncak kepopulerannya. Pada Desember 2006, kurang dari setahun setelah pelatihan Gema Nusa dijelaskan, legitimasi publik kepada Aa' Gym pun jatuh karena secara diam-diam menikah dengan wanita pengagumnya pada acara Gema Nusa dan menjadikan istri kedua. Merasa dikhianati, publik meluncurkan kampanye untuk memboikot khotbah dan seminar pelatihan yang digagas oleh Aa' Gym. Dalam beberapa tahun terakhir Aa' Gym telah kembali secara sederhana.

\section{Penutup}

Pertanyaan utama penelitian ini adalah bagaimana strategi Guru Tua dan Ustaz Muda dalam memberikan bimbingan Islam kepada masyarakat pedesaan di Bangka Belitung, bagaimana kontestasi, dan mengapa kontestasi di antara keduanya bisa terjadi. Berdasarkan penjelasan, data dan temuan yang ditemukan dalam penelitian ini, maka ada beberapa kesimpulan yang dapat ditarik, sebagai berikut:

Dalam pemberian bimbingan Islam kepada masyarakat, Guru Tua tidak hanya sebatas menyampaikan materi. Namun dia juga menyelesaikan pelbagai permasalahan yang dihadapi oleh masyarakat, baik masalah pribadi, keluarga, sosial, dan agama. Layanan bimbingan Guru Tua dalam hal ini adakalanya berbentuk bimbingan individu dan ada pula bentuk bimbingan kelompok. Kehadiran masyarakat ke kediaman Guru Tua untuk meminta

107 James B. Hoesterey, "Prophetic Cosmopolitanism: Islam, Pop Psycology, and Civic Virtue in Indonesia", City and Society: American Anthropoligical Association, Vol. 24, Issue 1, (2012), 38 - 61. 
bimbingan dan solusi atas permasalahan yang mereka hadapi dikategorikan sebagai layanan bimbingan individu. Sedangkan bimbingan kelompok dilakukannya juga diminta masyarakat untuk memberikan bimbingan Islam dan menyelesaikan permasalahan, demikian itu dilaksanakan dengan cara berkelompok. Di mana, Guru Tua memberikan materi tugas dan materi bebas. Materi tugas dimaksudkan adalah materi yang disampaikan oleh Guru Tua dan setelah materi tersebut tersampaikan, mereka pun membahas materi tersebut secara bersama. Adapun materi bebas dimaksudkan adalah materi yang membahas permasalahan anggota bimbingan. Materi tersebut merupakan materi permasalahan yang dihadapi oleh mereka dan diselesaikan secara bersama. Oleh sebab itu, bimbingan semacam ini dinamakan bimbingan kelompok. Tidak hanya itu, Guru Tua juga sering dimintai masyarakat untuk mengisi ceramah dan doa di acara-acara keagamaan, seperti khitanan, perkawinan, mauludan, tahlilan, dan lain sebagainya.

Sedangkan bimbingan Islam yang dilaksanakan oleh Ustaz Muda kepada masyarakat adalah bimbingan yang hanya sebatas pemberian pemahaman tentang ajaran Islam. Dalam bimbingan tersebut, Ustaz Muda tidak menyelesaikan permasalahan yang dihadapi oleh masyarakat. Kegiatan bimbingan seperti hal itu, dapat dikenal dengan istilah pengajian atau majelis taklim yang menuntut pembimbing lebih aktif dalam menyampaikan materi keislaman. Setelah Ustaz Muda menyampaikan materi bimbingan, maka langsung ditutup dengan pembacaan doa. Sehingga demikian itu, tidak terlihat terjadinya interaksi antara anggota bimbingan dan Ustaz Muda. Pada kesempatan yang lain, Ustaz Muda juga sering diundang masyarakat untuk memberikan ceramah agama di kegiatan-kegiatan keagamaan, seperti yasinan, tahlilan, tasyakuran, mauludan, dan lain sebagainya. Tampilnya Ustaz Muda sebagai pembimbing dalam hal ini menurut hemat penulis adalah upaya untuk merealisasikan fungsi dan tanggung jawabnya yang dianggap sebagai tokoh agama guna memberikan pemahaman keislaman kepada masyarakat.

Guru Tua dan Ustaz Muda adalah tokoh agama yang dipercayai masyarakat untuk memberikan bimbingan Islam kepada mereka. Hubungan mereka berdua, awalnya harmonis. Keduanya sering kali terlihat bersama dalam setiap kegiatan keagamaan yang dilaksanakan masyarakat. Namun beberapa tahun kemudian, keharmonisan tersebut terlihat pudar. Ketidakharmonisan tersebut tampak ketika keduanya tidak pernah bersama lagi. Hal itu dikarenakan perbedaan prinsip. Dari perbedaan tersebut terlihat keduanya saling berkontestasi untuk memperebutkan legitimasi masyarakat atas eksistensi mereka. Kontestasi tersebut terjadi secara tampak. Adapun konfigurasi dari kontestasi yang mereka lakukan, menurut hemat penulis ada tiga hal. Pertama, kontestasi terkait kealiman. Kontestasi ini terlihat keduanya saling menunjukkan kealimannya dengan caranya masingmasing. Kedua, kontestasi kuasa. Otoritas keagamaan Guru Tua adalah bentuk pengakuan masyarakat atas dirinya. Hal tersebut dapat dikatakan bahwa Guru Tua memiliki otoritas karismatik. Sedangkan Ustaz Muda membangun otoritasnya dengan bergabung pada beberapa organisasi, seperti FPI, MPI, dan membangun beberapa majelis taklim. Dalam hal ini, otoritas yang dimiliki Ustaz Muda adalah otoritas legal. Ketiga, kontestasi ideologi. Pada kontestasi ini, keduanya saling bertarung dengan mempertahankan ideologinya masingmasing. Guru Tua yang lebih mencari jalan tengah dapat disebut memiliki ideologi moderat. Sedangkan, Ustaz Muda dalam hal ini selalu menunjukkan pendapat yang dapat dikatakan keras. Terlebih dirinya berafiliasi dengan FPI. Oleh sebab itu, dapat dipahami dan sikatakan bahwa ideologi Ustaz Muda adalah berpaham radikal.

Kontestasi antara Guru Tua dan Ustaz Muda berawal dari pada bergabungnya Ustaz Muda dengan organisasi FPI pada tahun 2012. Guru Tua sudah memberikan nasihat agar Ustaz Muda tidak bergabung dengan organisasi tersebut. Hal tersebut dilakukan Guru Tua karena 
mengkhawatirkan nasib pondok pesantren yang sudah dibangun Ustaz Muda. Akan tetapi nasihat Guru Tua tersebut tidak digubris oleh Ustaz Muda, sehingga dirinya tetap memilih bergabung dengan FPI. Melihat hal tersebut, Guru Tua akhirnya memilih menghindar, karena berbeda pola pikir dengan organisasi tersebut. Setelah bergabungnya Ustaz Muda ke FPI, maka benarlah apa yang dikhawatirkan Guru Tua. Alhasil pondok pesantren yang dibangun Ustaz Muda tidak terurus dan kegiatan bimbingan kepada masyarakat pun terpaksa ditutup. Demikian itu, dikarenakan Ustaz Muda disibukkan dengan kegiatan organisasi. Oleh sebab itu, pertarungan antara Guru Tua dan Ustaz Muda pun terjadi di tengah kehidupan masyarakat. Guru Tua yang memiliki pengikut terbanyak semakin banyak. Sedangkan Ustaz Muda dari banyak semakin sedikit. Mengetahui keadaan tersebut, pada akhirnya Ustaz Muda memilih keluar dari organisasi FPI pada tahun 2020. Dengan alasan bahwa dirinya ingin fokus mengurus pondok pesantren yang telah dibangun di Desa Kayu Besi, Kecamatan Puding Besar, Kabupaten Bangka. Dengan demikian, akhirnya Ustaz Muda saat ini, membangun kepercayaan masyarakat atas dirinya dan otoritasnya dengan membangun kembali majelis taklim yang diberi nama Daarul Hijroh. Majelis tersebut dibentuk khusus untuk para remaja putri. 


\section{DAFTAR PUSTAKA}

\section{Sumber Buku}

Abdullah, Taufik. Agama dan Perubahan Sosial. Jakarta: CV Rajawali, 1983.

Bintaro, R. Dalam Interaksi Desa-Kota dan Permasalahannya. Jakarta: Ghalia Indonesia, 1989.

Burn, Tom R. Manusia, Keputusan, Masyarakat. Jakarta: PT Pranadya Paramita Dandjaja, 1987.

Bourdieu, Pierre. Arena Produksi Kultural: Sebuah Kajian Sosiologi Budaya, terj. Yudi Santosa. Jakarta: Kreasi Wacana, 2015.

Dhofier, Zamakhsyari. Tradisi Pesantren: Studi Tentang Pandangan Hidup Kyai. Jakarta: LP3ES, 1982.

Ekaswati, Weny. Kepercayaan Masyarakat Terhadap Kyai (Yogyakarta: Fakultas Psikologi Universitas Islam Indonesia, 2006.

Fadli, Moh., dkk., Pembentukan Peraturan Desa Partisipatif: Head to A Good Village Governance. Malang: UB Press, 2011.

Gallie, Walter Bryce. Arts as an Essentianlly Contested Concepts': The Philosophical Quarterly. New York: Schocken Books, 1956.

Hanafi, Muchlis M. Moderasi Islam: Menangkal Radikalisasi Berbasis Agama. Jakarta: Ikatan Alumni al-Azhar dan Pusat Studi Al-Qur'an, 2013.

Hasan, Noorhaidi dan Anas Aijudin, "Islam dan Kekuasaan: Menakar Pandangan Ulama Surakarta terhadap Negara-Bangsa", Ibnu Burdah, Najib Kailani, dan Munirul Ikhwan (ed.), Ulama, Politik, dan Narasi Kebangsaan: Fragmentasi Otoritas Keagamaan di kotakota Indonesia. Yogyakarta: PusPIDep, 2019.

Hoesterey, James B. "Prophetic Cosmopolitanism: Islam, Pop Psycology, and Civic Virtue in Indonesia", City and Society: American Anthropoligical Association, Vol. 24, Issue 1, (2012).

Kartono, Kartini. Pemimpin dan Kepemimpinan, Apakah Pemimpinan Abnormal Itu? Jakarta: Raja Grafindo Persada, 1998.

Lubis, Saiful Akhyar. Konseling Islami: Kiai dan Pesantren. Yogyakarta: eLSAQ Press, 2007.

Musnamar, Tohari. Dasar-Dasar Konseptual Bimbingan dan Konseling Islami. Yogyakarta: UII Press, 1992.

Nabi, Malik Bin. Membangun Dunia Baru Islam. Bandung: Mizan, 1994.

Nizar, Syamsul. Sejarah Sosial dan Dinamika Intelektual. Jakarta: Kencana Prenada Media Group, 2013.

Pusat Bahasa Departemen Pendidikan Nasional RI, Kamus Bahasa Indonesia (KBBI). Jakarta: Balai Pustaka, 2008.

Qadir, Zuly. Radikalisme Agama di Indonesia. Yogyakarta: Pustaka Pelajar, 2014.

Ro'fah dan Eva Latipah, "Strategi Bertahan dan Aktivitas Pendidikan Islam di Kawasan Minoritas", kontributor, Ulama dan Negara-Bangsa: Membaca Masa Depan Islam Politik di Indonesia. Yogyakarta: PusPIDeP, 2019.

Ronald. Tokoh Agama dalam Masyarakat. Jakarta: Rineka Cipta, 2004.

Sandal, Nukhet A. Religious Leaders and Conflict Transformation: Northern Ireland and Beyond. United Kingdom: Cambridge University Press, 2017.

Sardar, Ziauddin. Tantangan Dunia Islam Abad 21: Menjangkau Informasi. Bandung: Mizan, 1998.

Shalahuddin, Anas. Bimbingan dan Konseling. Bandung: CV Pustaka Setia. 2010.

Soekanto, Soerjono. Sosiologi Suatu pengantar. Jakarta: Rajawali, 2009.

Stompka, Pior. Sosiologi Perubahan Sosial. Jakarta: Penanda Media Group, 2008. 
Sutoyo, Anwar. Bimbingan dan Konseling Islami: Teori dan Praktik. Yogyakarta: Pustaka Pelajar, 2013.

Weber, M. The Theory of Social and Economic Organization, Transleted by Talcott Parson. New York: The Fress Press, 1966.

Widjaja, H.A.W. Pemerintahan Desa/Marga. Jakarta: PT. Raja Grafindo Persada 2003.

Wiener, Antje. A Theory of Contestation. New York: Springer, 2014.

Willis, Sofyan S. Konseling Individual: Teori dan Praktek. Bandung: Alfabeta, 2007.

Zada, Khamami. Islam Radikal: Pergulatan Islam Garis Keras di Indonesia. Jakarta: Teraju, 2002.

\section{Sumber Artikel}

Ahnaf, M. Iqbal dan Danielle N. Lussier, "Religious Leaders and Elections in the Polarizing Context of Indonesia", Jurnal Humaniora, Vol. 31, No. 3 (October 2019), 227 - 237.

Ali, Yusuf Faisal. "Upaya Tokoh Agama dalam Mengembangkan Sikap Toleransi Antarumat Beragama", UCEJ: Untirta Civic Education Journal, Vol. 2, No. 1 (2017).

Amrullah, Bahaudin. 2015, "Peran Kiai dalam Politik: Studi Atas Pemenangan Calon Legislatif oleh KH. Arsyad Bushoiri dalam Perspektif Hukum Islam”, Skripsi: IAIN Tulungagung, dalam http://repo.iain-tulungagung.ac.id/2746/. diakses 23 Desember 2019.

Anshel, Mark H. dan Mitchell Smith, "The Role of Religious in Promoting Healty Habits in Religious Institutions", Journal of Religioun and Health, Springer Science and Bussines Media New York, Vol. 52, No. 1 (Marc 2013).

Baharudin dan Moh. Nasikin, "Peran Sosial Tokoh Agama dalam Merawat Kerukunan Beragama di Lombok Barat", Intutional Repository, Lembaga Penelitian dan Pengabdian Masyarakat, UIN Mataram, (Juli 2018).

Baihaqi, Muhammad Adib. "Peran Tokoh Agama dalam Menjaga Kerukunan Antar Umat Beragama: Komunikasi Kelompok pada Dusun Thekelan, Desa Batur, Kecamatan Getasan, Kabupaten Semarang", dalam http://erepository.perpus.iainsalatiga.ac.id/4402/1/SKRIPSI\% 20LENGKAP\%20ADIB\%20BAIHAQI\%20B.pdf, diakses 12 Desember 2019.

Barnes, Douglas F. "Charisma and Religious Leadership: An Historical Analysis", SOURCE: Journal for Scientific Study of Religion, University of Illinois Urbana-Champaign, Vol. 17, No. 1 (Maret 2013), 1 - 18.

Chaplain, Jhon L. Kallerson. 2014, "National Strategy for Religious Leader Engagements: Interagency Challenges Supporting Combatant Commands", dalam https://www.iwp.edu/national-strategy-for-religious-leader-engagementsinteragency-challenges-supporting-combatant-comma nds-2/. diakses 23 Desember 2019.

Cheong, Pauline Hope. "Religious Leaders, Mediated Authority, and Social Change", Routledge: Journal of Applied Communication Research, Vol. 39, No. 4 (November 2011), $452-454$.

Epley, Jennifer L. “Weber's Theory of Charismatic Leadership: The Case of Muslim Leaders in Contemporary Indonesian Politics", International Journal of Humanities and Social Science, Vol. 5, No. 7, (July 2015).

Fauzi, "The Perception of Religious Leaders in Maintaining the Harmonization in Aceh: An Analysis of Siyasah Syar'iyyah", Journal, Universitas Muhammadiyah Metro, Vol 1, No. 2 (June 2017), 18 - 33.

Gemilang, Kemas Muhammad. 2015, "Peran Tokoh Agama dalam Pembentukan Keluarga Sakinah di Kelurahan Kricak, Kecamatan Tegalrejo, Kota Yogyakarta", Skripsi, UIN 
Sunan Kalijaga Yogyakarta, dalam http://digilib.uin-suka.ac.id/17177/. diakses 13 Desember 2019.

Haider, Huma. "Religious Leaders and the Prevention of Electoral Violence", GSDRC Helpdesk Research Report 1366, University of Birmingham, (May 2016).

Hannan, Abd. "Agama, Kekerasan, dan Kontestasi Politik Elektoral: Penggunaan Simbol Keagamaan Kiai dan Kekuasaan Blater dalam Pertarungan Politik Lokal Madura", Jurnal Sosiologi Agama, Fakultas Ushuluddin dan Pemikiran Islam UIN Sunan Kalijaga Yogyakarta, Vol. 12, No. 2 (2018).

Hanaviah, Julsyaf. "Komunikasi Lintas Tokoh Agama dalam Memelihara Kerukunan Umat Beragama: Studi pada Forum Kerukunan Umat Beragama Kabupaten Pesawaran", dalam http://repository.radenintan.ac.id/4493/1/ SKRIPSI.pdf, diakses 13 Desember 2019.

Hartini, "Pandangan Tokoh Agama dan Budaya Masyarakat terhadap Pemakaian Alat Kontrasepsi", EGALITA: Jurnal Kesetaraan dan Keadilan Gender, Vol. 6, No. 1, (2011) dalam http://ejournal.uin-malang.ac.id/index.php/egalita/article/view/2120 diakses 24 Desember 2019.

Hayati, Sofia. 2017, "Kontestasi Ruang Publik: Studi Identitas Kampung Berlabel Agama di Sengkan, Depok, Sleman", Tesis: UIN Sunan Kalijaga Yogyakarta, dalam http://digilib.uin-suka.ac.id/24876/. diakses 23 Desember 2019.

Initiatif, Health Policy. 2013, "Engaging Religious Leaders in the Response to HIV and AIDS in Tanzania", dalam https://www.kebijakanaidsindonesia.net/id/component/j downloads/send/4-policy-brief/151-engaging-religious-leaders-in-the-response-tohiv-and-aids-in-tanzania diakses 24 Desember 2019.

Ismutadi. 2018, "Penerapan Etika Islam dalam Pembangunan Masyarakat: Studi Kepemimpinan Tokoh Agama di Desa Bandar Agung", dalam http://repository.radenintan.ac.id/3416/1/Ismutadi.pdf, diakses 13 Desember 2019.

Jamil, Fahrur Rozi. 2010, "Kharisma Tokoh dan Kekuasaan Politik: Studi Kasus RKH Fuad Amin Imron dalam Pilkada Bangkalan tahun 2008", Skripsi: UIN Sunan Kalijaga Yogyakarta, dalam http://digilib.uin-suka.ac.id/4044/ diakses 24 Desember 2019.

Karim, Khairulnizam Mat, dkk., "Role of Religious Leader in Interfaith Dialogue towards Conflict Resolution: An Islamic Perspective", International Journal of Education and Research, Vol. 2, No. 6 (June 2014), 77 - 88.

Khatimah, Khusnul. 2015, "Peran Tokoh Agama dalam Pengembangan Sosial Agama di Banyumas: Studi Historis Sosiologis Tokoh Agama Abad 21", dalam http://repository.iainpurwokerto.ac.id/345/1/khusnul\%20khotimah_PERAN\%20T0 KOH\%20AGAMA\%20DALAM\%20PENGEMBANGAN\%20SOSIAL\%20AGAMA.pdf., diakses 12 Desember 2019.

Mahadi, Ujang. 2015, "Komunikasi Politik Kiai pada Kampanye Pemilu", ADDIN: Media Dialektika Ilmu Islam, IAIN Kudus, Vol. 9, No. 2, (2015).

Makin, Al. "Not a Religious State: A Study of Three Indonesian Religious Leaders on Relation of State and Religion", Journal Indonesia and the Malay World, Volume 46, 2018 (Published Online: 11 Oct 2017), 95 - 116.

Minan, Khoirul. 2015, "Sinergi Local Strongmen: Pengusaha dan Tokoh Agama dalam Pemilihan Legislatif 2014 di Demak", Tesis: UIN Sunan Kalijaga Yogyakarta, dalam http://digilib.uin-suka.ac.id/16848/. diakses 23 Desember 2019.

Nuha, Ulin. "Peran Politik Kiai dalam Proses Politik di Partai Politik: Studi Kasus Peran KH. A. Haris Shodaqoh di Partai Persatuan Pembangunan", dalam 
https://media.neliti.com/media/publications/160785-ID-peran-politik-kiai-dalamproses-politik.pdf diakses 23 Desember 2019.

Nurjannah, Siti. 2017, "Peran Tokoh Agama dalam Membina Kegiatan Keagamaan Remaja Islam Masjid (Risma) di Desa Sritejo, Kencono, Kota Gajah Lampung Tengah", Tesis: IAIN Metro, dalam http://repository.metrouniv.ac.id/id/eprint/1738/, diakses 24 Desember 2019.

Piyantoro. 2017, "Peran Tokoh Agama dalam Merajut Pluralitas: Studi Kasus Tokoh Agama Islam Kecamatan Kartasura", dalam http://eprints.ums.ac.id/55794/, diakses 12 Desember 2019.

Putra, Ferdian Ardani dan Finish Rimbi Kawindra, "Komunikasi Tokoh Agama dalam Meredam Konflik Antar Umat Beragama: Studi Agama Islam, Hindu, dan Kristen di Kec. Senduro, Kab. Lumajang", Prosiding SNasPPM, Vol. 3, No. 1 (2018), 291 - 296.

Rahmawanto, Sulis. 2016, "Peran Tokoh Agama dalam Mewujudkan Keteraturan Masyarakat", dalam https://www.researchgate.net/publication/330660605_ PERAN_TOKOH_ AGAMA_DALAM_MEWUJUDKAN_KETERATURAN_MASYARAKAT, diakses 13 Desember 2019.

Sakdan, Ibnu. 2017, "Optimalisasi Peran Tokoh Agama dalam Meningkatkan Kesadaran Beragama Masyarakat di Kecamatan Kuala, Kabupaten Nagan Raya", Skripsi: Fakultas Dakwah dan Komunikasi UIN Ar-Raniry, dalam https://repository.arraniry.ac.id/329/, diakses 12 Desember 2019.

Siregar, Ferry Mumamadsyah., dkk., "Religious Leader and Charismatic Leadership in Indonesia: The Role of Kyai in Pesantren in Java", KAWISTARA: Jurnal Ilmiah Sosial dan Humaniora, Vol. 3, No. 2 (Agustus 2013), 117 - 226.

Sofianto, Arif. "Peran Agama Terhadap Perilaku Pemilih dalam Pemilu Legislatif 2014 di Jawa Tengah", Analisa Journal of Social Science and Religion, Vol. 22, No. 02 (Desember 2015), $161-172$.

Supartini. 2018, "Peran Tokoh Agama dalam Meningkatkan Sikap Keberagamaan Masyarakat di Dusun Pucung, Desa Sendang, Ngrayun, Ponorogo", dalam http://etheses.iainponorogo.ac.id/4399/1/pdfjoiner.pdf. diakses 12 Desember 2019.

Sulistyanto, Widayat. 2007, "Peranan Tokoh Agama dalam Perubahan Sosial Komunitas Pemulung di Kampung Sidomulyo, Kecamatan Tegalrejo Kodya, Yogyakarta:, Skripsi: UIN Sunan Kalijaga Togyakarta, dalam http://digilib.uin-suka.ac.id/36136/ diakses 23 Desember 2019.

Suprapto, "Religious Leaders and Peace Building: The Role of Tuan Guru and Pedanda in Conflict Resolution in Lombok-Indonesia", Al-Jami’ah: Journal of Islamic Studies, Vol. 53, No. 1 (2015), $225-250$.

Supriyanto. 2016, "Peran Tokoh Agama dalam Dinamika Pembangunan Masyarakat di Desa Ketanonageng Kecamatan Sragi Kabupaten Pekalongan", dalam https://lib.unnes.ac.id/27468/ diakses 13 Desember 2019.

Toweren, Karimi. 2018, "Peran Tokoh Agama dalam Peningkatan Pemahaman Agama Masyarakat Kampung Toweren Aceh Tengah", DAYAH: Journal of Islamic Education, UIN Ar-Raniry, Vol. 1, No. 2, 2018, 258 - 272.

\section{Wawancara dan Observasi}

Observasi pada tanggal 15 - 18 Desember 2019.

Observasi pada tanggal 13 - 17 Desember 2019.

Wawancara kepada beberapa masyarakat Desa Kayu Besi, 12 - 18 Desember 2019. 
Zainab, Wawancara, Kediamannya di Desa Kayu Besi, Kecamatan Puding Besar, Kabupaten Bangka, 23 Desember 2019.

Zaliha, Wawancara, Kediamannya di Desa Kayu Besi, Kecamatan Puding Besar, Kabupaten Bangka, 26 Desember 2019.

Guru Tua, Wawancara, di Kediamannya, Desa Kayu Besi, Kecamatan Puding Besar, Kabupaten Bangka, 23 Desember 2019.

Observasi ke Kediaman Guru Tua di Desa Kayu Besi, Kecamatan Puding Besar, Kabupaten Bangka, 23 Desember 2019 - 20 Januari 2020.

Ustaz Muda, Wawancara, Kediamannya di Desa Kayu Besi, Kecamatan Puding Besar, Kabupaten Bangka, 27 Desember 2019.

Muhimmah, Wawancara, Kediamannya di Desa Kayu Besi, Kecamatan Puding Besar, Kabupaten Bangka, 28 Desember 2019.

Kuris, Tokoh Masyarakat, Wawancara, kediamannya di Desa Kayu Besi, 19 Januari 2020.

Solnah, warga Desa Kayu Besi, Wawancara, 09 Januari 2020.

Kuris, Tokoh Masyarakat, Wawancara, Kediamannya di Desa Kayu Besi, 19 Januari 2020. 